Aus dem Department für Nutztierwissenschaften Abteilung Molekularbiologie der Nutztiere und molekulare Diagnostik und Tierärztliches Institut

\title{
Molekulargenetische Untersuchungen zu Augenerkrankungen beim Holstein Friesian Rind
}

\author{
Dissertation \\ zur Erlangung des Doktorgrades \\ der Fakultät für Agrarwissenschaften \\ der Georg-August-Universität Göttingen
}

vorgelegt von

Anne Katrin Hollmann

geboren in Ochtrup

Göttingen, Mai 2017 
D7

1. Referent: Prof. Prof. h.c. Dr. Dr. Bertram Brenig

2. Korreferent: apl. Prof. Dr. Ekkehard Schütz

Tag der mündlichen Prüfung: 05. Juli 2017 
Meiner Familie 


\section{Inhaltsverzeichnis}

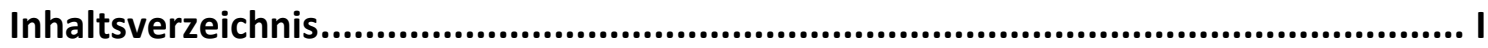

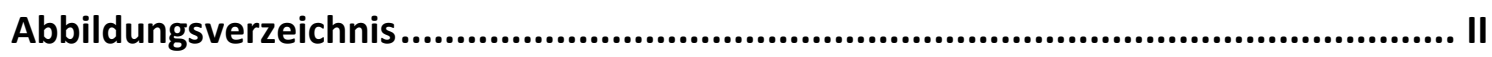

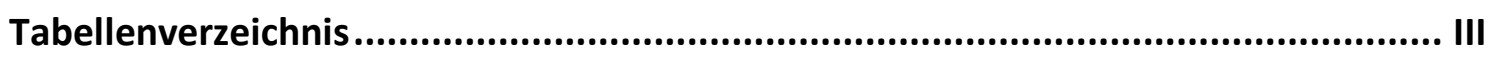

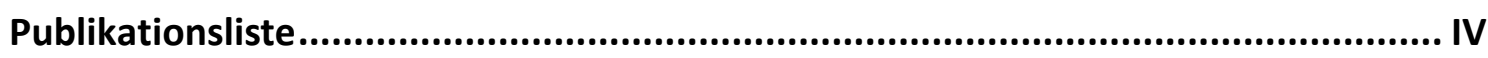

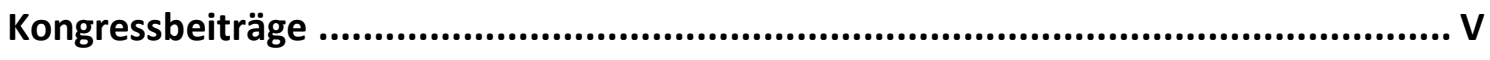

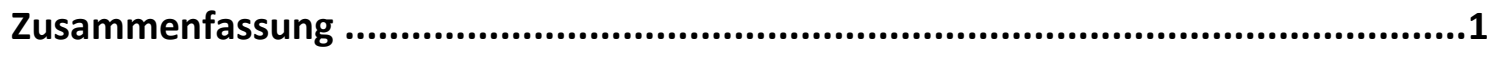

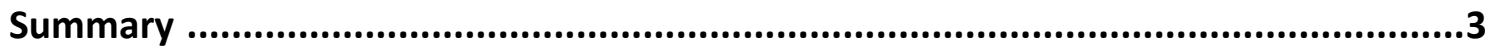

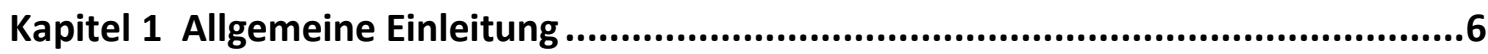

1.1 Anatomie und Embryologie von Linse und Iris...................................... 6

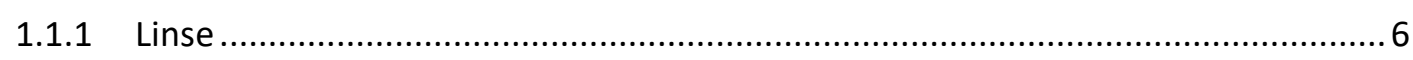

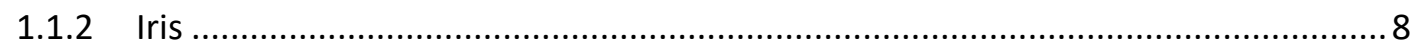

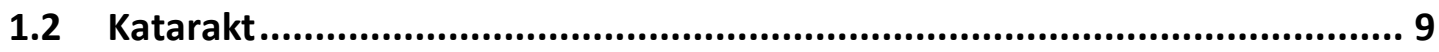

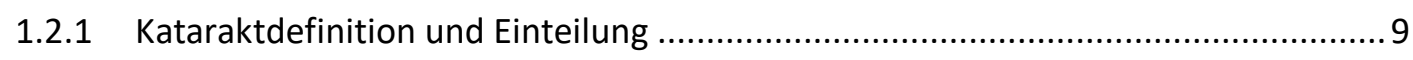

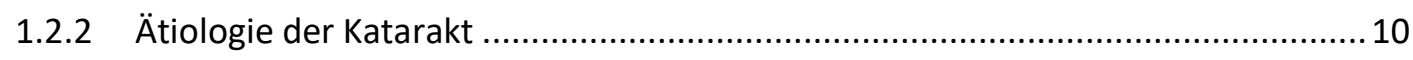

1.2.3 Auftreten von Katarakt beim Rind............................................................... 12

1.3 Irishypopigmentierung und Heterochromia iridis ....................................14

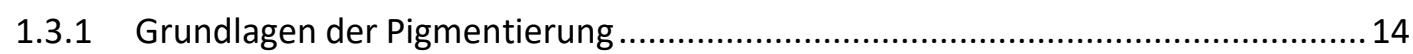

1.3.2 Irishypopigmentierung und Heterochromia iridis bei Mensch und Säugetieren ... 15

1.3.3 Phänotypische Ausprägung von Irisheterochromie und Irishypopigmentierung

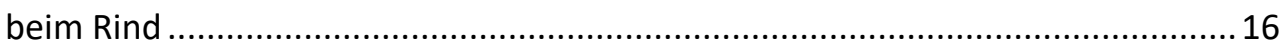

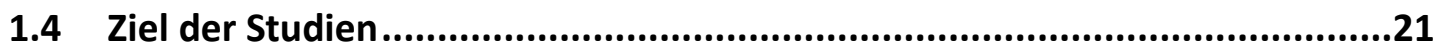

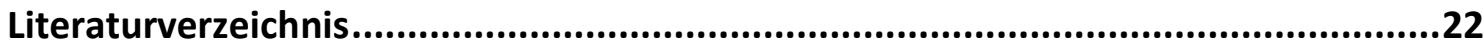

Kapitel 2 Morgagnian cataract resulting from a naturally occurring nonsense mutation elucidates a role of CPAMD8 in mammalian lens development..31

Kapitel 3 A genome-wide association study reveals a locus for bilateral iridal hypopigmentation in Holstein Friesian cattle .........................................66

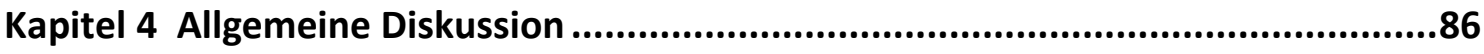

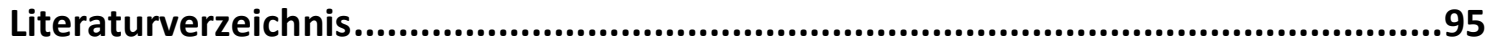

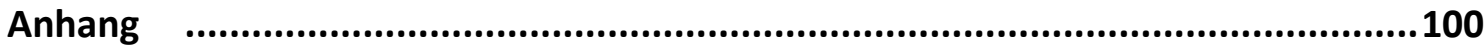




\section{Abbildungsverzeichnis}

\section{Kapitel 2}

Fig 1

Congenital cataract in Red Holstein Friesian cattle. . .35

Fig 2 Origin and transmission of cataract in Red Holstein Friesian cattle....... 37

Fig 3 Results of genome-wide association study (GWAS) using SNP data of 26 cases and 88 Holstein control animals..................................................39

Fig 4 Loss of CPAMD8 expression in cataract cases.

\section{Kapitel 3}

Fig 1 Phenotypic appearance of iridal hypopigmentation. 73

Fig 2 Histological cross section through the ciliary zone of the left ventral iris near the collarette with characteristic Fuchs' crypts. . .75

Fig 3 Manhattan plot of $-\log _{10}(p)$-values for SNPs by genomic location (NCBI UMD3.1.1) .76 


\section{Tabellenverzeichnis}

\section{Kapitel 1}

Tabelle 1 Zusammenfassung der beobachteten Irispigmentierungsveränderungen bei verschiedenen Rinderrassen.

\section{Kapitel 2}

Table 1 Detection of CPAMD8 g.5995966C $>$ T in different cattle breeds

Table 2 Tissue samples for RNA analyses of CPAMD8, including ddPCR results and RNA integrity number (RIN) from RNA quality measurement using RNA 6000 Pico Kit (Agilent Technologies, Waldbronn, Germany).

\section{Kapitel 3}

Table 1

Genotypic dependences of iridal hypopigmentation. .77

Table 2 Allelic dependences of iridal hypopigmentation. . .77

Table 3 Haplotype association analysis for markers flanking BTB-00352779......78 


\section{Publikationsliste}

Teile dieser Arbeit wurden bereits in Fachzeitschriften veröffentlicht:

Hollmann AK, Dammann I, Wemheuer WM, Wemheuer WE, Chilla A, Tipold A, SchulzSchaeffer WJ, Beck J, Schütz E \& Brenig B (2017). Morgagnian cataract resulting from a naturally occurring nonsense mutation elucidates a role of CPAMD8 in mammalian lens development. PLoS ONE 12(7): e0180665. DOI: 10.1371/journal.pone.0180665.

Hollmann AK, Bleyer M, Tipold A, Nessler JN, Wemheuer WE, Schütz E \& Brenig B (2017). A Genome-Wide Association Study Reveals a Locus for Bilateral Iridal Hypopigmentation in Holstein Friesian Cattle. BMC Genet 18, 30. DOI: 10.1186/s12863-017-0496-4. 


\section{Kongressbeiträge}

A. Hollmann, J. Beck, W. Wemheuer, G. von Gadow, T. Leeb, E. Schütz, B. Brenig (2012): Molekulargenetische Untersuchungen zur Kataraktentstehung beim Holstein Friesian. Vortragstagung der DGfZ und GfT am 12./13. September 2012 in Halle/Saale.

Anne K. Hollmann, Martina Bleyer, Andrea Tipold, Jasmin N. Neßler, Wilhelm E. Wemheuer, Ekkehard Schütz, Bertram Brenig (2016): Untersuchungen zur Irishypopigmentierung beim Holstein Friesian Rind. Vortragstagung der DGfZ und GfT am 20./21. September 2016 in Hannover.

Anne K Hollmann, Wilhelm E Wemheuer, Julia Beck, Bertram Brenig, Ekkehard Schütz (2016): Congenital cataract formation in Holstein Friesian cattle. Poster and Book of Abstracts. 35th International Society for Animal Genetics (ISAG) Conference, 23. - 27. Juli 2016, Salt Lake City, Utah, USA.

Anne K. Hollmann, Martina Bleyer, Andrea Tipold, Jasmin N. Neßler, Wilhelm E. Wemheuer, Ekkehard Schütz, Bertram Brenig (2017): Bilateral iridal hypopigmentation in Holstein Friesian cattle. Poster and Book of Abstracts. 36th International Society for Animal Genetics (ISAG) Conference, 16. - 21. Juli 2017, Dublin, Irland.

Anne K. Hollmann, Insa Dammann, Wiebke M. Wemheuer, Wilhelm E. Wemheuer, Almuth Chilla, Andrea Tipold, Walter J. Schulz-Schaeffer, Julia Beck, Ekkehard Schütz, Bertram Brenig (2017): Congenital cataract formation in Holstein Friesian cattle is associated with a nonsense mutation in bovine CPAMD8 gene. Poster and Book of Abstracts. 36th International Society for Animal Genetics (ISAG) Conference, 16. - 21. Juli 2017, Dublin, Irland. 


\section{Zusammenfassung}

Die vorliegende Studie befasst sich mit dem Auftreten von Augenerkrankungen bei Holstein Friesian (HF) Rindern. Im ersten Teil der Studie wurden 31 Rinder mit kongenitaler Katarakt untersucht. Diese Tiere zeigten bereits bei der Geburt eine bilaterale vollständige Trübung der Linse (Cataracta matura). Katarakte sind häufig genetisch bedingt und werden durch Mutationen in für Linsenproteine codierenden Genen hervorgerufen. Durch eine Pedigreeanalyse der erkrankten HF Rinder konnte eine nahe Verwandtschaft aller Katarakttiere nachgewiesen und der potentiell zugrunde liegende Erbgang als autosomal rezessiv definiert werden. Mittels einer genomweiten Assoziationsstudie von 26 betroffenen und 88 gesunden Kontrolltieren sowie einer genomweiten Re-Sequenzierung von einem Tier mit kongenitaler Katarakt und vier Nahverwandten konnte eine mit der Erkrankung assoziierte Mutation auf dem bovinen Chromosom $7 \mathrm{im}$ CPAMD8-Gen (C3 and PZP like, alpha-2-macroglobulin domain containing 8) an Position g.5995966C>T (UMD_3.1) ermittelt werden. Die MissenseMutation (p.Gln74*) in Exon 1 des Gens führt zu einem vorzeitigen Stopcodon und damit zum Verlust des korrespondierenden Proteins bei homozygot betroffenen Rindern. Eine Genotypisierung der Variante g.5995966C>T wurde an einer Kohorte von insgesamt 1248 HF Rindern durchgeführt. Alle betroffenen Rinder mit kongenitaler Katarakt wurden als homozygot TT typisiert. Ferner konnten insgesamt 161 Anlageträger in der untersuchten Kohorte identifiziert werden. Darunter befanden sich auch alle getesteten Elterntiere der Kataraktrinder. Eine Expression von CPAMD8 konnte in fetalen, adulten und kataraktogenen Linsen nachgewiesen werden. Auf Proteinbasis konnte CPAMD8 mittels Immunhistochemie bei gesunden Kontrolltieren im unpigmentierten Teil des Ziliarkörperepithels nachgewiesen werden. Die biologische Funktion von CPAMD8 ist bisher ungeklärt. Dennoch kann aus den Ergebnissen der Studie abgeleitet werden, dass ein Verlust des CPAMD8 Proteins, bedingt durch die identifizierte Mutation auf Chromosom 7 an Position g.5995966C>T, zum Auftreten von kongenitalen Katarakten beim HF Rind führt.

Im zweiten Teil der vorliegenden Studie wurden der Phänotyp und die genetische Grundlage der iridalen Hypopigmentierung beim HF Rind untersucht. Insgesamt standen für die Studie 18 HF Rinder mit bilateraler Irishypopigmentierung unterschiedlicher 
Ausprägung zur Verfügung. Makroskopisch konnte bei allen betroffenen Tieren eine aus zwei Farbringen bestehende Iriskoloration nachgewiesen werden. Der zentrale Ring rund um die Pupille zeigte sich silbergrau bis graublau, die Peripherie hingegen hellbraun bis grau. Histologisch konnte eine Reduktion der Irispigmentierung festgestellt werden, welche hauptsächlich die vordere Grenzschicht und das Irisstroma betraf. Die ophthalmologische und neurologische Untersuchung von zwei betroffenen Rindern zeigte keine weiteren Anomalien und ebenfalls keine Anzeichen für eine syndrombedingte Erkrankung. Eine okulokutane Hypopigmentierung, wie bei Simmental und Angus Rindern vorkommend, konnte ferner ausgeschlossen werden. Um die genetische Grundlage der Irishypopigmentierung zu untersuchen, wurde eine genomweite Assoziationsstudie mittels Genotypisierungsdaten von 18 betroffenen und 172 zufällig ausgewählten HF Rindern durchgeführt. Dabei konnten auf Chromosom 8 im Bereich von 57,3-65,3 Mb (UMD3.1.1) insgesamt sieben Marker mit p-Werten über dem genomweiten Signifikanzniveau nach Bonferroni von $-\log _{10}(p)=6,65$ identifiziert werden. Der Marker (BTB-00352779) mit der höchsten Assoziation $\left(-\log _{10}(p)=9,17\right)$ lag dabei an Position 60.990.733. In dem assoziierten Bereich auf Chromosom 8 war jedoch kein Gen lokalisiert, welches bisher direkt mit Pigmentierungsprozessen in Verbindung gebracht werden konnte. Die Genotypisierungsdaten der 18 betroffenen Tiere wurden mit einer weiteren Kohorte zufällig ausgewählter HF Rinder ( $n=316)$ verglichen. Dabei konnte errechnet werden, dass ein A-Allel an Position 60.990.733 (BTB-00352779) zu einer signifikant höheren Wahrscheinlichkeit von iridaler Hypopigmentierung führt. Aus den Ergebnissen dieser Studie lässt sich ein vorrangig kosmetischer Effekt der iridalen Hypopigmentierung ableiten. Die genetische Ausprägung der Pigmentreduktion ist mit einem Bereich auf Chromosom 8 (57,3-65,3 Mb) assoziiert. 


\section{Summary}

The current study deals with ophthalmological anomalies in Holstein Friesian (HF) cattle and is divided into two parts. The first part of the study considers the development of congenital cataracts in HF cattle. In total 31 cases were examined showing bilateral mature cataracts at time of birth. Pedigree analysis revealed a relationship of all cataract cases indicating an autosomal recessive inheritance of the disorder. A case-control association study based on genotyping data of 26 cases and 88 controls and a subsequent whole genome re-sequencing of one case and four closely related cattle revealed a nonsense mutation in CPAMD8 gene (C3 and PZP like, alpha-2-macroglobulin domain containing 8, g.5995966C $>\mathrm{T}$, p.Glu74*). Genotyping of the variant g.5995966C $>\mathrm{T}$ in CPAMD8 was performed on a cohort of 1,248 animals. All cataract cases were identified as homozygous affected. All as heterozygous tested cattle $(n=161)$, including all investigated parents of cataract cases, were related to a common ancestor detected by pedigree analysis. RNA expression of CPAMD 8 was detected in fetal, healthy adult and cataractous lenses and immunohistochemical analysis revealed the presence of CPAMD8 protein in the ciliary body epithelium of healthy cattle. However, the biological function of CPAMD8 remains unknown. Nevertheless, our data provide convincing evidence that the absence of CPAMD8 protein leads to congenital cataract formation in HF cattle.

In the second part of the present study $18 \mathrm{HF}$ cattle with bilateral iridal hypopigmentation were examined. All cases showed an iris coloration with two differently colored parts of varying color intensity. The central regions appeared silveryblue to gray-blue with darker and lighter parts while the peripheries showed a light brown to gray coloration with occasional light gray zones. Histological evaluation revealed a reduction in iris pigmentation mainly affecting the anterior border layer and the iridal stroma. Ophthalmological and neurological examination of two cases could not reveal any signs of an underlying syndrome or anomalies other than the iridal hypopigmentation. Oculocutaneous hypopigmentation as detected in Simmental and Angus breed could also be excluded as potential cause of the hypopigmentation. To analyze the genetics of the iris hypopigmentation, a genome-wide association study was performed using genotyping data of the 18 cases and 172 randomly selected HF cattle. 
In total seven loci with p-values above the Bonferroni genome-wide significance level of $-\log _{10}(p)=6.65$ were detected on bovine chromosome 8 spanning from 57.3 to $65.3 \mathrm{Mb}$ (UMD3.1.1). The loci (BTB-00352779) with the highest $-\log _{10}(p)=9.17$ was located at position $60,990,733$. However, none of the genes located in the associated region on chromosome 8 were previously reported to be directly involved in pigmentation processes. The genotyping data of the 18 affected cattle were compared to another cohort of randomly selected HF cattle $(n=316)$. Analysis of genotypic and allelic dependences showed that the presence of an A-allele at position 60,990,733 (BTB-00352779) significantly increased the chance of iridal hypopigmentation. Taking all findings together the study revealed a predominantly cosmetic character of the identified iridal hypopigmentation. Genetically the hypopigmentation is highly associated with a region on chromosome 8 (57.3-65.3 Mb). 
KAPITEL 1

Allgemeine Einleitung 


\section{Allgemeine Einleitung}

Basierend auf Literaturangaben bewegt sich die Häufigkeit boviner Augenerkrankungen zwischen 5,25 \% (Tamilmahan et al., 2013) und 41,8 \% (Hof, 2015). Die von Hof (2015) untersuchten Tiere $(n=925)$ stammten von vier verschiedenen Betrieben, welche teilweise bereits Probleme mit dem gehäuften Auftreten von Augenerkrankungen zeigten. Dieser Aspekt lässt darauf schließen, dass die hohe Anzahl betroffener Tiere voraussichtlich nicht repräsentativ für den Gesamtbestand deutscher Rinder ist. Dennoch unterstreicht es die Bedeutung weiterer Untersuchungen zu Augenerkrankungen beim Rind. Dies gilt im Besonderen für das Auftreten von Katarakten, welche in der Studie von Hof (2015) bei mehr als $25 \%$ der Rinder diagnostiziert wurden. Eine ätiologische Aufklärung der in Lokalisation und Ausprägung variablen Linsentrübungen erfolgte nicht.

Mittels molekularbiologischer Untersuchungsmethoden können Gendefekte heute in überschaubarem Zeitrahmen aufgeklärt werden. Die Identifikation der kausalen Mutation einer Erkrankung hat den großen Vorteil, dass im Anschluss potentielle Vererber der Erkrankung in der Population durch Genotypisierung ermittelt werden können und so über geeignete Zuchtstrategien eine Eindämmung des Defekts erreicht werden kann.

Die vorliegende Arbeit befasst sich daher mit molekulargenetischen Untersuchungen zu Augenerkrankungen des Rindes wie der kongenitalen Linsentrübung und der Irishypopigmentierung.

\subsection{Anatomie und Embryologie von Linse und Iris}

\subsubsection{Linse}

Die Linse liegt in der hinteren Augenkammer und wird dem für die Lichtbrechung verantwortlichen dioptrischen Apparat des Auges zugeordnet (Grehn, 2012). Nach außen wird die transparente und bikonvexe Linse von der Linsenkapsel begrenzt. Diese bildet den Ansatzpunkt der Zonulafasern (Fibrae zonulares), welche von der Linse bis zur 
Pars plicata verlaufen. Dieser Teil des Ziliarkörpers enthält die Aufhängung der Zonulafasern, die Ziliarfortsätze (Processus ciliaris) sowie den für die Akkommodation der Linse zuständigen Ziliarmuskel (Stevens und Lowe, 1992; Grehn, 2012). Bei der Fokussierung der Linse kommt es durch die Akkommodation zu einem stets scharfen Abbild auf der Netzhaut, unabhängig von der Entfernung des betrachteten Gegenstands (Grehn, 2012). Die Linsenkapsel liegt am anterioren Linsenpol direkt dem Linsenepithel auf. Zeitlebens werden aus den mitotisch aktiven Zellen des Linsenepithels neue Linsenfasern gebildet, die sich auf Höhe des Linsenäquators elongieren und in konzentrischen Bahnen um den im Inneren liegenden Linsenkern legen (Graw, 2003, 2010). Im Zuge der terminalen Faserzelldifferenzierung kommt es schließlich zum Abbau der Zellorganellen der Linsenfaserzellen, wodurch die Transparenz der Linse erreicht wird (Bassnett und Mataic, 1997; Bassnett, 2009).

Embryonal entwickelt sich die Linse aus einer Verdickung des Oberflächenektoderms, der Linsenplakode (Graw, 2010). Diese Entwicklung findet beim Rind bei einer Fetusgröße von $6 \mathrm{~mm}$ statt (Gelatt, 2014). Im Anschluss an die Ausprägung der Linsenplakode stülpt sich der Linsenbecher ein. Die Zellen des Linsenbechers schließen sich zu einer epithelialen Hohlkugel, dem Linsenbläschen. Daraufhin kommt es zur Loslösung des Linsenbläschens vom Oberflächenektoderm. Die Linsenzellen am posterioren Pol des Linsenbläschens elongieren im nächsten Schritt und füllen letztendlich den vollständigen Hohlraum des Linsenbläschens aus. Diese Zellen werden auch als primäre Linsenfaserzellen oder als Linsenkern bezeichnet (Graw, 2003, 2010). Die Entwicklung der primären Linsenfaserzellen findet beim Rind bei einer Fetusgröße von $15 \mathrm{~mm}$ statt (Gelatt, 2014). Vom anterioren Pol der Linse entstehen nun aus den Epithelzellen die sekundären Linsenfaserzellen. Sie bilden die Linsenrinde (Cortex). Die Y-förmigen Linsennähte entstehen dabei als Verbindungen der elongierten sekundären Linsenfasern an den sich gegenüberliegenden Linsenäquatoren (Graw, 2003, 2010).

Die adulte Linse besteht zu 65-70\% aus Wasser und zu 30-35\% aus dichtgepackten Proteinen, von denen die $\left(\alpha_{-}^{-}, \beta_{-}^{-}, \gamma^{-}\right)$Kristalline den Hauptanteil ausmachen (Graw, 2009a). Neben den Kristallinen sind weitere Strukturproteine wie Transmembran- und Zytoskelettproteine, Connexine, Kollagene und Intermediärfilamente in der Linse vorhanden (Graw, 2010). Da im Zuge der terminalen Faserzelldifferenzierung alle Zellorganellen der Linsenfaserzellen abgebaut werden, erfolgen die Bereitstellung der 
nötigen Nährstoffe und der Abtransport von schädlichen Stoffwechselendprodukten über das im unpigmentierten Teil des Ziliarepithels produzierte Kammerwasser (Reddy, 1979). Durch aktiven Transport gelangen die Ionen und Metaboliten in die Linse (Harris und Becker, 1965; Gelatt, 2014). Der Weitertransport der Nährstoffe innerhalb der Linse erfolgt über die sogenannten Gap junctions (Berthoud und Beyer, 2009).

\subsubsection{Iris}

Die Iris bildet die Fortsetzung des Ziliarkörpers (Corpus ciliare) und liegt zwischen der vorderen und hinteren Augenkammer. Sie besteht aus drei verschiedenen Schichten (vordere Grenzschicht, Irisstroma und Irispigmentepithel) und beinhaltet zwei funktionell konträr agierende Muskeln (Musculus sphincter pupillae und Musculus dilatator pupillae). Die vordere basalmembranlose Grenzschicht ist vor allem aus Fibroblasten und Melanozyten aufgebaut. Das sich anschließende Irisstroma besteht aus einem lockeren Geflecht an Kollagenfasern, Fibroblasten, Melanozyten, Nervenfasern und Blutgefäßen (Gelatt, 1991; Stevens und Lowe, 1992; Gelatt, 2014). Das Irispigmentepithel wird durch zwei Schichten von dicht verbundenen pigmentierten Zellen gebildet. Die zwei glatten iridalen Muskeln, Musculus sphincter pupillae und Musculus dilatator pupillae, sind für Miosis (Musculus sphincter pupillae) und Mydriasis (Musculus dilatator pupillae) der Pupille und somit für die Regulation des Lichteinfalls ins Auge verantwortlich. Der Musculus sphincter pupillae liegt dabei im Irisstroma nahe dem Pupillenrand, der Musculus dilatator pupillae hingegen erstreckt sich entlang des Irispigmentepithels bis zum Musculus sphincter pupillae. Die Regulation der Kontraktion der beiden Muskeln erfolgt über den Parasympathikus (Musculus sphincter pupillae) und den Sympathikus (Musculus dilatator pupillae) (Gelatt, 1991; Stevens und Lowe, 1992; Gelatt, 2014). Die embryonale Einstülpung des Augenbechers wird als wichtiger Schritt der Iris- sowie Ziliarkörperentwicklung gesehen (Graw, 2010). Die vordere Grenzschicht sowie das Irisstroma entwickeln sich embryonal aus Zellen der Neuralleiste. Das Irispigmentepithel wie auch die iridalen Muskeln sind hingegen neuroektodermalen Ursprungs (Cvekl und Tamm, 2004; Gelatt, 2014). 


\subsection{Katarakt}

\subsubsection{Kataraktdefinition und Einteilung}

Katarakte sind Linsentrübungen, die das Sehvermögen der Betroffenen mindern. Die Trübungen können sowohl unilateral, als auch bilateral auftreten. Je nach Lokalisation und Entwicklungsstadium der Trübung kann es auch zu völliger Blindheit der Patienten kommen. Katarakte können sämtliche Strukturen der Linse, wie die Linsenkapsel (Cataracta capsularis, subcapsularis), die -rinde (Cataracta corticalis), den -kern (Cataracta nuclearis), den -pol (Cataracta polaris), den -äquator und die Y-Nähte der Linse betreffen (Grehn, 2012). Die Entwicklungsstadien der Trübungen lassen sich von „klar", über „unreif“ (Cataracta immatura), „reif“ (Cataracta matura), „überreif“ (Cataracta hypermatura) einteilen (Sparrow et al., 1986).

Bei einer Cataracta hypermatura kann es zur Ausbildung der sogenannten MorgagniKugeln kommen. Morgagni-Kugeln sind eosinophile Kugeln, die aus zerbrochenen Linsenfaserzellen der Rinde entstehen und sich letztlich zu einer homogenen milchigen Flüssigkeit entwickeln (Cogan, 1962). Kommt es zu einer vollständigen Verflüssigung der Linsenrinde mit optionalem Absacken bzw. Verlust des Linsenepithels, wird die Trübung als überreif bezeichnet. Bei einer Cataracta hypermatura kann es zudem zu einem Auslaufen der Linsensubstanz durch die Kapsel in die vordere Augenkammer kommen. Die vollständige Verflüssigung der Linsenrinde und das Absinken des Linsenkerns werden als Morgagni-Katarakt (Cataracta morgagni) bezeichnet (Caccamise, 1955; Cogan, 1962). Neben den genannten Veränderungen kann es ebenfalls zu einem Anschwellen der Linse (Cataracta intumescens) kommen. Ebenso können eine Linsenluxation, eine Dislokation, eine Veränderung der Linsenform (Lentikonus) oder das vollständige Fehlen der Linse (Aphakie) auftreten (Sparrow et al., 1986).

Neben der Einteilung nach Lokalisation und Entwicklungsstadium wird, je nach Zeitpunkt der Kataraktentstehung, zwischen kongenitalen, infantilen, juvenilen, präsenilen und senilen Linsentrübungen unterschieden (Yi et al., 2011). 


\subsection{2 Ätiologie der Katarakt}

Kataraktogene Noxen sind vielfältig. Zur ätiologischen Einteilung muss zunächst zwischen erworbenen und angeborenen Linsentrübungen differenziert werden. Erworbene Katarakte können beim Menschen durch verschiedene Risikofaktoren wie u.a. Rauchen, Alkoholkonsum und Diabetes begünstigt werden (Hodge et al., 1995; West und Valmadrid, 1995; Na et al., 2014). Des Weiteren können Linsentrübungen u.a. durch Verletzungen, Vergiftungen, nach intraokularen Operationen und durch Strahlung (UV) entstehen (Schmidt, 1973; Shichi, 2004; Grehn, 2012). Eine häufige Form humaner Linsentrübungen ist die Cataracta senilis (Altersstar), die in der Regel als Linsentrübung ab einem Alter von 45 Jahren definiert ist (Shiels und Hejtmancik, 2007). Im Verlauf des Lebens kommt es innerhalb der Linse zu posttranslationalen Veränderungen der Linsenkristalline sowie Konformationsänderungen und zum Verlust der Chaperonaktivität der Linsenproteine. Zudem wird die Wirkung von Antioxidantien und die Bindungskapazität freier Radikale eingebüßt (zusammengefasst in Michael und Bron, 2011). Konformationsänderungen können u.a. durch Glykation, Deamidierung, Carbamylierung, die Ausbildung von Disulfidbrücken oder C- und N-terminale Degenerationen ausgelöst werden (Harding, 2002). Durch eine Akkumulation von fehlgefalteten Proteinen und der anschließenden Aggregation dieser, werden die Trübungen letztendlich direkt bewirkt (Harding, 2002). Sind die Linsentrübungen bereits bei der Geburt vorhanden, werden diese als konnatale oder kongenitale Katarakte bezeichnet. Konnatale Katarakte werden durch intrauterine Infektionen wie z.B. beim Rind die Bovine Virus-Diarrhoe/Mucosal Disease (BVD/MD) ausgelöst (Bistner et al., 1970). Kongenitale Katarakte entstehen durch Störungen während der embryonalen Linsenentwicklung ausgelöst durch Mutationen in für Linsenproteine codierenden Genen. Für Mensch und Maus sind bereits über 290 Gene und an die 20 Loci beschrieben, die mit dem Auftreten von Katarakt assoziiert wurden (Shiels et al., 2010, 2016). In Bezug auf ihre Funktion lassen sich die betroffenen Gene in mehrere Gruppen einteilen. Die wohl bedeutendste Gruppe aller Linsenproteine bilden mit einem Anteil von über $90 \%$ die Kristalline (Horwitz, 2003). $\alpha$-Kristalline sind kleine Hitzeschockproteine, die eine Chaperonaktivität aufweisen, wodurch die Aggregation von Proteinen verhindert wird (Horwitz, 1992, 2003). $\beta$ - und $\gamma$-Kristalline werden in der Regel zu einer 
Superproteinfamilie zusammengefasst und codieren für Strukturproteine (Graw, 2009b). In der Linse sind die $\boldsymbol{\gamma}$-Kristalline vorwiegend im Linsenkern zu finden (Slingsby et al., 2013). Mutationen in allen drei Kristallingruppen konnten bereits mit der Entstehung kongenitaler Katarakte assoziiert werden (zusammengefasst in Graw, 2004). Neben den Kristallinen sind ebenfalls Mutationen in Genen bekannt, welche für Transkriptionsfaktoren, Membrantransportproteine, Zytoskelettproteine oder metabolisch wirksame Proteine codieren (Hejtmancik, 2008; Michael und Bron, 2011; Shiels und Hejtmancik, 2015). So führen Mutationen in Transkriptionsfaktoren wie z.B. PAX6, PITX3, FOXE3, SOX2 und MAF zur embryonalen Entwicklung kongenitaler Katarakte. Funktionell übernehmen diese Gene essentielle Aufgaben während der Augen- und Linsenentwicklung (Graw, 2004, 2009b). Aus der Klasse der Membranproteine sind u.a. die Gene GJA3 und GJA8 als Kandidatengene für kongenitale Kataraktentwicklung bekannt (Shiels et al., 1998; Mackay et al., 1999; Graw, 2004; Hejtmancik, 2008). Sie codieren für die Connexine 46 und 50, welche Hauptbestandteil der sogenannten Gap junctions sind und den Nährstofftransport ins Innere der sonst avaskulären Linse ermöglichen (Berthoud und Beyer, 2009). Mutationen in den Genen GJA3 und GJA8 sind in der Regel mit nukleären und zonular pulverförmigen Trübungen assoziiert (Shiels und Hejtmancik, 2013). Im Allgemeinen können jedoch Mutationen in verschiedenen Genen zu identischen Kataraktausprägungen führen. Ebenfalls ist es möglich, dass Mutationen innerhalb eines Kandidatengens zu unterschiedlicher Ausprägung der Linsentrübungen führen (Graw, 2004; Hejtmancik, 2008).

Neben den genannten Linsenproteinen sind viele weitere Linsenproteine und ebenfalls Proteine mit bisher ungeklärter Funktion von kataraktogenen Mutationen betroffen. Eine zumeist aktuelle Liste der mit Katarakt assoziierten Gene bei Mensch und Maus kann bei Shiels et al. (2016) online (http://cat-map.wustl.edu) abgerufen werden (siehe dazu auch Shiels et al., 2010).

Katarakte treten in einigen Fällen in Kombination mit weiteren ophthalmologischen Anomalien des vorderen Augensegments wie z.B. Mikrophthalmie und Aniridie auf. Ebenfalls ist ein Auftreten von Linsentrübungen beim Menschen im Rahmen von Syndromen wie Lowe und Nance-Horan möglich (Shiels und Hejtmancik, 2013). Der Erbgang kongenitaler Katarakte kann sowohl autosomal dominant, autosomal rezessiv oder X-chromosomal sein (Hejtmancik, 2008). 


\subsubsection{Auftreten von Katarakt beim Rind}

Bereits 1919 beschrieb Small das Auftreten von Katarakten beim Rind (Small, 1919). Bei den untersuchten Rindern konnten die Linsentrübungen genetisch auf einen viel eingesetzten HF-Bullen zurückgeführt werden. Der Erbgang wurde dabei als rezessiv angegeben (Detlefson und Yapp, 1920). Insgesamt konnten bis heute Katarakte bei einer Vielzahl von Rinderrassen wie Holstein Friesian (Detlefson und Yapp, 1920; Carter, 1960; Ashton et al., 1977; Hurley, 2008), Jersey (Gregory et al., 1943; Saunders und Fincher, 1951), Hereford (Gelatt, 1971), Aberdeen Angus (Gelatt, 1971), Shorthorn (Gelatt, 1971), Ayrshire (Krump et al., 2014) und Romagnola (Murgiano et al., 2014) beobachtet werden. Die meist bilateralen Linsentrübungen waren dabei sowohl in ihrer Lokalisation, als auch bezogen auf das Entwicklungsstadium sehr unterschiedlich. Es konnten Trübungen des Linsenkerns (Ashton et al., 1977; France und Shaw, 1990; Krump et al., 2014; Murgiano et al., 2014), der Linsenrinde (Gelatt, 1971), der Linsenkapsel (Gelatt, 1971) sowie vollständig getrübte Linsen (Carter, 1960; Gelatt, 1971) beobachtet werden. Bezogen auf das Entwicklungsstadium der Linsentrübungen konnten Katarakte der Kategorien „unreif“ (Murgiano et al., 2014), „reif“ (Small, 1919; Gelatt, 1971) und „überreif“ (hypermatur) (Gelatt, 1971) näher beschrieben werden. Auch wurde bei einem Tier unbekannter Rasse die Ausbildung von Morgagni-Kugeln beobachtet (Ushigusa et al., 2000). Ebenso konnte Carter (1960) eine Veränderung der Linsentrübung nach Ruptur der posterioren Linsenkapsel feststellen. Durch den Riss kam es zu einer Linsendislokation mit anschließendem Zerfall der Linse. Neben den Linsentrübungen wurden in einigen Fällen die Ausprägungen weiterer ophthalmologischer Anomalien wie u.a. Hornhauttrübung, Netzhautablösung (Carter, 1960; Gelatt, 1971), Makrophthalmos, Mydriasis (Carter, 1960), Mikrophakie (Saunders und Fincher, 1951), Linsendislokation (Saunders und Fincher, 1951; Carter, 1960), Synechie, Iridozyklie, Mikrophthalmie und Hypoplasie des Sehnervs (Gelatt, 1971) berichtet. Außerdem konnten vier Fälle von Katarakt und Hydrocephalus beschrieben werden (Ushigusa et al., 2000). Das Auftreten des von Carter (1960) beschriebenen Defekts war zudem semiletal.

In vielen Fällen wurde eine genetische Ursache der Genese der Katarakte vermutet. Die Vererbung wurde dabei sowohl als autosomal rezessiv (Detlefson und Yapp, 1920; 
Saunders und Fincher, 1951; Murgiano et al., 2014) als auch als autosomal dominant (Carter, 1960) angegeben. Allerdings konnte bisher nur in einer Studie die zugrunde liegende Mutation der Kataraktentwicklung beim Rind identifiziert werden (Murgiano et al., 2014). Bei Romagnola Rindern mit bilateraler unvollständiger unreifer nukleärer Katarakt wurde die ursächliche Mutation der Trübungen im NID1-Gen (nidogen 1) lokalisiert. Insgesamt konnten eine Missense-Variante (c.687G $>$ C) und eine Deletion (c.3579_3604+829del) nachgewiesen werden, die beide in homozygot betroffenem Status nur bei den von Katarakt erkrankten Rindern vorlagen, wobei die Deletion von den Autoren als Ursache der Kataraktentwicklung vermutet wurde (Murgiano et al., 2014).

In einigen Herden konnte eine verhältnismäßig hohe Inzidenz der Linsentrübungen festgestellt werden. Ashton et al. (1977) berichteten von zwei Friesian-Rinderherden, bei denen 30 bzw. 34 \% der neugeborenen Kälber betroffen waren. Hof (2015) führte ophthalmologische Untersuchungen an 925 Rindern unterschiedlicher Rasse und unterschiedlichen Alters durch. Dabei konnten bei über einem Viertel der Tiere Linsentrübungen beobachtet werden, welche in Lokalisation und Ausprägung deutlich variierten. Die Katarakte traten bei 63,8 \% der betroffenen Rinder als alleinige okulare Veränderung auf. Eine Untersuchung der Ätiologie der Linsentrübungen fand indes nicht statt (Hof, 2015). Krump et al. (2014) beschrieben kongenitale Katarakte in einer Herde Ayrshire Rinder, wobei 26 \% der Tiere von Linsentrübungen betroffen waren. Eine Pedigreeanalyse der betroffenen Ayrshire Rinder stellte keine nähere Verwandtschaft der Mütter heraus. Neben genetischen Effekten sind auch Veröffentlichungen zum Auftreten von Katarakt im Zusammenhang mit intrauterinen Infektionen wie BVD/MD bekannt. Infiziert sich das Muttertier während der Trächtigkeit mit dem BVD/MDErreger wird die Entwicklung des Fetus gestört und es kommt zur Ausprägung schwerwiegender Anomalien wie Hypoplasie des Kleinhirns und Fehlentwicklungen der Augen mit Katarakt (Bistner et al., 1970). Die diagnostizierten Linsentrübungen durch BVD/MD betreffen vor allem die Linsenrinde (Cataracta corticalis). Die in der Studie von Krump et al. (2014) untersuchten Rinder mit Kernkatarakt bzw. einer perinukleären Trübung wiesen allerdings keine Anzeichen für eine BVD/MD Infektion auf. Neben BVD/MD wurde in einer weiteren Studie eine Infektion mit dem Schimmelpilz Rhizopus 
als ursächlich für die Entwicklung von Katarakt angesehen (Vasconcelos und Grahn, 1995).

Der Vollständigkeit halber ist zu erwähnen, dass 2012 das Auftreten von nukleären Katarakten beim Braunvieh mit der Errichtung eines Mobilfunkmastes in Verbindung gebracht wurde. Die zugrunde liegende Ursache der Kataraktgenese wurde allerdings nicht identifiziert (Hässig et al., 2012).

\subsection{Irishypopigmentierung und Heterochromia iridis}

Als Irishypopigmentierung wird eine Minderpigmentierung der Iris bezeichnet, die sich in einer Aufhellung der Irisfarbe manifestiert. Die Irisheterochromie (Heterochromia iridis) im Speziellen bezieht sich auf Farbunterschiede innerhalb einer Iris oder zwischen den Iriden eines Individuums (Gelatt, 2014).

\subsubsection{Grundlagen der Pigmentierung}

Die Pigmentierung der Iris erfolgt durch das in den Melanozyten synthetisierte Melanin. Melanin lässt sich in zwei verschiedene Arten aufteilen, das braun-schwarze Eumelanin und das gelb-rote Phäomelanin (Colombo et al., 2011). Neben der Iris lassen sich Melanozyten in zahlreichen Körpergeweben finden (Haut, Haare, Ohr, Gehirn, Fettzellen) und sind ebenfalls in weiteren okularen Strukturen wie dem retinalen Pigmentepithel (RPE), der Choroidea und dem Ziliarkörper vorhanden (Colombo et al., 2011). Embryonal entstammen die Melanozyten der verschiedenen Gewebe der Neuralleiste (Colombo et al., 2011). Alleinig die Melanozyten des RPE stammen aus dem Neuroektoderm (Bharti et al., 2006; Colombo et al., 2011).

Melanozyten weisen spezielle Lysosom-ähnliche Zellen auf, die Melanosomen, die in mehreren komplexen Schritten heranreifen und im Endstadium (Schritt 4) dicht gelagertes Melanin enthalten. Während der Reifung der Melanosomen kommt es zunächst zur Bildung von Prämelanosomen, welche eine vesikuläre Struktur mit einigen wenigen unregelmäßig angeordneten Fibrillen aufweisen (Schritt 1). Im nächsten Schritt (Schritt 2) erfolgt die Ausbildung einer vollständigen, konzentrisch geformten fibrillären 
Matrix. Erst in Phase 3 beginnt die Synthese und Einlagerung von Melaninpigment entlang der gebildeten Matrix (Schritt 3) (Seiji et al., 1963; Marks und Seabra, 2001; Raposo et al., 2001). Voll entwickelte Melanosomen der okularen Melanozyten verbleiben, anders als die der Haut, in den Melanozyten und werden nicht an umliegende Keratinozyten transferiert (Sitaram und Marks, 2012). Genetisch wird die Melanogenese maßgeblich von Struktur- und Transportproteinen, Transkriptionsfaktoren sowie weiteren an der Melaninsynthese beteiligten Enzymen beeinflusst (Yamaguchi und Hearing, 2009, 2014).

\subsubsection{Irishypopigmentierung und Heterochromia iridis bei Mensch und Säugetieren}

Veränderungen der Irispigmentierung sind bei zahlreichen Säugetierarten wie Rindern (siehe Kapitel 1.3.3), Wasserbüffeln (Misk et al., 1998), Schweinen (Gelatt et al., 1973; Ollivier und Sellier, 1982), Alpakas (Gauly et al., 2005; Jackling et al., 2014), Lamas (Gauly et al., 2005), Pferden (Magdesian et al., 2009; Bergstrom et al., 2014), Schafen (Rowett und Fleet, 1993; Lang, 1995, 1999; Lühken et al., 2012), Hunden (Shively und Phemister, 1968; Stritzel et al., 2009), Katzen (Thibos et al., 1980) und Goldhamstern (Magalhaes et al., 1962) bekannt. Eine Veränderung der Augenfarbe konnte ebenfalls bei Mäusen beobachtet werden (Brooks et al., 2007; Vogel et al., 2008; Trantow et al., 2009).

Anders als bei den oben genannten Säugetierarten ist die natürlich auftretende Ausprägung der Irisfarbe beim Menschen deutlich variabler. Die zugrunde liegende Genetik ist noch nicht vollständig aufgeklärt, es wird jedoch von einer polygenen Vererbung ausgegangen (Rennie, 2012). Ausgehend vom kombinierten Auftreten von sechs jeweils singulären SNPs (Single Nucleotide Polymorphism) in den Genen HERC2, OCA2, SLC24A4, SLC45A2, TYR, IRF4 lässt sich die Farbausprägung für braune, blaue und intermediäre Augenfarben mit einem AUC (area under the curve) von 0,93 bzw. 0,91, und 0,73 vorhersagen (Liu et al., 2009). Okulokutane Hypopigmentierungen treten beim Menschen oftmals im Zusammenhang mit monogenen Syndromen wie dem Okulokutanen Albinismus (Gronskov et al., 2007), Waardenburg-Syndrom (Eigelshoven et al., 2009; Shields et al., 2013), Hermansky-Pudlak- (Gahl et al., 1998) und ChediakHigashi-Syndrom (Introne et al., 1999; Ho und Hsieh, 2013) auf. Heterochromia iridis 
wurde beim Menschen u.a. in Zusammenhang mit dem Horner-Syndrom (Diesenhouse et al., 1992; Renard et al., 2010) und der Fuchs Heterochromen Iridozyklitis (Schwab, 1990) berichtet.

\subsubsection{Phänotypische Ausprägung von Irisheterochromie und Irishypo- pigmentierung beim Rind}

In den späten 1960ern befasste sich beim Rind vor allem die Arbeitsgruppe um Horst W. Leipold und Keith Huston mit dem Auftreten iridaler Farbveränderungen. Die beobachteten Pigmentierungsveränderungen wurden dabei zumeist als Irisheterochromie (Heterochromia iridis) oder aber als Glasauge bezeichnet.

Tabelle 1 fasst die detektierten bovinen iridalen Pigmentierungsalterationen und die jeweilige phänotypische Ausprägung, soweit näher beschrieben, zusammen. Es wird dabei deutlich, dass ein Großteil der Farbveränderungen im Zusammenhang mit Syndromen wie Albinismus, Tietz- oder auch Chediak-Higashi auftreten. So beschrieben Leipold und Huston (1966) bei von Albinismus betroffenen Hereford Rindern eine bilaterale Verfärbung der Iris mit hellblauem Zentrum und weißer Peripherie. Hauptgrund der iridalen Farbänderung war der Verlust der Pigmentierung der vorderen Grenzschicht und des Irisstromas sowie die Minderpigmentierung des posterioren Pigmentepithels (Leipold und Huston, 1966). Diese Ausprägung der Irisheterochromie wurde auch bei einem weiteren Fall von vollständigem Albinismus bei einem Guernsey Kalb beobachtet (Leipold et al., 1968).

Bei Tieren mit unvollständigem Albinismus konnte ein hellblaues Iriszentrum und eine graue Peripherie beobachtet werden. Dabei war die Irisfarbe zum Teil jedoch nicht einheitlich erhellt, sondern eher gescheckt (Leipold und Huston, 1968a). Histologisch zeigte sich das hellblaue Iriszentrum unpigmentiert (Stroma und anteriore Grenzschicht), die graue Peripherie wies eine Minderpigmentierung der vorderen Grenzschicht und des Irisstromas auf. Das posteriore Pigmentepithel war hingegen hyperpigmentiert. In Bereichen, in denen die graue Färbung nicht einheitlich war, konnte im posterioren Stroma keine Pigmentierung detektiert werden. Im anterioren Irisstroma zeigten sich jedoch größere Pigmentklumpen. Das posteriore Pigmentepithel war dabei mäßig pigmentiert (Leipold und Huston, 1969). 
Bei einem weiteren Hereford Rind mit Heterochromia iridis und rassespezifischer Fellfärbung konnte der Grund der iridalen Farbveränderung (blaues Zentrum und braune Peripherie) auf eine Hypoplasie des Irisstromas und eine verminderte Pigmentierung in allen drei Irisschichten zurückgeführt werden. Darüber hinaus fanden sich im Irisstroma Konzentrationen von Pigmentklumpen und Regionen ohne Pigmentzellen (Leipold und Huston, 1969). Hof (2015) konnte bei sieben Rindern eine Heterochromia iridis partialis diagnostizieren. Die Farbveränderungen traten unilateral (zwei Tiere), bilateral (fünf Tiere) und teilweise zusammen mit weiteren Augenerkrankungen wie z.B. Katarakt auf. In der Studie wurden ebenfalls verschiedene physiologisch auftretende Farbausprägungen (hellbraun, mittelbraun und dunkelbraun) der Iris bezogen auf unterschiedliche Altersgruppen dokumentiert (Kälber, Jungrinder und Kühe). Dabei konnte ein Zusammenhang zwischen dem Alter und den unterschiedlichen Farbabstufungen der Iris festgestellt werden. Junge Tiere wiesen im Schnitt eine hellere Irisfarbe auf als ältere Rinder (Hof, 2015).

Neben den bereits beschriebenen Fällen konnten Leipold und Huston ebenfalls Farbveränderungen der Iris bei Rindern nachweisen, die nicht von Albinismus betroffen waren. Die meisten dieser Tiere zeigten jedoch weitere Anomalien wie Minderwachstum, Schwanzlosigkeit und Blindheit (Huston et al., 1968).

Reduzierungen der Irispigmentierung konnten ebenfalls im Rahmen vom Tietz- (Philipp et al., 2011) und Chediak-Higashi-Syndrom (Burns et al., 1984) festgestellt werden. Ein Phänotyp, ähnlich dem Tietz-Syndrom bei Menschen, wurde bei deutschen Fleckvieh Rindern beobachtet. Betroffene Tiere zeigten eine weißliche Fellfarbe und ein hellblaues Iriszentrum sowie eine weiße Peripherie. Der Augenhintergrund (Fundus oculi) war ebenfalls unpigmentiert. Als ursächlich für die Ausprägung des Tietz-Syndroms bei Fleckvieh Rindern wird eine Missense-Mutation in Exon 7 (p.Arg210lle) des MITF-Gens angesehen. Die Vererbung des Defekts erfolgt autosomal dominant (Philipp et al., 2011). Das Chediak-Higashi-Syndrom ist beim Rind gekennzeichnet durch eine deutlich erhellte Fellfarbe, erhöhte Blutungsneigung, erhöhte Anfälligkeit für Infektionen und okulokutane Hypopigmentierung. Durch die Minderpigmentierung kommt es zu einer gräulichen Färbung der Iris bei betroffenen Tieren (Padgett et al., 1964; Ayers et al., 1988; Shiraishi et al., 2002). Das Syndrom wurde bereits bei Rindern der Rassen Hereford (Burns et al., 1984), Brangus (Ayers et al., 1988), Wagyu (Japanese Black) (Ogawa et al., 
1997; Kunieda et al., 2000; Yamakuchi et al., 2000) und einer Kreuzung aus Hereford und Angus (Padgett et al., 1967) diagnostiziert. Die ursächliche Mutation des ChediakHigashi-Syndroms bei Wagyu Rindern wurde im LYST-Gen an Position c.6044A>G lokalisiert und führt zu einem Aminosäureaustausch (p.His2015Arg) im entsprechenden Protein. Der Erbgang des Defekts ist autosomal rezessiv (Yamakuchi et al., 2000).

2011 wurde bei Simmental und Angus Rindern eine hauptsächlich kosmetische Veränderung von Iris- und Fellfarbe beobachtet. Bei der okulokutanen Hypopigmentierung zeigen die betroffenen Tiere eine hellblaue Iriskoloration mit hellbrauner Umrandung und eine schokoladenbraune Fellfarbe. Der zugrunde liegende autosomal rezessive Gendefekt konnte im RAB38-Gen lokalisiert werden (persönliche Mitteilung von Jon Beever). Das Gen war bereits aus Studien an Mäusen bekannt. Die betroffenen Mäuse mit einer Mutation in Exon 1 (p.Gly146Thr) zeigten einen ähnlichen Phänotyp mit hellbrauner Fellfarbe und okulärer Hypopigmentierung (Loftus et al., 2002; Brooks et al., 2007). 
Tabelle 1: Zusammenfassung der beobachteten Irispigmentierungsveränderungen bei verschiedenen Rinderrassen

\begin{tabular}{|c|c|c|c|c|c|c|}
\hline Rasse & \multicolumn{2}{|c|}{$\begin{array}{c}\text { Ausprägung der } \\
\text { Pigmentierungsveränderung }\end{array}$} & $\begin{array}{l}\text { Weitere } \\
\text { ophthalmo- } \\
\text { logischen } \\
\text { Verände- } \\
\text { rungen }\end{array}$ & $\begin{array}{l}\text { weitere } \\
\text { Befunde und } \\
\text { detektierte } \\
\text { Syndrome }\end{array}$ & Genort & Referenz \\
\hline Angus & hellblau & hellbraun & $\begin{array}{l}\text { Aufhellung der } \\
\text { Fellfarbe }\end{array}$ & $\begin{array}{l}\text { Okulokutane } \\
\text { Hypopig- } \\
\text { mentierung } \\
\text { (OH) }\end{array}$ & $R A B 38$ & $\begin{array}{l}\text { persönliche } \\
\text { Mitteilung } \\
\text { von Jon } \\
\text { Beever }\end{array}$ \\
\hline Ayrshire & \multicolumn{2}{|c|}{ Iris heller als normal } & & $\begin{array}{c}\text { Minder- } \\
\text { wachstum }\end{array}$ & & $\begin{array}{l}\text { Huston et } \\
\text { al. (1968) }\end{array}$ \\
\hline Brangus & \multicolumn{2}{|c|}{ grau } & & $\begin{array}{l}\text { Chediak- } \\
\text { Higashi- } \\
\text { Syndrom }\end{array}$ & & $\begin{array}{l}\text { Ayers et al. } \\
(1988)\end{array}$ \\
\hline $\begin{array}{l}\text { Deutsches } \\
\text { Schwarz- } \\
\text { buntes } \\
\text { Rind }\end{array}$ & \multicolumn{2}{|c|}{$\begin{array}{l}\text { partielle Graufärbung der Iris } \\
\text { (uni- und bilateral) }\end{array}$} & $\begin{array}{l}\text { Katarakt, Reste } \\
\text { hinterer } \\
\text { Synechien, } \\
\text { Blindheit } \\
\end{array}$ & & & Hof (2015) \\
\hline Fleckvieh & hellblau & weiß & $\begin{array}{l}\text { unpigmen- } \\
\text { tierter Fundus, } \\
\text { Kolobome }\end{array}$ & $\begin{array}{c}\text { Tietz- } \\
\text { Syndrom mit } \\
\text { bilateraler } \\
\text { Taubheit }\end{array}$ & MITF & $\begin{array}{l}\text { Philipp et } \\
\text { al. (2011) }\end{array}$ \\
\hline Hereford & schwach blau & $\begin{array}{c}\text { grau mit } \\
\text { hellen } \\
\text { (weißlichen) } \\
\text { und } \\
\text { dunklen } \\
\text { Bereichen } \\
\end{array}$ & & Albinismus & & $\begin{array}{l}\text { Leipold und } \\
\text { Huston } \\
(1968 b)\end{array}$ \\
\hline Hereford & schwach blau & $\begin{array}{c}\text { grau mit } \\
\text { hellen } \\
\text { (weißlichen) } \\
\text { und } \\
\text { dunklen } \\
\text { Bereichen }\end{array}$ & $\begin{array}{l}\text { Hypoplasie des } \\
\text { Irisstromas, } \\
\text { Tapetum } \\
\text { fibrosum } \\
\text { hypoplastisch, } \\
\text { unpigmentier- } \\
\text { ter Fundus * } \\
\end{array}$ & $\begin{array}{l}\text { Albinismus, } \\
\text { Photophobie }\end{array}$ & & $\begin{array}{c}\text { Leipold und } \\
\text { Huston } \\
\text { (1968a, } \\
1969)\end{array}$ \\
\hline Hereford & $\begin{array}{l}\text { blau mit } \\
\text { weißlichen } \\
\text { Bereichen }\end{array}$ & braun & $\begin{array}{c}\text { reduzierte } \\
\text { Pigmentierung } \\
\text { der weiteren } \\
\text { pigmentierten } \\
\text { Augen- } \\
\text { strukturen, } \\
\text { Hypoplasie des } \\
\text { Irisstromas * }\end{array}$ & & & $\begin{array}{c}\text { Leipold und } \\
\text { Huston } \\
\text { (1968a, } \\
1969)\end{array}$ \\
\hline
\end{tabular}


Fortsetzung Tabelle 1

\begin{tabular}{|c|c|c|c|c|c|c|}
\hline Rasse & \multicolumn{2}{|c|}{$\begin{array}{c}\text { Ausprägung der } \\
\text { Pigmentierungsveränderung }\end{array}$} & $\begin{array}{c}\text { Weitere } \\
\text { ophthalmo- } \\
\text { logischen } \\
\text { Verände- } \\
\text { rungen }\end{array}$ & $\begin{array}{c}\text { weitere } \\
\text { Befunde und } \\
\text { detektierte } \\
\text { Syndrome }\end{array}$ & Genort & Referenz \\
\hline Hereford & \multicolumn{2}{|c|}{ nicht genauer definiert } & & $\begin{array}{l}\text { Chediak- } \\
\text { Higashi- } \\
\text { Syndrom }\end{array}$ & & $\begin{array}{c}\text { Burns et al. } \\
\quad(1984)\end{array}$ \\
\hline Hereford & \multicolumn{2}{|c|}{ grau } & & $\begin{array}{l}\text { Chediak- } \\
\text { Higashi- } \\
\text { Syndrom }\end{array}$ & & $\begin{array}{l}\text { Padgett et } \\
\text { al. (1964) }\end{array}$ \\
\hline $\begin{array}{c}\text { Hereford } \\
x \\
\text { Holstein }\end{array}$ & $\begin{array}{c}\text { blau mit } \\
\text { weißlichen } \\
\text { Abschnitten }\end{array}$ & grau & & & & $\begin{array}{l}\text { Leipold und } \\
\text { Huston } \\
\text { (1968b) }\end{array}$ \\
\hline $\begin{array}{c}\text { Hereford } \\
x \\
\text { Jersey }\end{array}$ & blau & grau & $\begin{array}{c}\text { Reduktion der } \\
\text { Irispigmen- } \\
\text { tierung vor } \\
\text { allem im } \\
\text { Irisstroma, } \\
\text { unpigmen- } \\
\text { tierter Fundus, } \\
\text { RPE } \\
\text { minderpigmen- } \\
\text { tiert }\end{array}$ & Albinismus & & $\begin{array}{l}\text { Leipold und } \\
\text { Huston } \\
\text { (1968b) }\end{array}$ \\
\hline Holstein & \multicolumn{2}{|c|}{$\begin{array}{c}\text { eine Iris blau, eine normal } \\
\text { pigmentiert }\end{array}$} & & $\begin{array}{l}\text { Schwanz- } \\
\text { losigkeit }\end{array}$ & & $\begin{array}{l}\text { Huston et } \\
\text { al. (1968) }\end{array}$ \\
\hline Holstein & \multicolumn{2}{|c|}{ silber-grau } & & zum Teil blind & & $\begin{array}{l}\text { Huston et } \\
\text { al. (1968) }\end{array}$ \\
\hline $\begin{array}{c}\text { Hereford } \\
x \\
\text { Angus }\end{array}$ & & & & $\begin{array}{l}\text { Chediak- } \\
\text { Higashi- } \\
\text { Syndrom }\end{array}$ & & $\begin{array}{l}\text { Padgett et } \\
\text { al. (1967) }\end{array}$ \\
\hline Simmental & hellblau & hellbraun & $\begin{array}{l}\text { Aufhellung der } \\
\text { Fellfarbe }\end{array}$ & $\begin{array}{l}\text { Okulokutane } \\
\text { Hypopigmen- } \\
\text { tierung }\end{array}$ & $R A B 38$ & $\begin{array}{c}\text { persönliche } \\
\text { Mitteilung } \\
\text { von Jon } \\
\text { Beever }\end{array}$ \\
\hline $\begin{array}{c}\text { Wagyu } \\
\text { (Japanese } \\
\text { Black } \\
\text { cattle) }\end{array}$ & \multicolumn{2}{|c|}{ hell } & & $\begin{array}{l}\text { Chediak- } \\
\text { Higashi- } \\
\text { Syndrom }\end{array}$ & LYST & $\begin{array}{l}\text { Ogawa et } \\
\text { al. (1997); } \\
\text { Kunieda et } \\
\text { al. (2000); } \\
\text { Yamakuchi } \\
\text { et al. } \\
\text { (2000) }\end{array}$ \\
\hline
\end{tabular}

* im Text näher beschrieben 


\subsection{Ziel der Studien}

Die vorliegende Arbeit befasst sich mit der genetischen Grundlage von angeborenen Augenerkrankungen beim Rind. Im ersten Teil wurde die kongenitale Kataraktentwicklung untersucht. Seit 2009 traten mehrere Fälle von kongenitaler Katarakt bei Rindern der Rasse Holstein-Rotbunt auf. Die betroffenen Tiere waren eng miteinander verwandt, wodurch eine genetische Ursache der Kataraktentstehung sehr wahrscheinlich erschien. Ziel der Studie war es durch molekulargenetische Untersuchungen (genomweite Assoziationsstudie, genomweite Re-Sequenzierung) die genetische Ursache der Erkrankung aufzuklären.

Im Fokus der Untersuchungen des zweiten Teils der vorliegenden Studie standen Ausprägungen der bovinen Irishypopigmentierung. Dazu erfolgte eine ausführliche Definition des Phänotyps unter Ausschluss potentieller zusätzlicher Anomalien. Gestützt durch histologische Analysen sollte die iridale Pigmentreduktion qualitativ und quantitativ erfasst werden. Zudem wurde eine umfangreiche Verwandtschaftsanalyse betroffener Rinder durchgeführt. Durch molekulargenetische Techniken wie die genomweite Assoziationsstudie sollte die genetische Grundlage der iridalen Farbveränderung näher beleuchtet werden. 


\section{Literaturverzeichnis}

Ashton, Barnett, K.C., Clay, C.E. und Clegg, F.G. (1977). Congenital Nuclear Cataracts in Cattle. Vet Rec 100, 505-508.

Ayers, J.R., Leipold, H.W. und Padgett, G.A. (1988). Lesions in Brangus Cattle with Chediak-Higashi Syndrome. Vet Pathol 25, 432-436.

Bassnett, S. (2009). On the mechanism of organelle degradation in the vertebrate lens. Exp Eye Res 88(2), 133-139.

Bassnett, S. und Mataic, D. (1997). Chromatin Degradation in Differentiating Fiber Cells of the Eye Lens. J Cell Biol 137(1), 37-49.

Bergstrom, B.E., Labelle, A.L., Pryde, M.E., Hamor, R.E. und Myrna, K.E. (2014). Prevalence of Ophthalmic Disease in Blue-Eyed Horses. Equine Vet Educ 26, 438440.

Berthoud, V.M. und Beyer, E.C. (2009). Oxidative Stress, Lens Gap Junctions, and Cataracts. Antioxid Redox Signal 11, 339-353.

Bharti, K., Nguyen, M.T., Skuntz, S., Bertuzzi, S. und Arnheiter, H. (2006). The Other Pigment Cell: Specification and Development of the Pigmented Epithelium of the Vertebrate Eye. Pigment Cell Res 19, 380-394.

Bistner, S.I., Rubin, L.F. und Saunders, L.Z. (1970). The Ocular Lesions of Bovine Viral Diarrhea-Mucosal Disease. Path Vet 7, 275-286.

Brooks, B.P., Larson, D.M., Chan, C.C., Kjellstrom, S., Smith, R.S., Crawford, M.A., Lamoreux, L., Huizing, M., Hess, R., Jiao, X., Hejtmancik, J.F., Maminishkis, A., John, S.W., Bush, R. und Pavan, W.J. (2007). Analysis of Ocular Hypopigmentation in Rab38cht/cht Mice. Invest Ophthalmol Vis Sci 48, 3905-3913.

Burns, G.L., Meyers, K.M. und Prieur, D.J. (1984). Secondary Amyloidosis in a Bull with Chediak-Higashi Syndrome. Can J Comp Med 48, 113-114.

Caccamise, W.C. (1955). The Morgagnian Cataract: Its Characteristics and Surgery. Am J Ophthalmol 40, 102-106.

Carter, A.H. (1960). An Inherited Blindness (Cataract) in Cattle. Proceedings of the New Zealand Society of Animal Production 20, 108.

Cogan, D.G. (1962). Anatomy of Lens and Pathology of Cataracts. Exp Eye Res 1, 291295. 
Colombo, S., Berlin, I., Delmas, V. und Larue, L. (2011). Classical and Nonclassical Melanocytes in Vertebrates. In: Melanins and Melanosomes, Borovanský, J. und Riley, P.A. (Herausgeber), Wiley-VCH Verlag, 2011, S. 21-61.

Cvekl, A. und Tamm, E.R. (2004). Anterior Eye Development and Ocular Mesenchyme: New Insights from Mouse Models and Human Diseases. Bioessays 26, 374-386.

Detlefson, J.A. und Yapp, W.W. (1920). The Inheritance of Congenital Cataract in Cattle. The American Naturalist 54, 277-280.

Diesenhouse, M.C., Palay, D.A., Newman, N.J., To, K. und Albert, D.M. (1992). Acquired Heterochromia with Horner Syndrome in Two Adults. Ophthalmology 99, 18151817.

Eigelshoven, S., Kameda, G., Kortüm, A.K., Hübsch, S., Angerstein, W., Singh, P., Vöhringer, R., Goecke, T., Mayatepek, E., Ruzicka, T., Wildhardt, G., Meissner, T. und Kruse, R. (2009). Waardenburg Syndrome Type I with Heterochromia Iridis and Circumscribed Hypopigmentation of the Skin. Pediatr Dermatol 26, 759-761.

France, M.P. und Shaw, J.M. (1990). Blood Glucose, Calcium and Urea in Cows from a Herd with Congenital Nuclear Cataract. Vet Rec 126, 484-485.

Gahl, W.A., Brantly, M., Kaiser-Kupfer, M.I., Iwata, F., Hazelwood, S., Shotelersuk, V., Duffy, L.F., Kuehl, E.M., Troendle, J. und Bernardini, I. (1998). Genetic Defects and Clinical Characteristics of Patients with a Form of Oculocutaneous Albinism (Hermansky-Pudlak Syndrome). N Engl J Med 338, 1258-1264.

Gauly, M., Vaughan, J., Hogreve, S.K. und Erhardt, G. (2005). Brainstem Auditory-Evoked Potential Assessment of Auditory Function and Congenital Deafness in Llamas (Lama Glama) and Alpacas (L. Pacos). J Vet Intern Med 19, 756-760.

Gelatt, K.N. (1971). Cataracts in Cattle. J Am Vet Med Assoc 159, 195-200.

Gelatt, K.N. (1991): Veterinary Ophthalmology (2nd). Lea and Febiger, Philadelphia, 1991.

Gelatt, K.N. (2014): Essentials of Veterinary Ophthalmology (3rd). John Wiley \& Sons, Ames, lowa 2014.

Gelatt, K.N., Rempel, W.E., Makambera, T.P. und Anderson, J.F. (1973). Heterochromia Irides in Miniature Swine. J Hered 64, 343-347.

Graw, J. (2003). The Genetic and Molecular Basis of Congenital Eye Defects. Nat Rev Genet 4, 876-888.

Graw, J. (2004). Congenital Hereditary Cataracts. Int J Dev Biol 48, 1031-1044. 
Graw, J. (2009a). Genetics of Crystallins: Cataract and Beyond. Exp Eye Res 88, 173-189.

Graw, J. (2009b). Mouse Models of Cataract. J Genet 88, 469-486.

Graw, J. (2010). Eye Development. Curr Top Dev Biol 90, 343-386.

Gregory, P.W., Mead, S.W. und Regan, W.M. (1943). A Congenital Hereditary Eye Defect of Cattle. J Hered 34, 125-128.

Grehn, F. (2012): Augenheilkunde (31., überarb. Aufl.). Springer, Berlin 2012.

Gronskov, K., Ek, J. und Brondum-Nielsen, K. (2007). Oculocutaneous Albinism. Orphanet J Rare Dis 2, 43.

Harding, J.J. (2002). Viewing Molecular Mechanisms of Ageing through a Lens. Ageing Res Rev 1, 465-479.

Harris, J.E. und Becker, B. (1965). Cation Transport of the Lens. Invest Ophthalmol 4, 709722.

Hässig, M., Jud, F. und Spiess, B. (2012). Increased Occurrence of Nuclear Cataract in the Calf after Erection of a Mobile Phone Base Station. Schweizer Archiv für Tierheilkunde 154, 82-86.

Hejtmancik, J.F. (2008). Congenital Cataracts and Their Molecular Genetics. Semin Cell Dev Biol 19, 134-149.

Ho, M.C. und Hsieh, Y.T. (2013). Mixed Hyperpigmentation and Hypopigmentation of Iris and Choroid in Chediak-Higashi Syndrome. J AAPOS 17, 558-560.

Hodge, W.G., Whitcher, J.P. und Satariano, W. (1995). Risk Factors for Age-Related Cataracts. Epidemiol Rev 17, 336-346.

Hof, K. A. (2015): Klinische, pathomorphologische und sonographische Untersuchungen am Rinderauge. Dissertation Freie Universität Berlin. Abrufbar unter: http://www.diss.fu-berlin.de/diss/receive/FUDISS_thesis_000000101076.

Horwitz, J. (1992). Alpha-Crystallin Can Function as a Molecular Chaperone. Proc Natl Acad Sci USA. 89, 10449-10453.

Horwitz, J. (2003). Alpha-Crystallin. Exp Eye Res 76, 145-153.

Hurley, S. (2008). Blind but Healthy Calves. Vet Rec 163, 579.

Huston, K., Leipold, H.W. und Freeman, A.E. (1968). Heterochromia Irides in Dairy Cattle. J Dairy Sci 51, 1101-1102. 
Introne, W., Boissy, R.E. und Gahl, W.A. (1999). Clinical, Molecular, and Cell Biological Aspects of Chediak-Higashi Syndrome. Mol Genet Metab 68, 283-303.

Jackling, F.C., Johnson, W.E. und Appleton, B.R. (2014). The Genetic Inheritance of the Blue-Eyed White Phenotype in Alpacas (Vicugna Pacos). J Hered 105, 847-857.

Jayasekera, U. und Leipold, H.W. (1981). Albinism in United-States Charolais Cattle. Ann Genet Sel Anim 13, 213-218.

Krump, L., O'Grady, L., Lorenz, I. und Grimes, T. (2014). Congenital Cataracts in an Ayrshire Herd: A Herd Case Report. Ir Vet J 67, 2.

Kunieda, T., Ide, H., Nakagiri, M., Yoneda, K., Konfortov, B. und Ogawa, H. (2000). Localization of the Locus Responsible for Chediak-Higashi Syndrome in Cattle to Bovine Chromosome 28. Anim Genet 31, 87-90.

Lang, R. (1995). The Occurence and Possible Inheritance of Heterochromia Irides in a Merino Flock. Proc Assoc Advmt Anim Breed Genet 11, 323-325.

Lang, R. (1999). The Most Likely Inheritance of Heterochromla Irides in a Merino Flock. Proc Adv Anim BreedGen 13, 444-447.

Leipold, H.W. und Huston, K. (1966). A Herd of Glass-Eyed Albino Hereford Cattle. J Hered 57, 179-182.

Leipold, H.W. und Huston, K. (1968a). Incomplete Albinism and Heterochromia Irides in Herefords. J Hered 59, 3-8.

Leipold, H.W. und Huston, K. (1968b). Dominant Incomplete Albinism of Cattle. J Hered 59, 223-224.

Leipold, H.W. und Huston, K. (1969). Histopathology of Incomplete Albinism and Heterochromia Irides in the Hereford. Cornell Vet 59, 69-75.

Leipold, H.W., Huston, K. und Gelatt, K.N. (1968). Complete Albinism in a Guernsey Calf. J Hered 59, 218-220.

Liu, F., van Duijn, K., Vingerling, J.R., Hofman, A., Uitterlinden, A.G., Janssens, A.C. und Kayser, M. (2009). Eye Color and the Prediction of Complex Phenotypes from Genotypes. Curr Biol 19, R192-193.

Loftus, S.K., Larson, D.M., Baxter, L.L., Antonellis, A., Chen, Y., Wu, X., Jiang, Y., Bittner, M., Hammer, J.A. 3rd und Pavan, W.J. (2002). Mutation of Melanosome Protein RAB38 in Chocolate Mice. Proc Natl Acad Sci USA 99, 4471-4476. 
Lühken, G., Fleck, K., Pauciullo, A., Huisinga, M. und Erhardt, G. (2012). Familiar Hypopigmentation Syndrome in Sheep Associated with Homozygous Deletion of the Entire Endothelin Type-B Receptor Gene. Plos One 7 (12): e53020.

Mackay, D., Ionides, A., Kibar, Z., Rouleau, G., Berry, V., Moore, A., Shiels, A. und Bhattacharya, S. (1999). Connexin46 Mutations in Autosomal Dominant Congenital Cataract. Am J Hum Genet 64, 1357-1364.

Magalhaes, H., Martin, J.R. und Loan, E.L. (1962). Heterochromia Iridis in the Golden Hamster (Mesocricetus-Auratus). Am Zool 2, 537.

Magdesian, K.G., Williams, D.C., Aleman, M., Lecouteur, R.A. und Madigan, J.E. (2009). Evaluation of Deafness in American Paint Horses by Phenotype, Brainstem Auditory-Evoked Responses, and Endothelin Receptor B Genotype. J Am Vet Med Assoc 235, 1204-1211.

Marks, M.S. und Seabra, M.C. (2001). The Melanosome: Membrane Dynamics in Black and White. Nat Rev Mol Cell Biol 2, 738-748.

Michael, R. und Bron, A.J. (2011). The Ageing Lens and Cataract: A Model of Normal and Pathological Ageing. Philos Trans R Soc Lond B Biol Sci 366, 1278-1292.

Misk, N.A., Semieka, M.A. und Fathy, A. (1998). Heterochromia Iridis in Water Buffaloes (Bubalus Bubalis). Vet Ophthalmol 1, 195-201.

Murgiano, L., Jagannathan, V., Calderoni, V., Joechler, M., Gentile, A. und Drögemüller, C. (2014). Looking the Cow in the Eye: Deletion in the NID1 Gene Is Associated with Recessive Inherited Cataract in Romagnola Cattle. PLoS One 9, e110628.

Na, K.S., Park, Y.G., Han, K., Mok, J.W. und Joo, C.K. (2014). Prevalence of and Risk Factors for Age-Related and Anterior Polar Cataracts in a Korean Population. PLoS One 9, e96461.

Ogawa, H., Tu, C.H., Kagamizono, H., Soki, K., Inoue, Y., Akatsuka, H., Nagata, S., Wada, T., Ikeya, M., Makimura, S., Uchida, K., Yamaguchi, R. und Otsuka, H. (1997). Clinical, Morphologic, and Biochemical Characteristics of Chediak-Higashi Syndrome in Fifty-Six Japanese Black Cattle. Am J Vet Res 58, 1221-1226.

Ollivier, L. und Sellier, P. (1982). Pig Genetics - a Review. Ann Genet Sel Anim 14, 481544.

Padgett, G.A., Leader, R.W., Gorham, J.R. und O'Mary, C.C. (1964). The Familial Occurrence of the Chediak-Higashi Syndrome in Mink and Cattle. Genetics 49, 505-512.

Padgett, G.A., Reiquam, C.W., Gorham, J.R., Henson, J.B. und O'Mary, C.C. (1967). Comparative Studies of the Chediak-Higashi Syndrome. Am J Pathol 51, 553-571. 
Philipp, U., Lupp, B., Momke, S., Stein, V., Tipold, A., Eule, J.C., Rehage, J. und Distl, O. (2011). A MITF Mutation Associated with a Dominant White Phenotype and Bilateral Deafness in German Fleckvieh Cattle. Plos One 6 (12): e28857.

Raposo, G., Tenza, D., Murphy, D.M., Berson, J.F. und Marks, M.S. (2001). Distinct Protein Sorting and Localization to Premelanosomes, Melanosomes, and Lysosomes in Pigmented Melanocytic Cells. J Cell Biol 152, 809-824.

Reddy, V.N. (1979). Dynamics of Transport Systems in the Eye. Friedenwald Lecture. Invest Ophthalmol Vis Sci 18, 1000-1018.

Renard, D., Jeanjean, L. und Labauge, P. (2010). Heterochromia Iridis in Congenital Horner's Syndrome. Eur Neurol 63, 253.

Rennie, I.G. (2012). Don't It Make My Blue Eyes Brown: Heterochromia and Other Abnormalities of the Iris. Eye (Lond) 26, 29-50.

Rowett, M.A. und Fleet, M.R. (1993). Albinism in a Suffolk Sheep. J Hered 84, 67-69.

Saunders, L.Z. und Fincher, M.G. (1951). Hereditary Multiple Eye Defects in Grade Jersey Calves. Cornell Vet 41, 351-366.

Schmidt, V. (1973): Augenkrankheiten der Haustiere. Fischer, Jena 1973.

Schwab, I.R. (1990). Fuchs' Heterochromic Iridocyclitis. Int Ophthalmol Clin 30, 252-256.

Seiji, M., Fitzpatrick, T.B., Simpson, R.T. und Birbeck, M.S. (1963). Chemical Composition and Terminology of Specialized Organelles (Melanosomes and Melanin Granules) in Mammalian Melanocytes. Nature 197, 1082-1084.

Shichi, H. (2004). Cataract Formation and Prevention. Expert Opin Investig Drugs 13, 691-701.

Shields, C.L., Nickerson, S.J., Al-Dahmash, S. und Shields, J.A. (2013). Waardenburg Syndrome: Iris and Choroidal Hypopigmentation: Findings on Anterior and Posterior Segment Imaging. JAMA Ophthalmol 131, 1167-1173.

Shiels, A. und Hejtmancik, J.F. (2007). Genetic Origins of Cataract. Arch Ophthalmol 125, 165-173.

Shiels, A. und Hejtmancik, J.F. (2013). Genetics of Human Cataract. Clin Genet 84, 120127.

Shiels, A. und Hejtmancik, J.F. (2015). Chapter Twelve - Molecular Genetics of Cataract. In: Progress in Molecular Biology and Translational Science, Hejtmancik, J.F. und John, M.N. (Herausgeber), Academic Press, 2015, S. 203-218. 
Shiels, A., Bennett, T.M. und Hejtmancik, J.F. (2010). Cat-Map: Putting Cataract on the Map. Mol Vis 16, 2007-2015.

Shiels, A., Mackay, D. und Bennett, T. (2016). Cat-Map. http://cat-map.wustl.edu (aufgerufen am 2016/12/01).

Shiels, A., Mackay, D., lonides, A., Berry, V., Moore, A. und Bhattacharya, S. (1998). A Missense Mutation in the Human Connexin50 Gene (GJA8) Underlies Autosomal Dominant "Zonular Pulverulent" Cataract, on Chromosome 1q. Am J Hum Genet $62,526-532$.

Shiraishi, M., Ogawa, H., Ikeda, M., Kawashima, S. und Ito, K. (2002). Platelet Dysfunction in Chediak-Higashi Syndrome-Affected Cattle. J Vet Med Sci 64, 751-760.

Shively, J.N. und Phemister, R.D. (1968). Fine Structure of the Iris of Dogs Manifesting Heterochromia Iridis. Am J Ophthalmol 66, 1152-1162.

Sitaram, A. und Marks, M.S. (2012). Mechanisms of Protein Delivery to Melanosomes in Pigment Cells. Physiology (Bethesda) 27, 85-99.

Slingsby, C., Wistow, G.J. und Clark, A.R. (2013). Evolution of Crystallins for a Role in the Vertebrate Eye Lens. Protein Sci 22, 367-380.

Small, C.P. (1919). Hereditary Cataract in Calves. American Journal of Ophthalmology 2, 681-682.

Sparrow, J.M., Bron, A.J., Brown, N.A., Ayliffe, W. und Hill, A.R. (1986). The Oxford Clinical Cataract Classification and Grading System. Int Ophthalmol 9, 207-225.

Stevens, A. und Lowe, J.S. (1992): Histologie. Übersetzt und bearbeitet von Klaus Tiedemann. VCH, Weinheim, Basel 1992.

Stritzel, S., Wöhlke, A. und Distl, O. (2009). A Role of the Microphthalmia-Associated Transcription Factor in Congenital Sensorineural Deafness and Eye Pigmentation in Dalmatian Dogs. J Anim Breed Genet 126, 59-62.

Tamilmahan, P., Zama, M.M.S., Pathak, R., N. S. Muneeswaran, N.S. und Karthik, K. (2013). A Retrospective Study of Ocular Occurrence in Domestic Animals: 799 Cases. Vet World 6, 274-276.

Thibos, L.N., Levick, W.R. und Morstyn, R. (1980). Ocular Pigmentation in White and Siamese Cats. Invest Ophthalmol Vis Sci 19, 475-486.

Trantow, C.M., Mao, M., Petersen, G.E., Alward, E.M., Alward, W.L., Fingert, J.H. und Anderson, M.G. (2009). Lyst Mutation in Mice Recapitulates Iris Defects of Human Exfoliation Syndrome. Invest Ophthalmol Vis Sci 50, 1205-1214. 
Ushigusa, T., Uchida, K., Murakami, T., Yamaguchi, R. und Tateyama, S. (2000). A Pathologic Study on Ocular Disorders in Calves in Southern Kyushu, Japan. J Vet Med Sci 62, 147-152.

Vasconcelos, D.Y. und Grahn, B.H. (1995). Disseminated Rhizopus Infection with Ocular Involvement in a Calf. Vet Pathol 32, 78-81.

Vogel, P., Read, R.W., Vance, R.B., Platt, K.A., Troughton, K. und Rice, D.S. (2008). Ocular Albinism and Hypopigmentation Defects in Slc24a5-/- Mice. Vet Pathol 45, 264279.

West, S.K. und Valmadrid, C.T. (1995). Epidemiology of Risk Factors for Age-Related Cataract. Surv Ophthalmol 39, 323-334.

Yamaguchi, Y. und Hearing, V.J. (2009). Physiological factors that regulate skin pigmentation. BioFactors (Oxford, England), 35 (2), 193-199.

Yamaguchi, Y. und Hearing, V.J. (2014). Melanocytes and Their Diseases. Cold Spring Harb Perspect Med 4 (5):a017046.

Yamakuchi, H., Agaba, M., Hirano, T., Hara, K., Todoroki, J., Mizoshita, K., Kubota, C., Tabara, N. und Sugimoto, Y. (2000). Chediak-Higashi Syndrome Mutation and Genetic Testing in Japanese Black Cattle (Wagyu). Anim Genet 31, 13-19.

Yi, J., Yun, J., Li, Z.K., Xu, C.T. und Pan, B.R. (2011). Epidemiology and Molecular Genetics of Congenital Cataracts. Int J Ophthalmol 4, 422-432. 


\section{KAPITEL 2}

Morgagnian cataract resulting from a naturally occurring nonsense mutation elucidates a role of CPAMD8 in mammalian lens development

veröffentlicht in:

PLOS ONE

12(7): e0180665

DOI: 10.1371/journal.pone.0180665

URL: https://doi.org/10.1371/journal.pone.0180665 
Morgagnian cataract resulting from a naturally occurring nonsense mutation elucidates a role of CPAMD8 in mammalian lens development

\section{Morgagnian cataract resulting from a naturally occurring nonsense mutation elucidates a role of CPAMD8 in mammalian lens development}

Anne K. Hollmann ${ }^{1}$, Insa Dammann², Wiebke M. Wemheuer ${ }^{3}$, Wilhelm E. Wemheuer ${ }^{1}$, Almuth Chilla ${ }^{1}$, Andrea Tipold ${ }^{4}$, Walter J. Schulz-Schaeffer ${ }^{3}$, Julia Beck ${ }^{5}$, Ekkehard Schütz ${ }^{1}$ \& Bertram Brenig ${ }^{1}$

${ }^{1}$ University of Goettingen, Institute of Veterinary Medicine, Goettingen, Germany

${ }^{2}$ University Medical Center Goettingen, Department of Neuropathology, Prion and Dementia Research Unit, Goettingen, Germany

${ }^{3}$ University of the Saarland, Institute of Neuropathology, Homburg, Germany

4 University of Veterinary Medicine Hannover, Foundation, Department of Small Animal Medicine and Surgery, Hannover, Germany

${ }^{5}$ Chronix Biomedical, Goettingen, Germany

\section{PLOS ONE}

12(7): e0180665

DOI: 10.1371/journal.pone.0180665

URL: https://doi.org/10.1371/journal.pone.0180665 


\section{Abstract}

To investigate the genetic basis of hereditary lens opacities we analyzed 31 cases of bilateral congenital cataract in Red Holstein Friesian cattle. A genome-wide association study revealed a significant association on bovine chromosome 7 at positions $6,166,179$ and $12,429,691$. Whole genome re-sequencing of one case and four relatives showed a nonsense mutation (g.5995966C>T) in the PZP-like, alpha-2-macroglobulin domain containing 8 (CPAMD8) gene leading to a premature stop codon (CPAMD8 p.Gln74*) associated with cataract development in cattle. With immunohistochemistry we confirmed a physiological expression of CPAMD8 in the ciliary body epithelium of the eye in unaffected cattle, while the protein was not detectable in the ciliary body of cattle with cataracts. RNA expression of CPAMD8 was detected in healthy adult, fetal and cataractous lenses.

\section{Introduction}

Cataracts are opacities of the lens present from birth (congenital) or acquired during life and are the main cause of blindness in humans worldwide [1]. The genetic background of the disease is well studied in humans. Until today more than 290 genes and 19 nongene loci have been associated with cataract development in humans and mice [2]. Besides hereditary cataracts, opacities also occur as part of multisystemic disorders or due to the impact of environmental factors [3]. In cattle knowledge about the etiology of cataract development (due to genetic or environmental factors) is still relatively scarce, even though an incidence of $26 \%$ was reported in some herds [4]. Cataracts have already been observed in several cattle breeds, such as Holstein Friesian [5-8], Jersey [9, 10], Hereford [11], Aberdeen Angus [11], Shorthorn [11] and Ayrshire [4]. So far, only one mutation with recessive inheritance has been identified leading to juvenile-onset bilateral incomplete immature nuclear cataract in Romagnola cattle [12].

Many of the identified mutations leading to cataract development in humans and mice affect genes encoding lens crystallins and have been discussed in detail elsewhere [13]. Mutations in other proteins like membrane, cytoskeleton and gap junction proteins, 
beaded filaments, growth and transcriptional factors are also known to result in cataract development [3, 14]. Recently, C3 and PZP-like, alpha-2-macroglobulin domaincontaining 8 gene (CPAMD8), a so-far unknown candidate gene for cataract development, was associated with anterior segment dysgenesis (ASD). ASD manifests itself in a spectrum of developmental abnormalities affecting the anterior segment of the eye, including cataract [15]. CPAMD8 belongs to the complement component 3 (C3)/alpha2-macroglobulin (A2M) family [16], whose members are involved in the innate immune system $[17,18]$. Except for the association with ASD, knowledge about the biological function of CPAMD8 is comparatively scanty. The gene was discussed as being associated with Ashkenazi Jewish Crohn's disease [19] and multiple sclerosis [20] in humans. Regarding eye development, CPAMD8 expression was observed to be upregulated in the regeneration-incompetent irides of axolotls [21].

Since 2009, congenital cataracts have been increasingly reported in German Red Holstein Friesian (HF) cattle. A total of 31 cases were observed, and they have provided the opportunity to elucidate the molecular cause of the disorder. As a result we have detected a nonsense mutation in CPAMD8 (g.5995966C>T) leading to a premature stop codon in exon 1 of the gene associated with congenital cataract development in $\mathrm{HF}$ cattle.

\section{Results}

\section{Clinical findings}

All four examined cases showed bilateral complete mature cataracts at time of birth. No other obvious ophthalmological anomalies were observed at this timepoint.

Eyes of the affected female cattle were examined in detail with the appropriate ophthalmologic equipment at approximately either 13 or 30 months of age (S1 Table). All cases showed a mature to hypermature cataract at time of examination (Fig 1A-1E). Besides the opacities, mydriasis and microphakia (mostly accompanied by an irregular shape of the lens), multiple eye defects like posterior synechia, glaucoma, exophthalmos, uveitis and retinitis (in one case) were additionally observed in some eyes (for details see S1 Table). These anomalies developed during life of cataract cases 
Morgagnian cataract resulting from a naturally occurring nonsense mutation elucidates a role of CPAMD8 in mammalian lens development

and were not congenital. The ongoing dissolution of the lens and subsequent inflammatory processes affecting the eye are suspected to be the reason for these clinical findings. In all but one eye the ocular fundus appeared to be free of pathological findings. Anomalies as iris hypoplasia, corectopia and ectropion uveae as observed by Cheong et al. (2016) were not detected. Neurological examination did not show any deficits other than the ones related to the bilateral eye problem.

\section{Pathology and histopathology}

Since the complete eyeballs were fixed in formalin before they were cut for histology, the visual inspection of the inner eye was performed on fixed tissue. Lenses were usually of irregular shape, about two-thirds to half the size of an unaffected lens, and opaque white (Fig 1A-1E). Microphakia was more pronounced in two of the older animals (\#908 (Fig 1E) and \#489 (Fig 1D), 30 and 31.5 months of age). Histologically, the regular lens would consist of a cuboidal epithelium in its anterior parts (Fig $1 \mathrm{~F}$ arrow) that turns at the equatorial line, loses its nuclei and cytoplasmatic organelles and degrades to lens fibers, building the bulk of the lens. The lens epithelium usually has a thick basement membrane, forming a capsule (Fig 1F). The cataractous lenses showed a loss of lens epithelium and thickening of the capsule (Fig $1 \mathrm{G}$ and $1 \mathrm{H}$ ), but no clear distinction between basement membrane and connective tissue. The bulk of the lens showed Morgagnian globules (Fig $1 \mathrm{G}$ and $1 \mathrm{I}$ ), liquefactions and mineralizations (not shown) confirming the presence of a hypermature cataract. No fibrillary structures could be observed. 
Morgagnian cataract resulting from a naturally occurring nonsense mutation elucidates a role of CPAMD8 in mammalian lens development
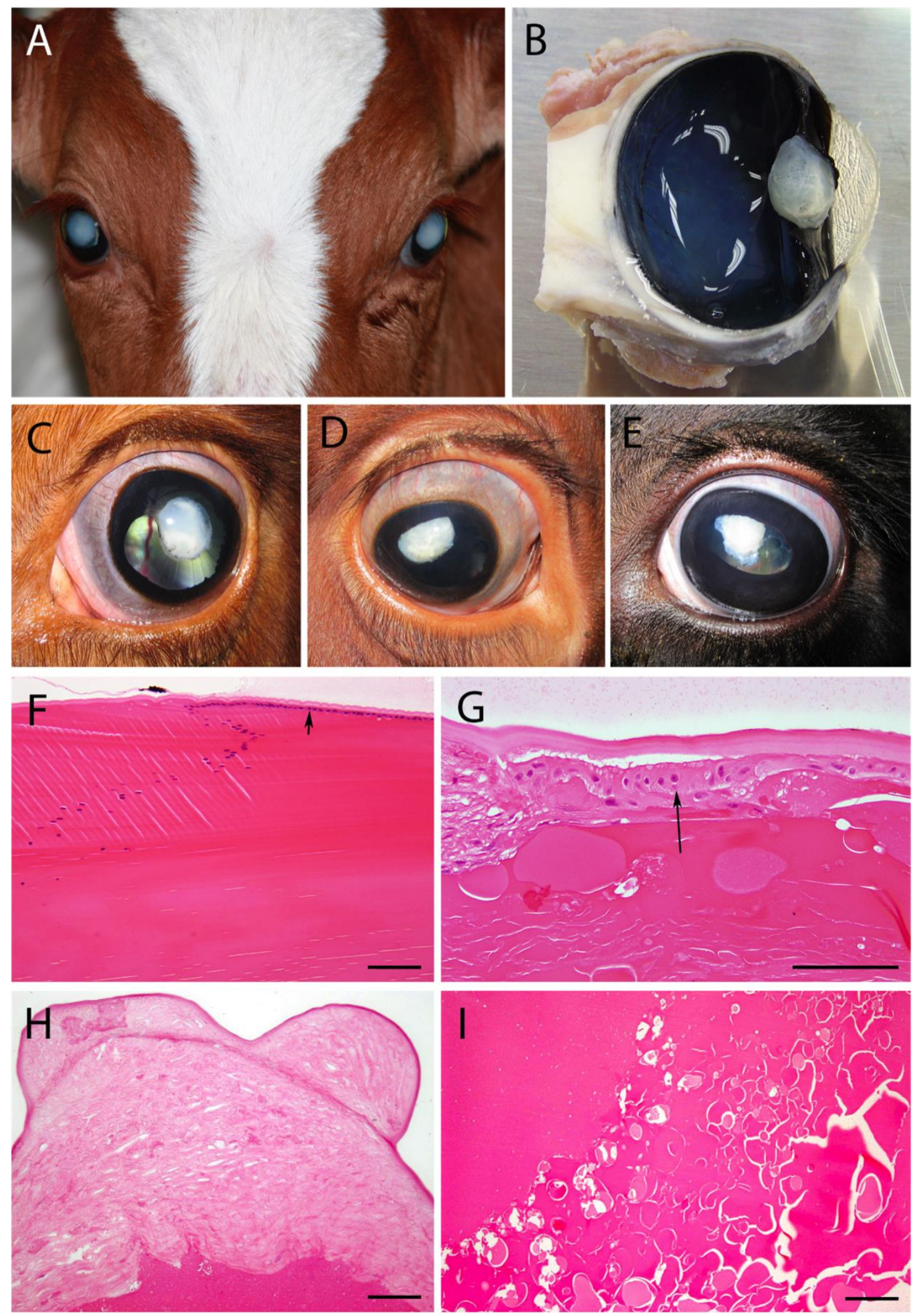

Fig 1. Congenital cataract in Red Holstein Friesian cattle.

(A) Bilateral mature cataract formation, (B) sagittal cut through the eyeball (formalin fixed) with cataractous lens (animal \#224) clearly showing the irregular lens surface. (C) to $(E)$ are pictures of different stages of the degenerative lenses in situ taken during the 
clinical examinations: (C) left eye of animal \#227 at 13 months, mature cataract, (D) right eye of animal \#489 at 31.5 months, mature to hypermature cataract, (E) left eye of animal \#908 at 30 months, mature to hypermature cataract. Iris abnormalities as observed by Cheong et al. (2016) in human ASD patients showing cataracts were not detected in bovine cataract cases. (F) to (I) show the histopathological changes in hematoxylin/eosin stained sections (bars $=100 \mu \mathrm{m}$ ): $(\mathrm{F})$ lens equatorial line in a bovine healthy adult lens where the anterior epithelium (arrow) under the capsule is clearly visible (control animal). During cataract formation the capsule thickens, the cuboidal epithelium (G, arrow, animal \#224, left eye) disintegrates and over time vanishes completely ( $\mathrm{H}$, animal \#908, left eye). The loss of lens fibrils and presence of Morgagnian globules indicate the presence of a hypermature cataract ( $G, I$, animal \#224). Fig $1 A$ was digitally improved and cropped using GIMP 2.8.18.

\section{Autosomal recessive inheritance of congenital cataract formation}

Analysis of the pedigree data revealed that 26 of 31 cases were paternal half-siblings of sire \#870 (Fig 2). In 20 of 31 cases, the dams' fathers were either sires \#053, \#890 or \#977. The four sires \#870, \#053, \#890 and \#977 shared one common ancestor (\#780) two to three generations before. Sire \#780, born in 1982, appeared in 28 of 31 cases in the dam and sire line of the pedigrees. Pedigrees of the remaining three animals were not clearly documented. Parental testing was not performed. However, an autosomal recessive inheritance of the cataract phenotype can be inferred from pedigree analyses, although a relation to the predicted founder (\#780) on the dam's side could not be verified in three cases. Sire \#780 was genotyped as a carrier and is most likely the founder of the defect. 


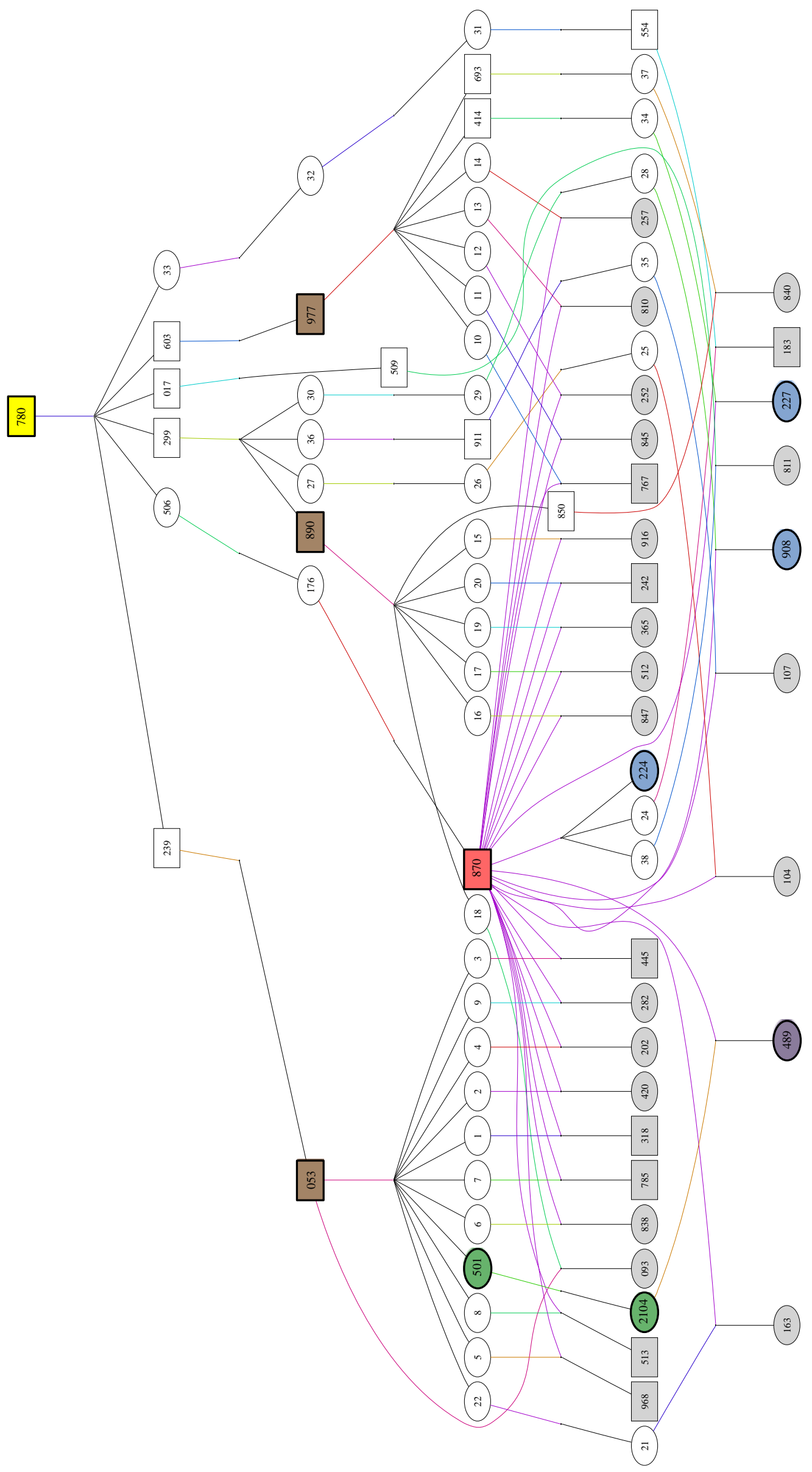




\section{Fig 2. Origin and transmission of cataract in Red Holstein Friesian cattle.}

The pedigree depicts the ancestry of the affected individuals (grey, purple and blue symbols). Two cases are not displayed in the family tree. Neither maternal nor paternal lines were clearly documented. Animal \#183 was also genotyped T/T for the variant g.5995966C $>\mathrm{T}$ in CPAMD8. The origin of the cataract-causing mutation was traced back to founder sire \#780 (yellow symbol). The dam's sires in 20 of 31 cases were sires \#053, \#890, \#977, marked with brown symbols. The red symbol shows sire \#870, father of 26 of 31 cases. This animal (\#870) was also used for whole genome re-sequencing, as the green (mother and maternal grandmother of one case) and purple (cattle with congenital cataract) marked cattle. The blue and purple symbols mark the four dissected cases. Family tree was created using Pedigraph [22].

\section{Association and region of extended homozygosity on bovine chromosome 7 (BTA7)}

Case-control analysis of 26 cases and 88 controls revealed an association with the cataract phenotype on bovine chromosome 7 (BTA7) ( $p$ values: 4.41×10-37 (Bonferroniadjusted $p$ value: $1.85 \times 10^{-32}$ ) at position $12,429,691$ and $1.30 \times 10^{-34}$ (Bonferroni-adjusted $p$ value: $5.44 \times 10^{-30}$ ) at position $6,166,179$ ) (all positions refer to assembly UMD_3.1)

(Fig 3). Regarding the proposed autosomal recessive inheritance, we searched for regions of extended homozygosity in cases of congenital cataracts. A 4.7 Mb interval from 5,639,104 to 10,406,009 on BTA7 (UMD_3.1) was detected harboring 76 SNPs. Due to the positional overlap of the association on BTA7 and the region of homozygosity on BTA7, we searched for positional and functional candidate genes within this region. However, none of the 166 annotated genes located in the region of extended homozygosity had so far been associated with congenital cataract. 
Morgagnian cataract resulting from a naturally occurring nonsense mutation elucidates a role of CPAMD8 in mammalian lens development

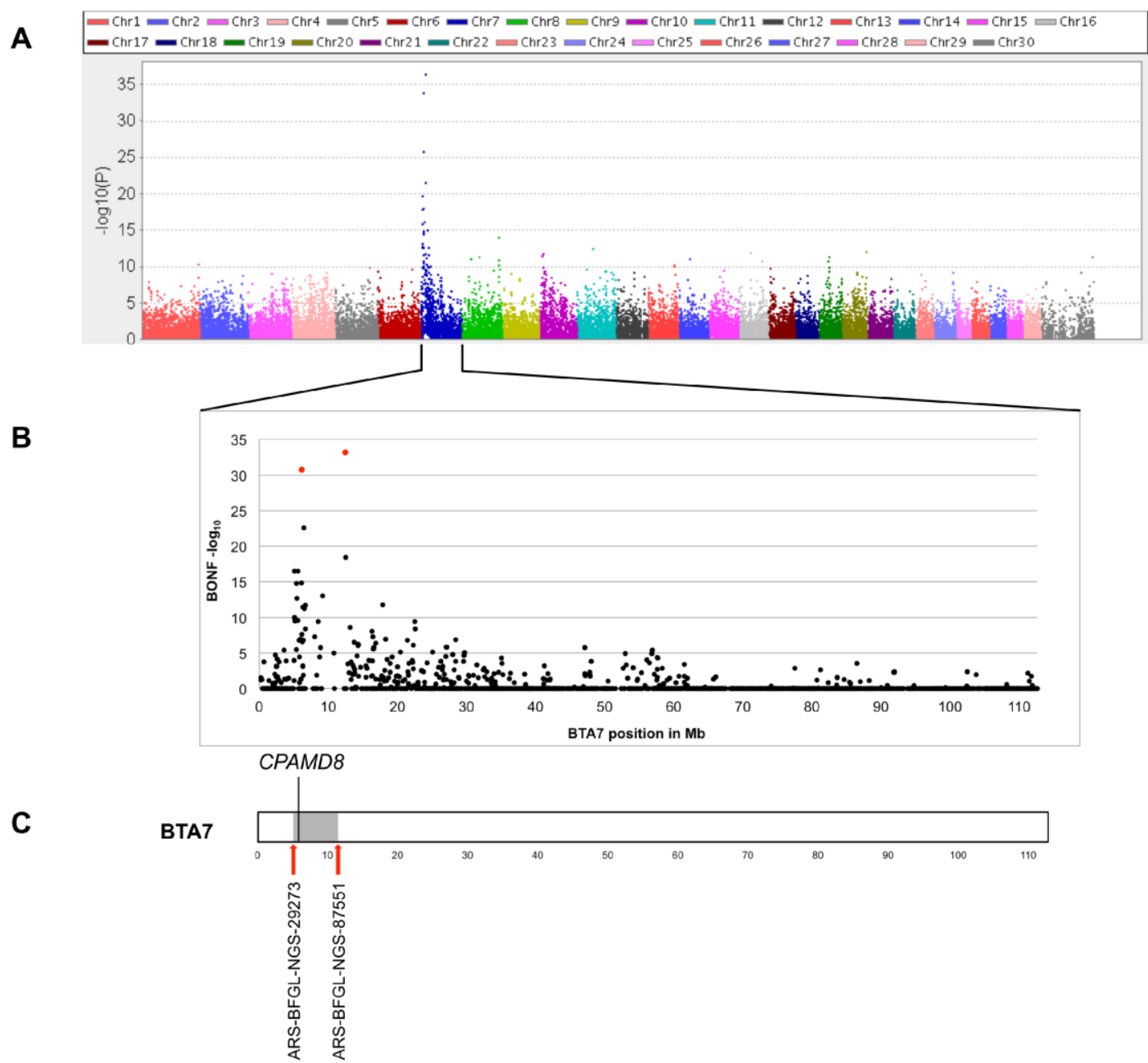

Fig 3. Results of genome-wide association study (GWAS) using SNP data of $\mathbf{2 6}$ cases and 88 Holstein control animals.

(A) Manhattan plot (generated using Haploview [23]) and calculated $-\log _{10} p$ values showing an association with the cataract phenotype on BTA7, (B) Detailed view of association on BTA7 with $-\log _{10}$ Bonferroni-adjusted $p$ values. Red symbols showing associations of $5.44 \times 10^{-30}$ at position $6,166,179$ and $1.85 \times 10^{-32}$ at position $12,429,691$, (C) Region of extended homozygosity on BTA7 in cataract cases (grey symbol). CPAMD 8 $(5,995,747$ to $6,095,877)$ is located at the proximal end of the $4.7 \mathrm{Mb}$ region of extended homozygosity from $5,639,104$ to $10,406,009$. 


\section{Whole genome re-sequencing and identification of a variant in the CPAMD8 gene associated with congenital cataract formation in cattle}

Due to the lack of functional candidate genes in the associated region on BTA7, a whole genome re-sequencing was performed. Based on the pedigree analysis two trios were sequenced. The first trio consisted of one case (\#489, Fig 1D) and its parents (\#870 and $\# 2104)$. The second trio included the grandmother (\#501) and a cross between the grandmother \#501 and the father \#870 of this case \#489. 2019 variants in the homozygous state were called for the affected animal in the associated interval from 4 to $13 \mathrm{Mb}$ on BTA7. The detected variants were filtered for their predicted effect on the amino acid sequence. Seven variants with non-synonymous coding and one variant leading to a premature stop codon remained after filtering. Six of seven variants with non-synonymous coding affected olfactory receptors (olfactory receptor $10 \mathrm{H} 1$-like, $10 \mathrm{H} 1$ and $10 \mathrm{H} 4)$ and were excluded from further analysis due to their biological function. Remaining variants in GTPBP3 (GTP binding protein 3, g.5711730T>C) and CPAMD8 (C3 and PZP like, alpha-2-macroglobulin domain containing 8, g.5995966C>T; positions refer to accession number AC_000164.1, UMD_3.1) were validated by PCR and subsequent melting curve analysis using FRET technology. The only variant that remained perfectly associated with the cataract phenotype was the chain termination mutation detected in CPAMD8 (g.5995966C>T). CPAMD8 is located from 5,995,747 to 6,095,877 on BTA7 (UMD_3.1, AC_000164.1) and contains 42 exons. The gene is located at the proximal end of the detected region of extended homozygosity on BTA7 and at a distance of around $70 \mathrm{~kb}$ from a SNP at position 6,166,179 (Bonferroni-adjusted $\mathrm{p}$ value of $5.44 \times 10^{-30}$, UMD_3.1, AC_000164.1), which was identified previously by GWAS. The identified variant g.5995966C $>$ T was located within the first exon of the CPAMD8 gene at position c.220 (UMD_3.1) and has not yet been described. The nonsense mutation p.GIn74* results in a null allele. Homozygous mutant cases therefore lack CPAMD8 protein. 
Morgagnian cataract resulting from a naturally occurring nonsense mutation elucidates a role of CPAMD8 in mammalian lens development

\section{Genotyping of variant g.5995966C $>$ T}

Genotyping of 1,248 animals was performed to verify the variant g.5995966C $>T$ in CPAMD8 (Table 1). All animals with cataract phenotype $(n=31)$ were tested T/T. In total 161 cattle were genotyped $C / T$, including the parents of affected cattle. 1,055 randomly tested control animals were tested homozygous $\mathrm{C} / \mathrm{C}$. All pedigrees of heterozygous animals showed an inheritance with the predicted founder, sire \#780.

Besides the 31 tested cataract cases, there was an additional animal (\#183) genotyped T/T. Unfortunately, the phenotype of the animal was unknown, since it had already been culled by the time of genotyping. However, the father (\#554) and the maternal grandfather (\#870) of \#183 were tested heterozygous C/T and were related to sire \#780.

Table 1. Detection of CPAMD8 g.5995966C >T in different cattle breeds.

\begin{tabular}{|c|c|}
\hline Genotype & No. of cattle \\
\hline T/T & $32^{\text {a) }}$ \\
\hline C/T & $161^{\text {b) }}$ \\
\hline C/C & $1,055^{\text {c) }}$ \\
\hline total & 1,248 \\
\hline
\end{tabular}

a) The $32 \mathrm{~T} / \mathrm{T}$ individuals include 31 cases and one HF animal with unknown phenotype (\#183). Both parents of \#183 were tested heterozygous C/T and were related to the predicted founder sire \#780.

b) All heterozygous tested HF cattle were related to sire \#780.

c) The 1,055 C/C individuals include 1,046 HF and nine animals of other breeds, i.e. Angus, Charolais, Jersey, Limousin, White Galloway. 
Morgagnian cataract resulting from a naturally occurring nonsense mutation elucidates a role of CPAMD8 in mammalian lens development

\section{RNA expression of bovine CPAMD8}

RNA was extracted from the lenses of three animals, one with cataract (mature to hypermature cataract, \#489), one adult control and one fetal control animal. Furthermore, lung and thyroid gland tissues from two animals, one with cataract (\#489) and one adult control animal, were used as control samples (Table 2). Other ocular tissue samples were not considered. Except for cataracts, observed ocular anomalies were not congenital. Anomalies as listed in S1 Table, developed due to ongoing lens dissolution and subsequent inflammatory processes affecting the eyes of cataract cases. Due to the physiological condition of the other ocular structures, these tissues were not considered for RNA analyses. Although RNA from cataractous and adult lens extracts showed low RNA quality (RIN factors $<6$ ), CPAMD8 RNA was detected in all tested tissue samples. However, an exact quantification relative to the reference gene was not possible. Despite the low quality, CPAMD8 RNA was detectable in lens materials of cataractous, fetal and healthy adult lenses.

Annotation of CPAMD8 is based on assembly UMD_3.1, AC_000164.1. Expression of corresponding isoforms was tested by PCR for lens tissue. There was no indication of expression of alternative isoforms as e.g. ENSBTAP00000036263, annotated in Ensembl database. 
Table 2. Tissue samples for RNA analyses of CPAMD8, including ddPCR results and RNA integrity number (RIN) from RNA quality measurement using RNA 6000 Pico Kit (Agilent Technologies, Waldbronn, Germany).

\begin{tabular}{|l|c|c|c|}
\hline Tissue samples & RIN & $\begin{array}{c}\text { Mean copy } \\
\text { numbers CPAMD8 } \\
\left(\text { CV }^{1}\right)\end{array}$ & $\begin{array}{c}\text { Mean copy } \\
\text { numbers GAPDH } \\
\left(\text { CV }^{1}\right)\end{array}$ \\
\hline Lung-healthy control & 7.4 & $23.3(0.107)$ & $99(0.0808)$ \\
\hline Thyroid gland-healthy control & 6.9 & $11.5(0.260)$ & $1442.5(0.0947)$ \\
\hline Lung case & 8.3 & $59.5(0.032)$ & $127(0.0394)$ \\
\hline Thyroid gland case & 7.4 & $8.2(0.012)$ & $228(0.0263)$ \\
\hline Adult healthy lens & 2.4 & $0.125(0.360)$ & $120.5(0.0622)$ \\
\hline Fetal lens & 7.1 & $0.665(0.0226)$ & $597.5(0.0410)$ \\
\hline Cataractous lens & 1 & $0.023(0.231)$ & $0.32(0.0625)$ \\
\hline
\end{tabular}

1) $C V=$ Coefficient of variation

\section{Immunohistochemical detection of CPAMD8}

In healthy fetal and adult control cattle, CPAMD8 was detectable by immunohistochemistry in the epithelium of the ciliary body, where the staining was related to intracytoplasmic organelles (Fig 4B). In contrast, in the ciliary body epithelium of cataract cases, no CPAMD8 immunoreaction was detectable (Fig 4C). In cataract and control cases alike the retina, the epithelium of the lens and the lentil fibers showed no antibody reaction for CPAMD8 in the immunohistochemical staining. However, using Western blotting a faint band at the expected size of CPAMD8 was detectable in normal fetal and normal adult but not adult cataractous lenses (S1 Fig). 


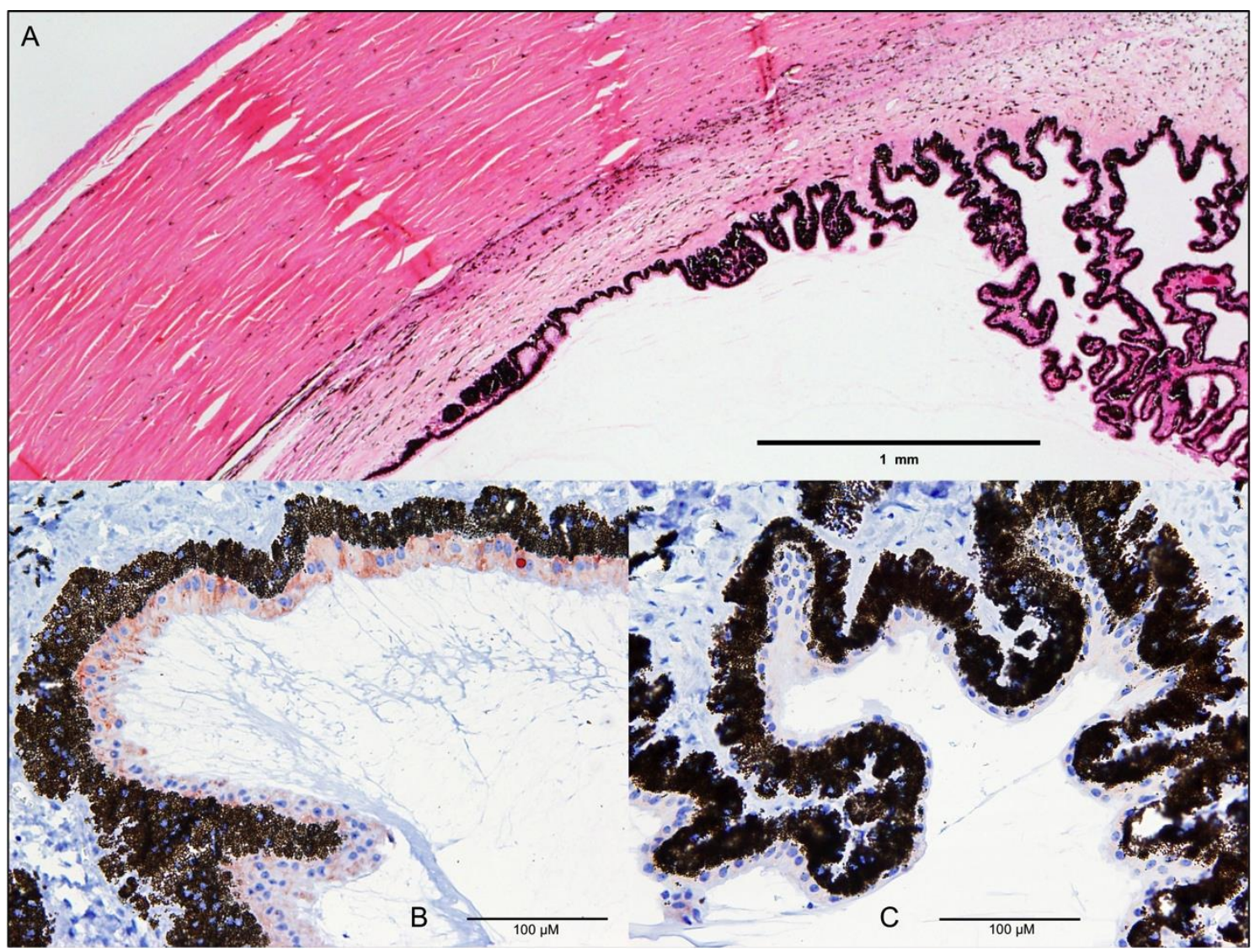

Fig 4. Loss of CPAMD8 expression in cataract cases.

Overview of cornea and ciliary body ( $A, H \& E$ staining). Physiologically, CPAMD8 is detectable by immunohistochemical staining in the epithelium of the ciliary body as cytoplasmic and vesicular staining in light brown (adult control sample) (B). In the cataract ciliary body epithelium, no CPAMD8 immunoreaction is detectable (C); CPAMD8 antibody; visualization by AEC.

\section{Discussion}

In the present study we identified a chain termination mutation (g.5995966C $>T$ ) in the first exon of CPAMD8 associated with congenital cataract formation in Red Holstein Friesian cattle. Information about the potential biological function of CPAMD8 is relatively scarce. Recently, Cheong et al. (2016) identified several mutations (missense, splice-site and frameshift variants) in CPAMD8 associated with ASD in humans, a disorder causing malformations of the anterior segment of the eye [15]. Affected patients showed several iridal malformations and cataracts, mainly of the posterior 
cortical type [15]. Observed bovine cataract cases with congenital mature cataracts did not show any other congenital anomalies of the iris or other ocular tissues. Likewise identified mutations in ASD patients and cataract cattle observed here differed regarding location and effects on the protein. Cheong et al. (2016) identified a homozygous missense mutation (c.4351T>C, p.S1451P) in exon 32 in one family affecting the conserved A2M domain of the CPAMD8 protein. In two other families two compound heterozygous mutations were identified respectively, causing aberrant premRNA splicing resulting in an in frame deletion/insertion or smaller transcripts. The identified mutation c.2352_2353insC in family 2 is predicted to cause a premature termination in exon 18 of 42 resulting in a truncated protein [15]. Here a missense mutation (g.5995966C $>\mathrm{T}$ ) in exon 1 of bovine CPAMD8 gene is reported leading to a premature termination that is predicted to cause a loss of protein in homozygous affected animals. In contrast, findings of Cheong et al. (2016) showed that a truncation of the protein by missense mutation, compound heterozygous frameshift mutations or aberrant pre-mRNA splicing are causing malformations of the anterior segment of the eye including cataracts.

Furthermore, we detected CPAMD8 in the ciliary body epithelium of healthy fetal and adult cattle, whereas no expression was detected in cataract cases. The non-pigmented part of the ciliary body secretes the aqueous humor by a complex process including steps of diffusion and ultrafiltration [24, 25]. Proteins in aqueous humor, although the concentration is rather low [25], are thought to derive from several sources like the plasma and the ciliary body itself $[26,27]$. Goel et al. (2013) identified 2,815 proteins in the ciliary body, 896 of which are unique to the tissue and cannot be found in the plasma [27]. Due to our observation of CPAMD8 in the non-pigmented epithelium of the ciliary body of healthy cattle, we assume that the CPAMD8 protein is usually secreted into the aqueous humor in the physiological state. This is supported by previous reports of CPAMD8 protein in human ciliary body [27] and aqueous humor [28-30]. To the best of our knowledge there have been no reports about defects of any other ciliary body proteins causing cataracts so far. CPAMD8 was not detectable by immunohistochemistry in lens tissues of fetal (approximately 11 weeks of age) and adult controls as well as cataract animals. However, the presumed absence of CPAMD8 in fetal and normal adult 
lenses was most likely only due to the reduced intensity of the immunohistochemical staining. Because, when using Western blotting as a more robust and quantitative method [31], a faint band at the expected size of CPAMD8 was also detectable in normal fetal and adult but not cataractous lenses (S1 Fig). So far there have been no reports of CPAMD8 in mammalian lens tissues, although it was detected in other ocular tissues and fluids e.g. aqueous humor [28-30], ciliary body [27], zonular fibres [32], vitreous humor [33], iris [34, 35], and choroid-retinal pigment epithelial complex [36].

We investigated CPAMD8 RNA expression in several bovine tissues including adult, fetal and cataractous lenses. Likewise, Cheong et al. (2016) reported an expression of CPAMD8 in human fetal lens in increasing levels from week 9 to 22 of gestation [15], at a time when the first lens fiber cells are already being formed (by the seventh week of gestation) [37]. Due to the similar pregnancy periods of humans and cattle, this clearly corresponds with our findings of CPAMD8 expression in bovine fetal lens tissue derived from a fetus of approximately 10 weeks of age according to the measured crown-rump length. Furthermore, CPAMD8 expression was detected in adult and cataractous lens material, indicating a postpartal expression of CPAMD8. Due to degradation in cataractous lenses RNA quantification was not possible.

Nevertheless, our findings of CPAMD8 RNA expression in lens tissues and CPAMD8 protein in ciliary body and lenses of healthy cattle are in accordance with previous reports $[15,27]$. In which way lens development might be influenced by the loss of CPAMD8 protein is a question that requires further investigation.

Concerning the structure of CPAMD8, the protein belongs to the C3/A2M family, which has a further six members, including A2M, PZP, CD109 and the complement components C3, C4, C5 [16]. The CPAMD8 gene has some structural similarities in common with other family members like, for example, A2M-associated domains and a Kazal-type serine protease inhibitor/follistatin-like domain, which is highly conserved across vertebrate species [16].

Functionally, members of the C3/A2M family are part of the innate immune system [17, 18]. Complement components recognize and eliminate pathogens, i.e. elimination is achieved by opsonization, lysis of pathogens and inflammatory response [18]. Alpha-2macroglobulin ( $\mathrm{A} 2 \mathrm{M})$ proteins are able to capture proteases of endogenous and 
Morgagnian cataract resulting from a naturally occurring nonsense mutation elucidates a role of CPAMD8 in mammalian lens development

exogenous origin and are evolutionarily highly conserved elements [17]. Ji et al. (2016) identified proteomic changes of the complement components $\mathrm{C} 3$ and $\mathrm{C} 5$ in aqueous humor of cataract patients and controls, being associated with cataract development. Seeking a potential role for CPAMD8 during cataract development, structurally similar A2M was identified acting as a carrier of specific growth factors, like as e.g. TGF $\beta$ [38]. TGF $\beta$ family members are present in ocular surroundings, i.e. lens $[39,40]$, aqueous and vitreous humor $[30,33,41]$. Changes in TGF $\beta$ levels are known to result in cataract development [42], indicating a strong regulation of the expression and bioavailability of TGF $\beta$. Also, TGF $\beta$ signaling is thought to have a key role during terminal fiber cell differentiation [43]. It has already been shown that $\mathrm{A} 2 \mathrm{M}$ in vitro, when present in ocular media, blocks cataractous changes induced by TGF $\beta$ [44], suggesting that suitable levels of molecules like $\mathrm{A} 2 \mathrm{M}$ in the ocular media have a protective function for lens cells against the damaging effects of TGF $\beta$. Here, reduced levels of $A 2 \mathrm{M}$ or similar molecules may predispose the lens to cataractogenesis. However, cataractous changes induced by TGF $\beta$ are usually similar to those found in anterior subcapsular cataracts [45]. ASD patients with mutations in CPAMD8 mainly suffer from cortical [15] and affected cattle from complete mature cataracts. These differences in cataract manifestation may indicate that CPAMD8 and $A 2 \mathrm{M}$, in terms of cataract prevention, act by different pathophysiological mechanisms, although they have structural similarities and have expression in aqueous humor and ciliary body in common.

Clinical examination of affected cattle in this study revealed a mature cataract at time of birth. With age, the cataract manifestation changed from mature to hypermature. Histological results, such as Morgagnian globules, liquefaction, the absence of lens epithelium and reduction of lens size, are typical for hypermature cataract progression of cortical cataracts [46]. Alterations leading to congenital, mature cataracts most likely affect a stage in embryonic lens development when lens fiber cells are already formed. Affected cattle seemed to have normal-sized lenses at the time of birth, which supports this hypothesis.

Besides the inherited form of cataractogenesis, intrauterine infections play a crucial role in cataract development. Bovine Viral Diarrhea-Mucosal Disease (BVD-MD) is known to be responsible for the development of cataracts in cattle [47]. Twenty-two of the 31 
sampled cataract cases were tested for BVD-MD by antigen-ELISA test with negative results. Therefore, an intrauterine infection as the cause of the cataracts could be excluded.

Our findings are not only interesting from a scientific point of view, they also have substantial relevance for practical breeding. Genotyping of male offspring of identified carriers revealed further heterozygous sires. Two of these tested heterozygous males were ranked top ten in the active, daughter-proven, artificially inseminated German Red Holstein population (ranked by relative breeding value) in August 2015 [48]. In summary, we have discovered a nonsense mutation ( $g .5995966 \mathrm{C}>\mathrm{T}, \mathrm{p} . \mathrm{G} \ln 74^{*}$ ) in the bovine CPAMD8 gene which coincides perfectly with cataract in the tested animals. We demonstrated that CPAMD8 is expressed in the ciliary body epithelium and lens of the unaffected eye and assume that a secretion of CPAMD8 from the epithelium into aqueous humor takes place under normal circumstances. The question of how in detail the loss of CPAMD8 in these cases results in cataract development needs to be examined in further studies. Nevertheless, our data provide convincing evidence that the absence of CPAMD8 leads to congenital cataract formation during embryonic development in Red Holstein Friesian cattle and are in accordance with previous findings that CPAMD8 is involved in eye development in humans [15].

\section{Materials and methods}

\section{Animal ethics/ethics statement}

The current study was performed in accordance with the ethical guidelines of the University of Goettingen and the German Animal Welfare act. Genotyping data and blood sampling had been done independent of the project in the frame of routine diagnostic parentage control and genomic selection programs of the German Holstein Friesian Association (DHV). The data sets were provided by DHV with written owner consent. Collection of blood samples within the breeding programs have been conducted exclusively by state-licensed veterinarians in accordance with the German Animal Welfare Act ( $\$ 6$ Abs. 1 Satz 2 TierSchG). Tissue samples and other native materials were obtained during or after regular slaughtering processes at an abattoir 
Morgagnian cataract resulting from a naturally occurring nonsense mutation elucidates a role of CPAMD8 in mammalian lens development

according to $\S 4$ of the German Animal Welfare Act. Therefore no formal ethical approval was required, since no other samples were collected for this study.

\section{Animal material and sample collection}

DNA samples from 31 affected (24 female, 7 male) Holstein Friesian cattle were available. Genomic DNA had been extracted from EDTA blood using a modified salting out procedure [49] or MagNa Pure LC DNA Isolation Kit I (Roche Diagnostics, Mannheim, Germany). DNA of related sires and other animals in the study was extracted from semen using a modified salting out method or obtained from the DNA depository of the Institute of Veterinary Medicine (Goettingen). Sample material for whole genome resequencing was extracted from EDTA blood as described above or semen using a phenol chloroform extraction method [50]. Lenses were obtained during regular slaughtering and stored at $-80^{\circ} \mathrm{C}$ or fixed in $10 \%$ neutral buffered formalin for histological analysis. Fetal lenses were prepared from fetus (approximately 79 (immunohistochemistry) and 69 (RNA analysis) days of age according to measured crown-rump length) of dam during regular slaughtering and handled as described above.

\section{Genome-wide association study (GWAS) and homozygosity mapping}

Genotyping was performed using the BovineSNP50 BeadChip (Illumina, San Diego, USA) according to the manufacturer's protocols. In total, 26 affected and 88 control HF cattle were genotyped. Final reports were generated using GenomeStudio V2011.1 (Illumina, San Diego, USA). Statistical analyses were performed using PLINK software [51]. Genotype data were filtered for quality control criteria as SNP call rate $>95 \%$ and minor allele frequency $\geq 5 \%$, reducing the final data set to 46,075 SNPs.

Firstly, a case-control association was calculated. P values were Bonferroni-adjusted to correct for multiple testing. Regions of extended homozygosity with shared alleles in cases were analyzed in a second step. Regions larger than $1 \mathrm{Mb}$ were included in the analysis. Genomic positions refer to assembly UMD_3.1. 
Morgagnian cataract resulting from a naturally occurring nonsense mutation elucidates a role of CPAMD8 in mammalian lens development

\section{Genome re-sequencing and variant calling}

Whole genome shotgun sequencing was conducted on five cattle: one affected animal (\#489) and its unaffected parents (\#870 and \#2104), one unaffected maternal grandmother (\#501) and an unaffected cross between the maternal grandmother (\#501) and the father of the affected cattle (\#870). Sequences were deposited with the European Nucleotide Archive (ENA) under accession number PRJEB20549 (http://www.ebi.uk/ena/data/view/PRJEB20549).

Sequencing libraries were prepared from 100ng DNA using the NEBNext Ultra DNA Library Prep Kit for Illumina (New England Biolabs, Ipswich, USA) according to the manufacturer's instructions. Paired-end sequencing was conducted on a NextSeq500 (Illumina, San Diego, USA).

An average of $85 \mathrm{M}$ (SD: $7.8 \mathrm{M}$ ) reads were generated per animal, of which $83 \%$ (SD: $1.3 \%$ ) were mapped to the bovine reference genome (UMD_3.1) resulting in a mean coverage of 7.8-fold (SD: 0.78$)$.

Sequences were mapped using a BWA software package [52]. Variants were named using GATK [53]. Effects on the amino acid sequence were predicted by the SNPeff tool [54].

\section{Genotyping by PCR using FRET technology}

SNP genotyping was done by fluorescence resonance energy transfer-PCR [55]. Primers were designed using NCBI primer-BLAST [56] with the following sequences: CPAMD8_FRET_93bp_F: GTTCTTGCTGCTGCTGCTG and CPAMD8_FRET_93bp_R: CAGCCAGCCTTCTCTCGC. Probes, bCPAMD8_probe: Cy5-GCGCTGAGCAGCCCCA-PHO and bCPAMD8_anchor: CGCCGCGGGACGGCG-Flc, were designed using the MeltCalc software $[57,58]$. Primers and probes were synthesized by Sigma-Aldrich (Taufkirchen, Germany).

PCR was performed on a LightCycler480 or LightCycler480 II (Roche Diagnostics, Mannheim, Germany) in a total volume of $25 \mu \mathrm{l}$ using FastStart Taq DNA Polymerase, dNTPack (Roche Diagnostics, Mannheim, Germany). One reaction mix included 1.5U Faststart Taq DNA Polymerase, $200 \mu \mathrm{M}$ dNTP, $10 \mu \mathrm{M}$ of each primer and probe, 1x GC$\mathrm{RICH}$ solution, 4.5mM MgCl 2 , 1x PCR reaction buffer (including $20 \mathrm{mM} \mathrm{MgCl}_{2}$ ), and 60- 
Morgagnian cataract resulting from a naturally occurring nonsense mutation elucidates a role of CPAMD8 in mammalian lens development

150ng of DNA. Cycling conditions were $95^{\circ} \mathrm{C}$ for $10 \mathrm{~min}$, followed by 35 to 40 cycles of $95^{\circ} \mathrm{C}$ for $10 \mathrm{sec}, 59^{\circ} \mathrm{C}$ for $20 \mathrm{sec}$ and $72^{\circ} \mathrm{C}$ for $10 \mathrm{sec}$. Final elongation step was $72^{\circ} \mathrm{C}$ for 5 min. Melting was done using an appropriate filter set and the following program: $95^{\circ} \mathrm{C}$ for $30 \mathrm{sec}, 45^{\circ} \mathrm{C}$ for $30 \mathrm{sec}, 75^{\circ} \mathrm{C}$ continuous acquisition mode $\left(2\right.$ to $3 /{ }^{\circ} \mathrm{C}$ ), ramp rate $0,29^{\circ} \mathrm{C} / \mathrm{sec}$, followed by $45^{\circ} \mathrm{C}$ for $30 \mathrm{sec}$.

\section{RNA extraction and cDNA product amplification}

RNA was extracted from 50 to $100 \mathrm{mg}$ tissue material homogenized in $900 \mu \mathrm{l}$ TRIzol ${ }^{\circledR}$ (Thermo Fisher Scientific) using Magna Lyzer Green Beads (Roche Diagnostics, Mannheim, Germany). After homogenization, RNeasy Plus Universal Kit (Qiagen, Hilden, Germany) was used following the manufacturer's protocol. RNA quality control was tested using Agilent RNA 6000 Pico Kit (Agilent Technologies, Waldbronn, Germany). cDNA synthesis was performed using Maxima H Minus First Strand cDNA Synthesis Kit, with dsDNase (Life Technologies). Oligo(dt) and Random Hexamer primers were used for reverse transcription.

\section{Digital droplet PCR assay for RNA expression analysis}

CPAMD8 RNA expression analyses were performed on a QX200Droplet Digital PCR system (Bio-Rad Laboratories, Munich, Germany) using RNA samples of one cataract case, one healthy adult and one fetal control. One technical replication was performed for every sample. Primers were designed using NCBI primer-BLAST [56]. Sequences of the primers were: CPAMD8_F: GATGGGAAGTCCGTCAGACC and CPAMD8_R: TGGACTCTCTCGTTGGGACA. As controls served ACTH and GAPDH with the following primer sequences: ACTB_cDNA_F: ACAGGATGCAGAAAGAGATCAATG, ACTB_cDNA_R: GTACTCCTGCTTGCTGATCCAC, GAPDH_cDNA_F: GTATGATTCCACCCACGGCA and GAPDH_cDNA_F: ACCACATACTCAGCACCAGC. All primers were synthesized by SigmaAldrich (Taufkirchen, Germany).

PCR mix at a total volume of $20 \mu \mathrm{l}$ included $10 \mu \mathrm{l}$ of $\mathrm{QX} 200^{\mathrm{TM}} \mathrm{ddPCR}^{\mathrm{TM}}$ EvaGreen Supermix (Bio-Rad Laboratories, Munich, Germany) and $2 \mu \mathrm{M}$ of each primer. $1 \mu \mathrm{l}$ to $2 \mu \mathrm{l}$ of diluted samples (CPAMD8 1:2, ACTH and GAPDH 1:250) were used in PCR. CDNA of cataract case was used without dilution $(2 \mu \mathrm{l})$. Droplets were generated using QX200 Droplet 
Morgagnian cataract resulting from a naturally occurring nonsense mutation elucidates a role of CPAMD8 in mammalian lens development

Generator (Bio-Rad Laboratories, Munich, Germany). PCR was performed in a thermocycler (Biometra, Göttingen, Germany) and cycling conditions were as follows: $95^{\circ} \mathrm{C}$ for $10 \mathrm{~min}$, followed by $45 \mathrm{cycles}$ of $95^{\circ} \mathrm{C}$ for $30 \mathrm{sec}$ and $60^{\circ} \mathrm{C}$ for $1 \mathrm{~min}$. Final droplet stabilization was performed at $98^{\circ} \mathrm{C}$ for $10 \mathrm{~min}$. Droplets were analyzed using the QX200 Droplet Reader (Bio-Rad Laboratories, Munich, Germany).

\section{Histology}

Tissues were fixed in $10 \%$ neutral buffered formalin for at least $48 \mathrm{~h}$, embedded in

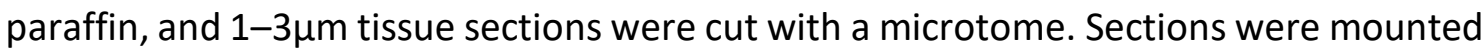
on glass slides, dried and stored for histological and immunohistochemical staining procedures. The morphological evaluation was performed on hematoxylin and eosin (H\&E) stained sections.

\section{Immunohistochemistry and Western blotting}

For protein analyses four commercially available antibodies were used (S2 Table). Specificity and sensitivity of the antibodies were tested using different bovine tissues and an in vitro expressed recombinant bovine CPAMD8 epitope (S1 Appendix, S2 Fig). Antibody concentrations were titrated until an optimal signal to noise ratio was obtained. For immunohistochemistry antibodies HPA031327 and HPA031328 were initially tested and HPA031328 gave best signals. Therefore, this antibody was used for the further studies. For immunohistochemistry paraffin-embedded tissue sections were deparaffinized and rinsed with TBS. For antigen epitope retrival, slides were heated in a microwave at 200W for $5 \times 3 \mathrm{~min}$ in TE-buffer (10mM Tris, 1mM ETDA, pH 9.0) and unspecific antibody binding was blocked with $3 \%$ hydrogenperoxide and $10 \%$ donkey serum in TBS-Triton (50mM Tris, $150 \mathrm{mM} \mathrm{NaCl}, 0.1 \%$ Triton X-100).

Immunoreaction was performed by incubation with the affinity purified polyclonal rabbit anti-CPAMD8 antibody (HPA031328, Sigma-Aldrich) (1:50, according to manufacturer's instructions) diluted in TBS-Triton followed by the secondary donkeyderived anti-rabbit antibody (RPN1004, GE Healthcare, Hamburg, Germany) (1:100) for $2 \mathrm{~h}$ and $1 \mathrm{~h}$, respectively. After each step, slides were rinsed thoroughly with TBS-Triton. The immunoreaction was visualized using Avidin-conjugated peroxidase as enhancer 
and AEC (3-Amino-9-ethylcarbazole) as chromogen. Sections were lightly counterstained with hematoxylin.

For Western blotting proteins were lysed using lysis buffer containing 50mM Tris, $150 \mathrm{mM} \mathrm{NaCl}$, 1mM EDTA, 1mM EGTA, 5\% glycerol, 1\% Triton X-100, 0.1\% DTT and EDTA free protease inhibitor cocktail (Roche Diagnostics, Mannheim, Germany). Homogenization of samples was done using DIAX900 Homogenizer (Heidolph, Schwabach, Germany) or MagNA Lyser Green Beads (Roche Diagnostics, Mannheim, Germany) followed by an incubation for 1 hour and centrifugation for $10 \mathrm{~min}$ at $500 \mathrm{~g}$ and $4^{\circ} \mathrm{C}$. Proteins were quantified by Bradford method.

$60 \mu \mathrm{g}$ of proteins were analyzed using SDS-Page (4-12\% Bis Tris-Plus gels or $8 \%$ Bis Tris Plus gels, Life Technologies). As positive controls human CPAMD8 over-expression Lysate (OriGene Technologies, Rockville, USA) and $5 \mu$ l of in vitro produced bovine CPAMD8 were used. Proteins were transferred to nitrocellulose membrane using semidry blotter (Brenzel Bioanalytik, Lahntal, Germany). After transfer membranes were blocked with $5 \%$ non-fat dry milk in TBS-T for $2 \mathrm{~h}$, followed by incubation with antiCPAMD8 antibody (S2 Table, dilution 1:200) for $1 \mathrm{~h}$ at room temperature. Secondary goat anti-rabbit IgG $(\mathrm{H}+\mathrm{L})$-HRP conjugate antibody (Bio-Rad Laboratories, Munich, Germany) was diluted 1:5000 and also incubated for $1 \mathrm{~h}$ at room temperature. Detection of chemiluminescent signals was performed using Amersham ECL detection reagent (GE Healthcare, Hamburg, Germany) and membranes were exposed to X-ray films (GE Healthcare, Hamburg, Germany).

\section{Acknowledgment}

The authors thank S. Pach, R. Andag, M. Scharfenstein, S. Loos, L. Jüttner, S. Bierau, S. Balzer and K. Brekerbohm for their excellent technical assistance. We are grateful to T. Leeb who kindly validated our initial PLINK-data. J. Hartmann (Rinder-Union West eG) is thanked for providing samples and data. Thanks to $\mathrm{H}$. Melbaum for providing semen samples. F. Reinhardt (VIT) and D. Segelke (VIT) are thanked for providing pedigree data, and thanks go to G. von Gadow for providing pictures of cases. 


\section{References}

1. Pascolini D, Mariotti SP. Global estimates of visual impairment: $2010 . \mathrm{Br} \mathrm{J}$ Ophthalmol. 2012; 96(5):614-8. Epub 2011/12/03. https://doi.org/10.1136/ bjophthalmol-2011-300539. PMID: 22133988.

2. Shiels A, Mackay D, Bennett T. Cat-Map [updated 2014/01/10; cited 2016 2016/12/01]. Available from: http://cat-map.wustl.edu.

3. Hejtmancik JF. Congenital cataracts and their molecular genetics. Seminars in cell \& developmental biology. 2008; 19(2):134-49. Epub 2007/11/24. https://doi.org/10.1016/j.semcdb.2007.10.003. PMID: 18035564; PubMed Central PMCID: PMC2288487.

4. Krump L, O'Grady L, Lorenz I, Grimes T. Congenital cataracts in an Ayrshire herd: a herd case report. Irish veterinary journal. 2014; 67(1):2. Epub 2014/01/28. https://doi.org/10.1186/2046-0481-67-2. PMID: 24460638; PubMed Central PMCID: PMC3905159.

5. Detlefson JA, Yapp WW. The Inheritance of Congenital Cataract in Cattle. The American Naturalist. 1920; 54(632):277-80. https://doi.org/10.2307/2455981.

6. Carter $\mathrm{AH}$. An inherited blindness (cataract) in cattle. Proceedings of the New Zealand Society of Animal Production. 1960; 20:108.

7. Ashton Barnett KC, Clay CE Clegg FG. Congenital nuclear cataracts in cattle. Vet Rec. 1977; 100(24):505-8. Epub 1977/06/11. PMID: 878267.

8. Hurley S. Blind but healthy calves. Vet Rec. 2008; 163(19):579. PMID: 18997190.

9. Gregory PW, Mead SW, Regan WM. A congenital hereditary eye defect of cattle. The Journal of Heredity. 1943; 34:125-8.

10. Saunders LZ, Fincher MG. Hereditary multiple eye defects in grade Jersey calves. Cornell Vet. 1951; 41(4):351-66. Epub 1951/10/01. PMID: 14887336.

11. Gelatt KN. Cataracts in cattle. Journal of the American Veterinary Medical Association. 1971; 159(2):195-200. Epub 1971/07/15. PMID: 5106050.

12. Murgiano L, Jagannathan V, Calderoni V, Joechler M, Gentile A, Drogemuller C. Looking the cow in the eye: deletion in the NID1 gene is associated with recessive inherited cataract in Romagnola cattle. PLoS One. 2014; 9(10): e110628. Epub 2014/10/28. https://doi.org/10.1371/journal.pone.0110628. PMID: 25347398; PubMed Central PMCID: PMC4210201.

13. Graw J. Genetics of crystallins: cataract and beyond. Exp Eye Res. 2009; 88(2):173-89. https://doi.org/10.1016/j.exer.2008.10.011. PMID: 19007775. 
14. Graw J. The genetic and molecular basis of congenital eye defects. Nature reviews Genetics. 2003; 4(11):876-88. Epub 2003/11/25. https://doi.org/ 10.1038/nrg1202. PMID: 14634635.

15. Cheong SS, Hentschel L, Davidson AE, Gerrelli D, Davie R, Rizzo R, et al. Mutations in CPAMD8 Cause a Unique Form of Autosomal-Recessive Anterior Segment Dysgenesis. Am J Hum Genet. 2016; 99:1338-1352. https://doi.org/ 10.1016/j.ajhg.2016.09.022. PMID: 27839872.

16. Li ZF, Wu XH, Engvall E. Identification and characterization of CPAMD8, a novel member of the complement 3/alpha2-macroglobulin family with a C-terminal Kazal domain. Genomics. 2004; 83(6):1083-93. Epub 2004/06/05. https://doi.org/10.1016/j.ygeno.2003.12.005. PMID: 15177561.

17. Armstrong PB, Quigley JP. Alpha2-macroglobulin: an evolutionarily conserved arm of the innate immune system. Dev Comp Immunol. 1999; 23(4-5):375-90. PMID: 10426429.

18. Dunkelberger JR, Song WC. Complement and its role in innate and adaptive immune responses. Cell Res. 2010; 20(1):34-50. https://doi.org/ 10.1038/cr.2009.139. PMID: 20010915.

19. Kenny EE, Pe'er I, Karban A, Ozelius L, Mitchell AA, Ng SM, et al. A genome-wide scan of Ashkenazi Jewish Crohn's disease suggests novel susceptibility loci. PLoS Genet. 2012; 8(3): e1002559. Epub 2012/03/14. https://doi.org/ 10.1371/journal.pgen.1002559. PMID: 22412388; PubMed Central PMCID: PMC3297573.

20. Baranzini SE, Wang J, Gibson RA, Galwey N, Naegelin Y, Barkhof F, et al. Genomewide association analysis of susceptibility and clinical phenotype in multiple sclerosis. Hum Mol Genet. 2009; 18(4):767-78. Epub 2008/11/18. https://doi.org/10.1093/hmg/ddn388. PMID: 19010793; PubMed Central PMCID: PMC4334814.

21. Sousounis K, Athippozhy AT, Voss SR, Tsonis PA. Plasticity for axolotl lens regeneration is associated with age-related changes in gene expression. Regeneration (Oxf). 2014; 1(3):47-57. https://doi.org/10.1002/reg2.25. PMID: 27499863 ; PubMed Central PMCID: PMCPMC4895297.

22. Garbe JR, Da Y. Pedigraph: A Software Tool for the Graphing and Analysis of Large Complex Pedigree. User manual Version 2.4. Department of Animal Science, University of Minnesota. 2008.

23. Barrett JC, Fry B, Maller J, Daly MJ. Haploview: analysis and visualization of LD and haplotype maps. Bioinformatics. 2005; 21(2):263-5. Epub 2004/08/07. https://doi.org/10.1093/bioinformatics/bth457. PMID: 15297300. 
24. Brubaker RF. Flow of aqueous humor in humans [The Friedenwald Lecture]. Invest Ophthalmol Vis Sci. 1991; 32(13):3145-66. PMID: 1748546.

25. To $\mathrm{CH}$, Kong $\mathrm{CW}$, Chan $\mathrm{CY}$, Shahidullah $\mathrm{M}$, Do CW. The mechanism of aqueous humour formation. Clin Exp Optom. 2002; 85(6):335-49. PMID: 12452784.

26. Freddo TF, Bartels SP, Barsotti MF, Kamm RD. The source of proteins in the aqueous humor of the normal rabbit. Invest Ophthalmol Vis Sci. 1990; 31(1):12537. PMID: 2298533.

27. Goel R, Murthy KR, Srikanth SM, Pinto SM, Bhattacharjee M, Kelkar DS, et al. Characterizing the normal proteome of human ciliary body. Clin Proteomics. 2013; 10(1):9. https://doi.org/10.1186/1559-0275-10-9. PMID: 23914977; PubMed Central PMCID: PMCPMC3750387.

28. Bennett KL, Funk M, Tschernutter M, Breitwieser FP, Planyavsky M, Ubaida Mohien $\mathrm{C}$, et al. Proteomic analysis of human cataract aqueous humour: Comparison of one-dimensional gel LCMS with two-dimensional LCMS of unlabelled and iTRAQ(R)-labelled specimens. J Proteomics. 2011; 74(2):151-66. https://doi.org/10.1016/j.jprot.2010.10.002. PMID: 20940065.

29. Ji Y, Rong X, Ye H, Zhang K, Lu Y. Proteomic analysis of aqueous humor proteins associated with cataract development. Clin Biochem. 2015; 48(18):1304-9. https://doi.org/10.1016/j.clinbiochem.2015.08.006. PMID: 26265347.

30. Murthy KR, Rajagopalan P, Pinto SM, Advani J, Murthy PR, Goel R, et al. Proteomics of human aqueous humor. OMICS. 2015; 19(5):283-93. https://doi.org/10.1089/omi.2015.0029. PMID: 25933257.

31. Kurien BT, Dorri Y, Dillon S, Dsouza A, Scofield RH. An overview of Western blotting for determining antibody specificities for immunohistochemistry. Methods Mol Biol. 2011; 717:55-67. https://doi.org/10.1007/978-1-61779-0249_3. PMID: 21370024.

32. De Maria A, Wilmarth PA, David LL, Bassnett S. Proteomic Analysis of the Bovine and Human Ciliary Zonule. Invest Ophthalmol Vis Sci. 2017; 58(1):573-85. https://doi.org/10.1167/iovs.16-20866. PMID: 28125844; PubMed Central PMCID: PMCPMC5283081.

33. Murthy KR, Goel R, Subbannayya Y, Jacob HK, Murthy PR, Manda SS, et al. Proteomic analysis of human vitreous humor. Clin Proteomics. 2014; 11(1):29. https://doi.org/10.1186/1559-0275-11-29. PMID: 25097467; PubMed Central PMCID: PMCPMC4106660. 
34. Murthy KR, Dammalli M, Pinto SM, Murthy KB, Nirujogi RS, Madugundu AK, et al. A Comprehensive Proteomics Analysis of the Human Iris Tissue: Ready to Embrace Postgenomics Precision Medicine in Ophthalmology? OMICS. 2016; 20(9):510-9. https://doi.org/10.1089/omi.2016.0100. PMID: 27631190.

35. Zhang $P$, Kirby D, Dufresne $C$, Chen $Y$, Turner R, Ferri $S$, et al. Defining the proteome of human iris, ciliary body, retinal pigment epithelium, and choroid. Proteomics. 2016; 16(7):1146-53. https://doi.org/10.1002/pmic.201500188. PMID: 26834087; PubMed Central PMCID: PMCPMC4833206.

36. Skeie JM, Mahajan VB. Proteomic landscape of the human choroid-retinal pigment epithelial complex. JAMA Ophthalmol. 2014; 132(11):1271-81. https://doi.org/10.1001/jamaophthalmol.2014.2065. PMID: 25058583.

37. Duckman RH. Visual Development, Diagnosis, and Treatment of the Pediatric Patient: Lippincott Williams \& Wilkins; 2006.

38. Crookston KP, Webb DJ, Wolf BB, Gonias SL. Classification of alpha 2macroglobulin-cytokine interactions based on affinity of noncovalent association in solution under apparent equilibrium conditions. J Biol Chem. 1994; 269(2):1533-40. PMID: 7507109.

39. Pelton RW, Saxena B, Jones M, Moses HL, Gold LI. Immunohistochemical localization of TGF beta 1, TGF beta 2, and TGF beta 3 in the mouse embryo: expression patterns suggest multiple roles during embryonic development. J Cell Biol. 1991; 115(4):1091-105. PMID: 1955457; PubMed Central PMCID: PMCPMC2289937.

40. Potts JD, Bassnett S, Beebe DC. Expression of transforming growth factor beta in the embryonic avian lens coincides with the presence of mitochondria. Dev Dyn. 1995; 203(3):317-23. https://doi.org/10.1002/aja.1002030304. PMID: 8589429.

41. Chowdhury UR, Madden BJ, Charlesworth MC, Fautsch MP. Proteome analysis of human aqueous humor. Invest Ophthalmol Vis Sci. 2010; 51(10):4921-31. https://doi.org/10.1167/iovs.10-5531. PMID: 20463327; PubMed Central PMCID: PMCPMC3066620.

42. de longh RU, Gordon-Thomson C, Chamberlain CG, Hales AM, McAvoy JW. Tgfbeta receptor expression in lens: implications for differentiation and cataractogenesis. Exp Eye Res. 2001; 72(6):649-59. https://doi.org/ 10.1006/exer.2001.1001. PMID: 11384153.

43. de longh RU, Lovicu FJ, Overbeek PA, Schneider MD, Joya J, Hardeman ED, et al. Requirement for TGFbeta receptor signaling during terminal lens fiber differentiation. Development. 2001; 128(20):3995-4010. PMID: 11641223. 
44. Schulz MW, Chamberlain CG, McAvoy JW. Inhibition of transforming growth factor-beta-induced cataractous changes in lens explants by ocular media and alpha 2-macroglobulin. Invest Ophthalmol Vis Sci. 1996; 37(8):1509-19. PMID: 8675393.

45. Lovicu FJ, Schulz MW, Hales AM, Vincent LN, Overbeek PA, Chamberlain CG, et al. TGFbeta induces morphological and molecular changes similar to human anterior subcapsular cataract. $\mathrm{Br} J$ Ophthalmol. 2002; 86(2):220-6. Epub 2002/01/30. PMID: 11815351; PubMed Central PMCID: PMCPmc1771017.

46. Cogan DG. Anatomy of lens and pathology of cataracts. Exp Eye Res. 1962; 1:2915. PMID: 14021964.

47. Bistner SI, Rubin LF, Saunders LZ. The Ocular Lesions of Bovine Viral DiarrheaMucosal Disease. Path Vet. 1970; 7:275-86.

48. VIT, w.V. VIT. Relative Breeding Value (ranked by RZG), daughter proven, only active Al bulls, German Red Holsteins 2015 [2015/10/01]. Available from: http://www.vit.de/fileadmin/user_upload/vit-fuersrind/zuchtwertschaetzung/ milchrinder-zws-online/RotBunt_RZG_aktiveBullen.pdf.

49. Miller SA, Dykes DD, Polesky HF. A simple salting out procedure for extracting DNA from human nucleated cells. Nucleic Acids Res. 1988; 16(3):1215. Epub 1988/02/11. PMID: 3344216; PubMed Central PMCID: PMC334765.

50. Chomczynski $P$, Sacchi N. Single-step method of RNA isolation by acid guanidinium thiocyanate-phenol-chloroform extraction. Anal Biochem. 1987; 162(1):156-9. https://doi.org/10.1006/abio.1987.9999. PMID: 2440339.

51. Purcell S, Neale B, Todd-Brown K, Thomas L, Ferreira MA, Bender D, et al. PLINK: a tool set for whole-genome association and population-based linkage analyses. Am J Hum Genet. 2007; 81(3):559-75. Epub 2007/08/19. https://doi.org/10.1086/519795. PMID: 17701901; PubMed Central PMCID: PMCPmc1950838.

52. Li H, Durbin R. Fast and accurate short read alignment with Burrows-Wheeler transform. Bioinformatics. 2009; 25(14):1754-60. https://doi.org/10.1093 /bioinformatics/btp324. PMID: 19451168; PubMed Central PMCID: PMCPMC2705234.

53. McKenna A, Hanna M, Banks E, Sivachenko A, Cibulskis K, Kernytsky A, et al. The Genome Analysis Toolkit: a MapReduce framework for analyzing next-generation DNA sequencing data. Genome Res. 2010; 20(9):1297-303. https://doi.org/10.1101/gr.107524.110. PMID: 20644199; PubMed Central PMCID: PMCPMC2928508. 
54. Cingolani $P$, Platts $A$, Wang le $L$, Coon $M$, Nguyen $T$, Wang $L$, et al. A program for annotating and predicting the effects of single nucleotide polymorphisms, SnpEff: SNPs in the genome of Drosophila melanogaster strain w1118; iso-2; iso3. Fly (Austin). 2012; 6(2):80-92. https://doi.org/10.4161/fly.19695. PMID: 22728672 ; PubMed Central PMCID: PMCPMC3679285.

55. Förster T. Zwischenmolekulare Energiewanderung und Fluoreszenz. Annalen der Physik. 1948; 437(1-2):55-75. https://doi.org/10.1002/andp.19484370105.

56. Ye J, Coulouris G, Zaretskaya I, Cutcutache I, Rozen S, Madden TL. Primer-BLAST: a tool to design target-specific primers for polymerase chain reaction. BMC Bioinformatics. 2012; 13:134. Epub 2012/06/20. https://doi.org/10.1186/14712105-13-134. PMID: 22708584; PubMed Central PMCID: PMC3412702.

57. Schutz E, von Ahsen N. Spreadsheet software for thermodynamic melting point prediction of oligonucleotide hybridization with and without mismatches. BioTechniques. 1999; 27(6):1218-22, 24. Epub 2000/01/13. PMID: 10631501.

58. von Ahsen N, Oellerich M, Armstrong VW, Schutz E. Application of a thermodynamic nearest-neighbor model to estimate nucleic acid stability and optimize probe design: prediction of melting points of multiple mutations of apolipoprotein B-3500 and factor $\mathrm{V}$ with a hybridization probe genotyping assay on the LightCycler. Clinical chemistry. 1999; 45(12):2094-101. Epub 1999/12/10. PMID: 10585340. 


\section{Supporting information}

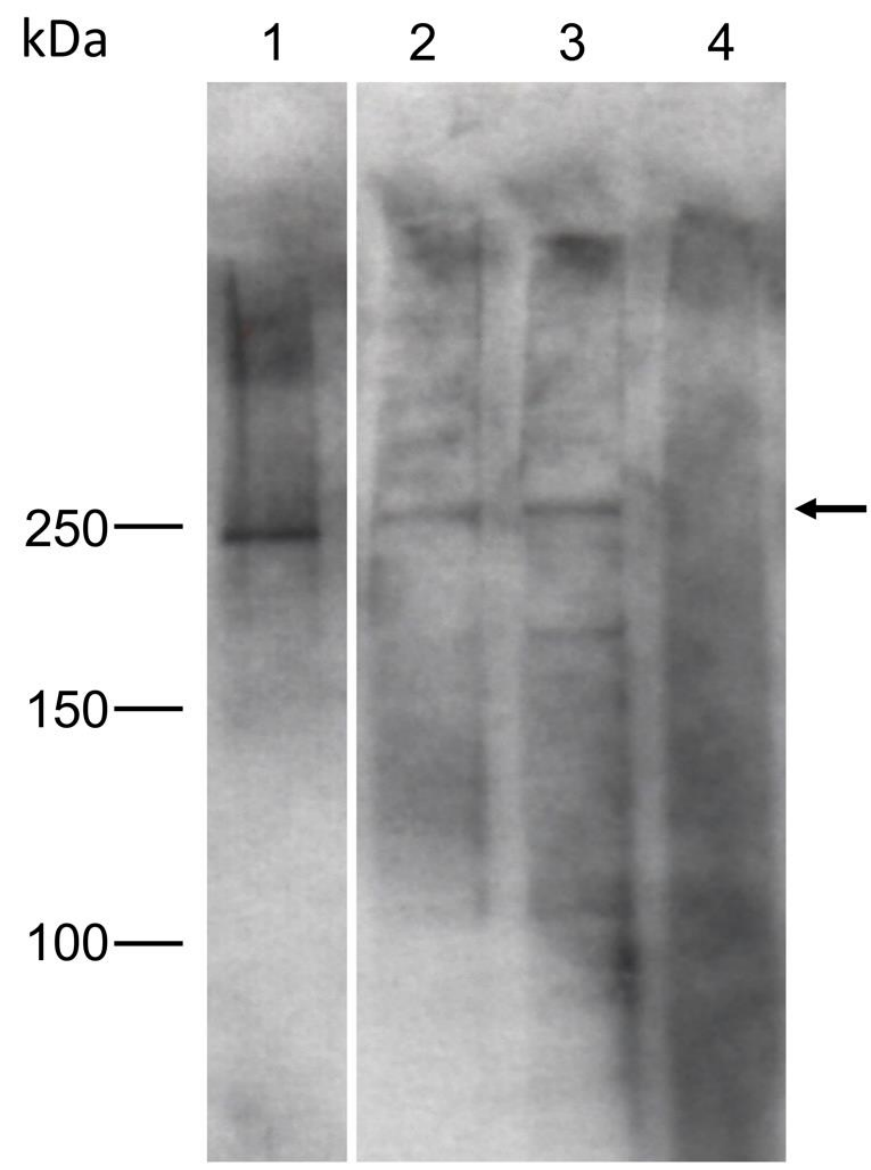

S1 Fig. Western blot analysis of normal adult, normal fetal and adult cataractous lenses.

Protein extracts of a normal adult lens (lane 2), normal fetal lens (lane 3) and adult cataractous lens (lane 4) were loaded on a 4-12\% gradient SDS-PAGE. As positive control human CPAMD8 over-expression lysate was used (lane 1). Proteins were transferred to nitrocellulose membranes and filters were blocked with $5 \%$ non-fat dry milk in TBS-T followed by incubation with anti-CPAMD8 antibody HPA031328 (S2 Table, dilution 1:200). Detection of chemiluminescent signals was performed using Amersham ECL detection reagent and membranes were exposed to X-ray films. CPAMD8 bands in lane 1 (human control lysate), 2 (bovine normal adult lens) and 3 (bovine normal fetal lens) are indicated with an arrow. Protein sizes are indicated in kDa. Scans of X-ray films were cropped using GIMP 2.8.18 (GNU Image Manipulation Program). 


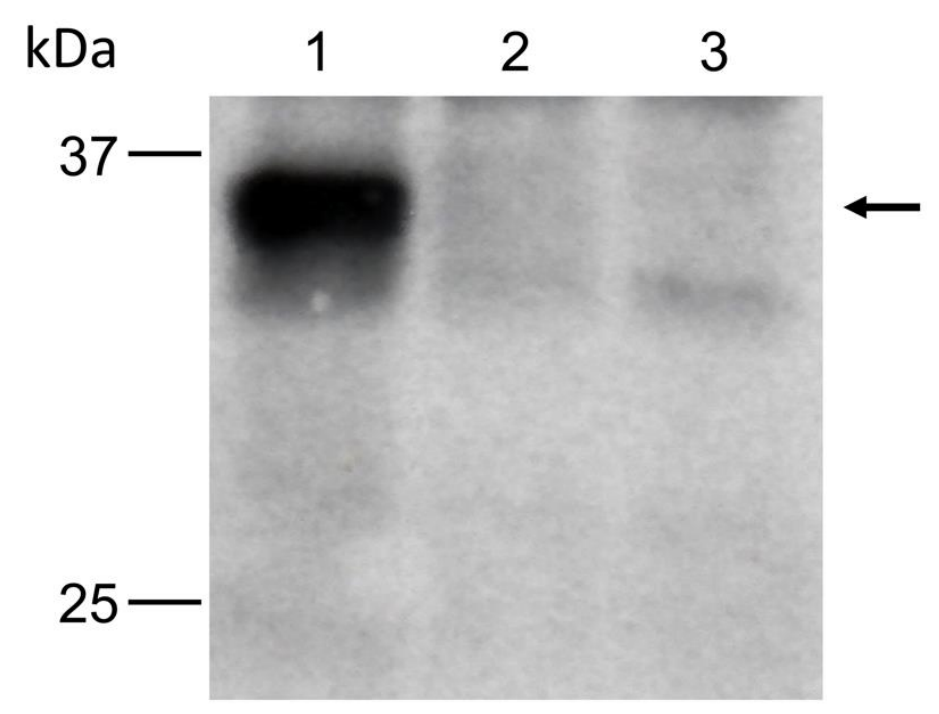

S2 Fig. Analysis of antibody specificity and sensitivity using an in vitro expressed bovine CPAMD8 epitope and CPAMD8 antibody HPA031328.

Five $\mu \mathrm{l}$ of in vitro produced bovine CPAMD8 epitopes were loaded on a 4-12\% gradient SDS-PAGE (lane 1, lane 2). Proteins were transferred to nitrocellulose membranes and filters were blocked with $5 \%$ non-fat dry milk in TBS-T followed by incubation with antiCPAMD8 antibody HPA031328 (S2 Table, dilution 1:200). Detection of chemiluminescent signals was performed using Amersham ECL detection reagent and membranes were exposed to X-ray films. The band in lane 1 shows the expected size of the epitope (approx. $33 \mathrm{kDa}$ ) and is indicated with an arrow. In lane 2 another in vitro expressed epitope lysate was loaded showing no reactivity. Lane 3 shows a negative control lysate. Protein sizes are indicated in $\mathrm{kDa}$. Scans of X-ray films were cropped using GIMP 2.8.18 (GNU Image Manipulation Program). 


\section{S1 Table. Summary of the clinical findings of cataract cases.}

Consciousness, posture, gait, swallowing and tongue tone were normal in all cases. Behavior differed from calm alertness to anxiety. If not stated otherwise the ocular fundus was without pathological findings.

\begin{tabular}{|c|c|c|c|}
\hline \multirow{2}{*}{$\begin{array}{l}\text { Cattle } \\
\text { no. }\end{array}$} & \multirow{2}{*}{$\begin{array}{l}\text { Age in } \\
\text { months }\end{array}$} & \multicolumn{2}{|l|}{ Clinical findings } \\
\hline & & Left eye & Right eye \\
\hline 224 & 13 & $\begin{array}{ll}\text { - } & \text { partial blindness } \\
\text { - } & \text { inducible nystagmus } \\
\text { - } & \text { mydriasis } \\
\text { - } & \text { cataract } \\
\text { - } & \text { microphakia } \\
\text { - } & \text { irregular shaped lens } \\
\text { - } & \text { posterior synechia }\end{array}$ & $\begin{array}{l}\text { - } \text { complete blindness } \\
\text { - } \text { no palpebral reflex } \\
\text { - } \text { mydriasis } \\
\text { - } \text { cataractous lens } \\
\text { disconnected from iris } \\
\text { and ventrally subsided } \\
\text { - glaucoma } \\
\text { - uveitis } \\
\text { - } \text { retinitis } \\
\text { - } \text { exophthalmos }\end{array}$ \\
\hline 227 & 13 & $\begin{array}{ll}\text { - } & \text { partial blindness } \\
\text { - } & \text { low-grade ventral } \\
& \text { strabismus } \\
\text { - } & \text { palpebral reflex slightly } \\
& \text { reduced } \\
\text { - } & \text { sensibility around the eye } \\
\text { slightly reduced } \\
\text { - } \text { mydriasis } \\
\text { - } \text { cataract } \\
\text { - } \text { mikrophakia } \\
\text { - irregular shaped lens } \\
\text { continuing into the anterior } \\
\text { - } \text { chamber } \\
\text { posterior synechia }\end{array}$ & $\begin{array}{l}\text { - } \text { partial blindness } \\
\text { - } \text { mydriasis } \\
\text { - } \text { cataract } \\
\text { - mikrophakia }\end{array}$ \\
\hline 489 & 31.5 & $\begin{array}{l}\text { - } \text { partial blindness } \\
\text { - } \text { mydriasis } \\
\text { - } \text { cataract } \\
\text { - mikrophakia }\end{array}$ & $\begin{array}{ll}\text { - } & \text { partial blindness } \\
\text { - } & \text { mydriasis } \\
\text { - } & \text { cataract } \\
\text { - } & \text { mikrophakia } \\
\text { - } & \text { exophthalmus } \\
\end{array}$ \\
\hline 908 & 30 & $\begin{array}{ll}\text { - } & \text { partial blindness } \\
\text { - } & \text { mydriasis } \\
\text { - } & \text { cataract } \\
\text { - } & \text { irregular shaped lens with } \\
\text { attached fibrils continuing } \\
\text { into posterior chamber } \\
\text { - } \text { mikrophakia } \\
\text { - cloudy and filamentous } \\
\text { content in posterior } \\
\text { chamber }\end{array}$ & $\begin{array}{ll}\text { - } & \text { partial blindness } \\
\text { - } & \text { mydriasis } \\
\text { - } & \text { cataract } \\
\text { - } & \text { mikrophakia } \\
\text { - } & \text { irregular shaped lens } \\
& \text { located lateral } \\
& \text { continuing into } \\
& \text { anterior chamber }\end{array}$ \\
\hline
\end{tabular}


Morgagnian cataract resulting from a naturally occurring nonsense mutation elucidates a role of CPAMD8 in mammalian lens development

S2 Table. Anti-CPAMD8 antibodies used for Western blotting and immunohistochemistry.

\begin{tabular}{|c|c|c|c|c|c|}
\hline $\begin{array}{l}\text { Anti- } \\
\text { CPAMD8 } \\
\text { antibody }\end{array}$ & $\begin{array}{l}\text { Recombinant } \\
\text { protein epitope } \\
\text { signature tag } \\
\text { (PrEST) antigen } \\
\text { sequence }\end{array}$ & $\begin{array}{l}\text { Verified } \\
\text { species } \\
\text { reactivity }\end{array}$ & Host & Clonality & $\begin{array}{l}\text { Antigen } \\
\text { sequence } \\
\text { identity to } \\
\text { bovine } \\
\text { CPAMD8 } \\
\text { ortholog }\end{array}$ \\
\hline HPA0313301) & $\begin{array}{l}\text { SDLGLNNITAKALA } \\
\text { YGDTNCCRDGRSS } \\
\text { KHPEENHADRRVP } \\
\text { IGVDHVRRSVMVE } \\
\text { AEGVPRAYTYSAF } \\
\text { FCPSERVHISTPNK } \\
\text { YEFQYVQR } \\
\end{array}$ & Human & Rabbit & polyclonal & $82 \%$ \\
\hline HPA0313271) & $\begin{array}{l}\text { YLPSYLSLGSWYSP } \\
\text { SQCYLQLQPPSHP } \\
\text { LQVGEEAYFSVKST } \\
\text { CPCNFTLYYEVAA } \\
\text { RGNIVLSG }\end{array}$ & Human & Rabbit & polyclonal & $95.16 \%$ \\
\hline HPA0313281) & $\begin{array}{l}\text { FPETWIWHCLNIS } \\
\text { DPSGEGTLSVKVP } \\
\text { DSITSWVGEAVAL } \\
\text { STSQGLGIAEPSLL } \\
\text { KTFKPFFVDFMLP } \\
\text { ALIIRGEQVKIPLSV } \\
\text { YNYMGTCAEVYM } \\
\text { KLSVPK }\end{array}$ & Human & Rabbit & polyclonal & $81.82 \%$ \\
\hline orb182705 & unknown & $\begin{array}{l}\text { Human, } \\
\text { cow, dog }\end{array}$ & Rabbit & polyclonal & unknown \\
\hline
\end{tabular}

1) Sigma-Aldrich Chemie, (Taufkirchen, Germany)

2) OriGene Technologies (Rockville, USA) 
Morgagnian cataract resulting from a naturally occurring nonsense mutation elucidates a role of CPAMD8 in mammalian lens development

S1 Appendix. Materials and methods used for in vitro expression of a bovine CPAMD8 epitope.

\section{In vitro production of bovine recombinant CPAMD8 epitope}

Template amplification was done using FastStart Taq DNA Polymerase, dNTPack (Roche Diagnostics, Mannheim, Germany) with following mixture: $2 U$ of FastStart Taq DNA Polymerase, $200 \mu \mathrm{M}$ of each dNTP, $2 \mathrm{mM} \mathrm{MgCl} 2$ and $10 \mu \mathrm{M}$ of following primers 150608_Epitop_AK4_AK1_2_F: ATGACGGACCTGGTGAGC and 150608_Epitop_AK4_ AK1_2_R: CAATCATGCCCGCTGTGTC. Primers were again designed with NCBI primerBLAST and synthesized by Sigma-Aldrich (Taufkirchen, Germany). $0.4 \mu \mathrm{l}$ cDNA of $1 \mu \mathrm{g}$ reverse transcription from kidney sample of healthy control was used as template. Cycling conditions were set to $95^{\circ} \mathrm{C}$ for $10 \mathrm{~min}$, followed by 40 cycles of $95^{\circ} \mathrm{C}$ for $30 \mathrm{sec}$, $63^{\circ} \mathrm{C}$ for $30 \mathrm{sec}$ and $72^{\circ} \mathrm{C}$ for $60 \mathrm{sec}$ and a final elongation for $5 \mathrm{~min}$ at $72^{\circ} \mathrm{C}$.

Production of linear expression template was done using RTS 100 E. coli LinTempGen Set, His-tag kit (Biotechrabbit, Hennigsdorf, Germany). Overlap regions were added during PCR. The PCR reaction mix at a total volume of $50 \mu$ included $3 U$ Phusion ${ }^{\circledR}$ HighFidelity DNA Polymerase (Finnzymes, ThermoFisher Scientific, Germany), 250 $\mu$ M dNTP, 250nM of the following gene-specific C-terminal His 6 -tag primers: CPAMD8Epifor: CTTTAAGAAGGAGATATACCATGACGGACCTGGTGAGC and CPAMD8EpiHisrev: TGATGATGAGAACCCCCCCCAATCTAGCCCGCTGTGTC, and $7.5 \mathrm{mM} \mathrm{MgCl}_{2}$. Cycling conditions were $94^{\circ} \mathrm{C}$ for $4 \mathrm{~min}$, followed by $94^{\circ} \mathrm{C}$ for $1 \mathrm{~min}, 63^{\circ} \mathrm{C}$ for $1 \mathrm{~min}$ and $72^{\circ} \mathrm{C}$ for $1 \mathrm{~min}$ for 20 cycles. Final extension was performed at $42^{\circ} \mathrm{C}$ for $5 \mathrm{~min}$.

PCR amplification control was performed on a 1.5\% agarose gel with ethidium bromide. Regulatory elements and His 6 -tag were added during second PCR step using identical PCR reaction mix as described above and extra T7 Promoter Primer (480nM), T7 Terminator Primer (480nM), C-terminal His ${ }_{6}$-tag DNA (1x) and $4 \mu \mathrm{l}$ of first PCR product as template. Cycling conditions were $94^{\circ} \mathrm{C}$ for $4 \mathrm{~min}, 25$ cycles of $94^{\circ} \mathrm{C}$ for $1 \mathrm{~min}, 63^{\circ} \mathrm{C}$ for 1 $\min$ and $72^{\circ} \mathrm{C}$ for $1 \mathrm{~min}$, followed by $72^{\circ} \mathrm{C}$ for $5 \mathrm{~min}$. Quality control of $5 \mu \mathrm{l}$ of the second PCR product was performed on a $1.5 \%$ agarose gel with ethidium bromide.

Expression of the protein was done using RTS 100 E. coli HY Kit (Biotechrabbit, Hennigsdorf, Germany) following manufacturer's protocol. 


\section{KAPITEL 3}

A genome-wide association study reveals a locus for bilateral iridal hypopigmentation in Holstein Friesian cattle

veröffentlicht in:

BMC Genetics

$2017,18: 30$

DOI: $10.1186 / s 12863-017-0496-4$

URL: https://bmcgenet.biomedcentral.com/articles/10.1186/s12863-017-0496-4 


\section{A genome-wide association study reveals a locus for bilateral iridal hypopigmentation in Holstein Friesian cattle}

Anne K. Hollmann ${ }^{1}$, Martina Bleyer ${ }^{2}$, Andrea Tipold ${ }^{3}$, Jasmin N. Neßler ${ }^{3}$, Wilhelm E. Wemheuer $^{1}$, Ekkehard Schütz ${ }^{1}$ \& Bertram Brenig ${ }^{1}$

${ }^{1}$ Institute of Veterinary Medicine, University of Goettingen, 37077 Göttingen, Germany.

2 Pathology Unit, German Primate Center, Leibniz-Institute for Primate Research Göttingen, 37077 Göttingen, Germany.

${ }^{3}$ Small Animal Clinic, University of Veterinary Medicine Hannover, 30559 Hannover, Germany.

BMC Genetics

$2017,18: 30$

DOI: $10.1186 / \mathrm{s} 12863-017-0496-4$

URL: https://bmcgenet.biomedcentral.com/articles/10.1186/s12863-017-0496-4 


\section{Abstract}

\section{Background}

Eye pigmentation abnormalities in cattle are often related to albinism, Chediak-Higashi or Tietz like syndrome. However, mutations only affecting pigmentation of coat color and eye have also been described. Herein 18 Holstein Friesian cattle affected by bicolored and hypopigmented irises have been investigated.

\section{Results}

Affected animals did not reveal any ophthalmological or neurological abnormalities besides the specific iris color differences. Coat color of affected cattle did not differ from controls. Histological examination revealed a reduction of melanin pigment in the iridal anterior border layer and stroma in cases as cause of iris hypopigmentation. To analyze the genetics of the iris pigmentation differences, a genome-wide association study was performed using Illumina BovineSNP50 BeadChip genotypes of the 18 cases and 172 randomly chosen control animals. A significant association on bovine chromosome 8 (BTA8) was identified at position $60,990,733$ with a $-\log _{10}(p)=9 \cdot 17$. Analysis of genotypic and allelic dependences between cases of iridal hypopigmentation and an additional set of 316 randomly selected Holstein Friesian cattle controls showed that allele A at position $60,990,733$ on BTA8 $(P=4.0 \mathrm{e}-08$, odds ratio $=6.3,95 \%$ confidence interval 3.02-13.17) significantly increased the chance of iridal hypopigmentation.

\section{Conclusions}

The clinical appearance of the iridal hypopigmentation differed from previously reported cases of pigmentation abnormalities in syndromes like Chediak-Higashi or Tietz and seems to be mainly of cosmetic character. Iridal hypopigmentation is caused by a reduced content of melanin pigment in the anterior border layer and iridal stroma. A single genomic position on BTA8 was detected to be significantly associated with iridal hypopigmentation in examined cattle. To our knowledge this is the first report about this phenotype in Holstein Friesian cattle. 


\section{Background}

For many decades, eye color and eye color genetics has been an intensively studied field of research in humans and other species. More than 100 years ago, a relatively plain dominant-recessive model of inheritance of human brown and blue eye color has been assumed [1]. However, in recent years it became clear that iris pigmentation is under the control of a plethora of genes and is rather a quantitative than a simple Mendelian trait $[2,3]$.

Pigmentation of the eye, skin, and hair is the result of melanin pigment production in melanocytes. Melanin producing cells contain specialized lysosome-related organelles, the melanosomes, depositing melanin pigment in mature stage. Brighter colored eyes usually have less melanin pigment in iris stroma than darker eyes $[2,4,5]$. This and other factors as pigmentation of the posterior pigment epithelium [5], the type of melanin (euor pheomelanin) in iris melanocytes [5], light-scattering, and absorption processes [4] are believed to influence human eye color determination.

Changes in iris color have also been reported in cattle. Discolorations of the iris, either mono- or bilateral, complete or partial, are usually referred to as heterochromia iridis (HI). However, the phenotypic appearance differs remarkably between reported cases. The most prominent iris color variations were detected in cattle suffering from complete albinism, showing a pale blue iris with a white periphery $[6,7,8]$. Less distinct pigmentation anomalies were observed in non-albinotic $\mathrm{HI}$ cases, showing a bicolored iris with a central ring of blue and a peripheral ring of gray or brown $[9,10]$. Besides albinism, severe eye color changes in cattle were also observed in syndromes like Tietz [11] and Chediak-Higashi $[12,13]$. These syndrome related pigmentation alterations are usually accompanied by more restrictive anomalies. German Fleckvieh cattle with Tietz like syndrome exhibited bilateral deafness and colobomatous eyes [11]. Chediak-Higashi syndrome usually manifested in bruisability and bleeding tendency $[12,13]$. In albino cases with $\mathrm{HI}$ further clinical features related to eye development like nystagmus and blindness were detected [8].

Recently an alteration of iris coloration has been observed in Angus and Simmental breed. Affected cattle showed an oculocutaneous hypopigmentation $(\mathrm{OH})$ with a pale blue iris and a tan periphery coupled with a change in coat color from black to chocolate. 
It is assumed that this aberration was introduced into the Simmental breed in the late 1950 s by Angus founders and is inherited as an autosomal recessive trait. An amino acid exchange in the Ras-related Protein Rab-38 (RAB38) gene was identified as the disease causing mutation (Jon Beever, personal communication). Likewise, Rab38 cht $/$ Rab38 cht mice with a mutation (G146T) in exon 1 of Rab38 develop a similar phenotype with chocolate coat color and ocular hypopigmentation [14, 15].

In the current study the clinical, histological and molecular examination of bilateral iris hypopigmentation in 18 Holstein Friesian cattle are described. The aim of the study was the description of the phenotype, the identification of pigmentation alterations in the eye of affected cattle and the determination of the underlying genetics of iridal hypopigmentation in cattle.

\section{Methods}

\section{Animals, pedigree information and DNA samples}

A total of 18 Holstein Friesian (HF) cattle (9 male, 9 female) with hypopigmented irises originating from eight different farms were used for this study. Pedigree data were obtained from the German livestock database service provider (VIT) and checked for shared common ancestors. Complete pedigree data were available for ten individuals, while for eight animals only paternal pedigree data were present. Pedigrees of HF cases were constructed using Pedigraph [16].

DNA was extracted from EDTA-blood using MagNa Pure LC DNA Isolation Kit I (Roche Diagnostics Deutschland GmbH, Mannheim, Germany). Control DNA was obtained from the depository at the Institute of Veterinary Medicine (Göttingen, Germany).

\section{Histology}

To determine the exact cause of the hypopigmentation, histological evaluation of irises of unaffected and affected animals was conducted. Eyes of each animal were completely enucleated immediately after slaughtering. The dorsal half of each freshly enucleated eyeball was opened by incision of the sclera midway between the cornea and the optic 
nerve. After removal of the vitreous body, eyeballs were immersed in $4 \%$ phosphatebuffered formaldehyde. After fixation for at least $48 \mathrm{~h}$, lenses were removed and four cross sections were made through the anterior half of the eyeballs including dorsal, medial, ventral, and lateral aspects of the iris and adjacent structures of the anterior eye including ciliary body and cornea. Additionally, a cross section was prepared from the lens and from the caudal half of the eyeball at the level of the optic nerve. Trimmed tissue samples were paraffin-embedded, sectioned at $3 \mu \mathrm{m}$, and stained with hematoxylin and eosin (HE) for light microscopic examination.

\section{Genotyping, genome-wide association study (GWAS) and statistical analysis}

For GWAS 172 randomly selected HF cattle genotypes were used for GWAS. The 18 cases of iridal hypopigmentation were also genotyped using the Illumina BovineSNP50 BeadChip. Final reports were generated using GenomeStudio V2011.1 (Illumina, San Diego, USA) and imported into SNP \& Variation Suite (SVS) 8.5.0 (Golden Helix, Bozeman, USA). Genotype data were screened through a series of quality control criteria, including Mendelian errors, minor allele frequency $(\mathrm{MAF})<1 \%$, $\mathrm{p}$-value of Fisher's HardyWeinberg equilibrium (HWE) test $<0.001$ (based on controls), and single nucleotide polymorphism (SNP) call rate $<98 \%$ reducing the data set from 54,610 to 44,952 SNPs. Associations were calculated under an additive, recessive, and dominant model [17]. The additive genetic model fitted the data best. We did not detect significant evidance for population stratification. Genomic positions refer to NCBI UMD3.1.1.

Genotypic and allelic dependences were calculated between the 18 cases of iridal hypopigmentation and an additional set of randomly chosen 316 controls. Genotypes of this validation cohort were extracted from another data set generated using the Illumina BovineSNP50 BeadChip. Genotypes were compared using $3 \times 2$ or $2 \times 2$ contingency tables and Fisher's exact or $\chi^{2}$ statistics $(\mathrm{df}=2) . \quad \mathrm{P}<0.005$ was considered to be significant. Calculations were done using Microsoft Excel for Mac 2011 (14.7.1). HWE $\chi^{2}$-values were calculated according to Rodriguez et al. [18] and considered significant with $p>0.05$ $(d f=2)$. 
A genome-wide association study reveals a locus for bilateral iridal hypopigmentation in Holstein Friesian cattle

A haplotype association test was performed using a moving window of five markers. The expectation-maximization algorithm was applied using 50 iterations and a convergence tolerance of 0.0001 [19]. Results were corrected for multiple testing according to Bonferroni.

\section{Polymerase chain reaction (PCR) and sanger sequencing of $R A B 38$}

$R A B 38$ primers were designed using the online software tool Primer-Blast [20] with the following sequences RAB38_Ex1_F: 5'-CTTCCCGGGTCCGCAG-3', RAB38_Ex1_R: 5'-CTGGCACAGGAGATGGTCTG-3', RAB38_Ex2_F: 5'-ACTTTGCGGAGTGATCTGCT-3', RAB38_Ex2_R: 5'-GCTGCCTTAGCCACAAACAC-3', RAB38_Ex3_F: 5'-CATGGGAC

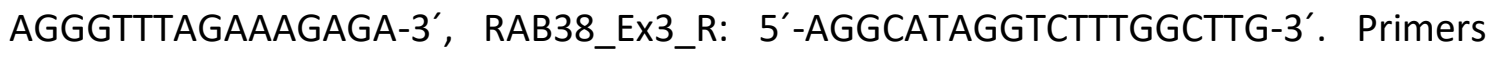
were designed to amplify the complete coding region including splice sites of RAB38. All primers were synthesized by Sigma-Aldrich (Steinheim, Germany). PCR was performed in a total volume of $25 \mu \mathrm{l}$ using FastStart Taq DNA Polymerase, dNTPack (Roche Diagnostics, Mannheim, Germany). One reaction mix (25 $\mu$ l) included 1.5 U Faststart Taq DNA Polymerase, $200 \mu \mathrm{mol} / \mathrm{L}$ dNTP, $0.4 \mu \mathrm{mol} / \mathrm{L}$ of each primer, 1x PCR reaction buffer (including $20 \mathrm{mM} \mathrm{MgCl}_{2}$ ), 1x Q-Solution (Qiagen, Hilden, Germany) and 40 ng of DNA. Cycling conditions were $95^{\circ} \mathrm{C}$ for $10 \mathrm{~min}$, followed by 30 cycles of $95^{\circ} \mathrm{C}$ for $30 \mathrm{sec}, 60^{\circ} \mathrm{C}$ for $30 \mathrm{sec}$ and $72{ }^{\circ} \mathrm{C}$ for $30 \mathrm{sec}$. Final elongation step was $72{ }^{\circ} \mathrm{C}$ for $5 \mathrm{~min}$. PCR products were sequenced with the BigDye Terminator v3.1 Cycle Sequencing Kit (Applied Biosystems, Fisher Scientific GmbH, Schwerte, Germany) on an ABI PRISM 3130xI Genetic Analyzer (Life Technologies, Foster City, USA) after purification using Rapid PCR Cleanup Enzyme Set (New England Biolabs GmbH, Frankfurt am Main, Germany). As reference sequence of $R A B 38$ assembly UMD3.1.1 with accession number AC_000186.1 was used. 


\section{Results}

\section{Comprehensive clinical examination of affected cattle}

As shown in Fig. 1, affected HF cattle had a normal, breed specific coat color with no obvious color deviations of eyelids and eyelashes. Furthermore, cases did not show any neurological deficits, i.e. disturbance of the level of consciousness, mentation and behaviour, posture and gait, postural reactions, as well as spinal and cranial nerve function [21]. Signs of a Horner syndrome, which has been described in conjunction with $\mathrm{HI}$ in humans, were absent $[22,23]$. Pupillary light and blink reflex were normal. No spontaneous nystagmus or strabismus could be observed. The animals had a physiological nystagmus. The ocular fundus was normal, a retinitis pigmentosa was excluded. To exclude common infectious diseases, animals were also tested for bovine viral diarrhea virus (bovine virus diarrhea), bovine herpesvirus type 1 virus (infectious bovine necrotic rhinotracheitis), bovine leukaemia virus (bovine lymphomatosis), Brucella spp. (bovine brucellosis), bluetongue virus (bluetongue disease), Mycobacterium paratuberculosis (paratuberculosis), Schmallenberg virus and Neospora caninum (bovine neosporosis). All test results were negative. Summarizing the clinical analysis of the examined animals, a bilateral hypopigmentation caused by a hitherto unknown genetic variation strictly affecting iridal coloration was suspected. As the affected animals did not show any other anomalies, syndromes like Chediak-Higashi or Tietz were excluded. 

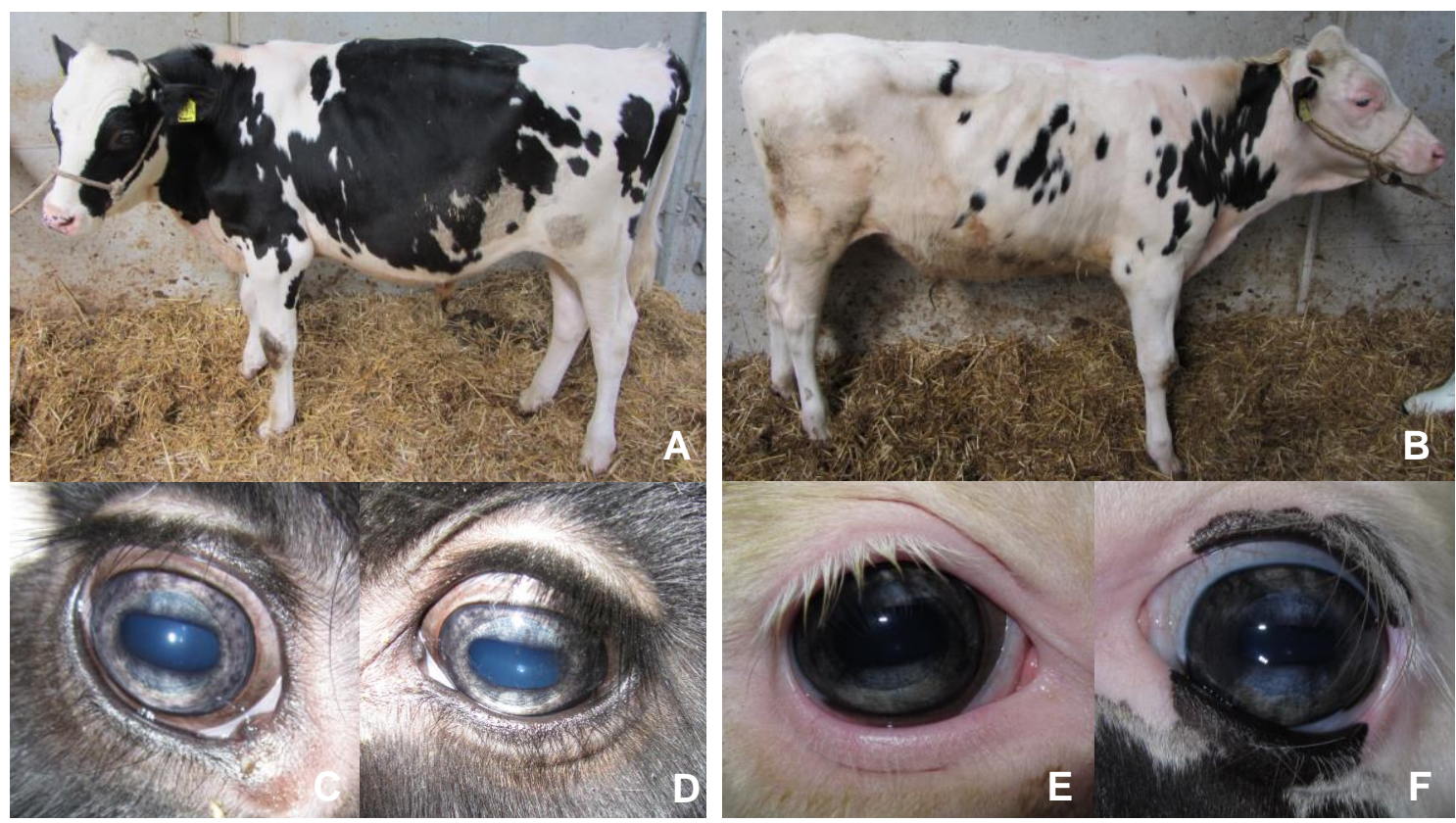

Fig. 1 Phenotypic appearance of iridal hypopigmentation.

HF cattle were ophthalmological and neurological examined and irises underwent histologic evaluation. A and B: Coat color of affected cattle was typical for the breed and without any sign for albinism. Both cattle were normally developed at time of examination. $\mathrm{C}-\mathrm{F}$ : Iris color of cases $\mathrm{A}$ and $\mathrm{B}$. The degree of discoloration clearly differed between cases. All affected cattle showed a bicolored iris with a central ring of silverblue and a peripheral ring of brown-gray. Iris color within one iris showed alternating darker and lighter parts.

Detailed ophthalmological examination of the irises of affected animals showed two merging, but clearly differentiable shades of color, a bluish center and a grayish peripheral ring. Although all animals showed a clear discoloration of the iris, there was considerable variation of iris coloration between animals. The color of the central iridal parts ranged from silvery-blue to gray-blue with darker and lighter parts. In the periphery, irises were light brown to gray with occasional light gray zones (Fig. 1). In some animals, the degree of discoloration differed within the peripheral iris and showed alternating darker and lighter regions. Partial brownish corneoscleral pigmentation was visible in a few animals. 
A genome-wide association study reveals a locus for bilateral iridal hypopigmentation in Holstein Friesian cattle

\section{Determination of common ancestors}

To identify a potential founder of the eye color phenotype, a pedigree analysis was performed. Available pedigree data of HF cattle revealed that the 18 cases descended from 11 different sires whereas dams were not closely related. None of the dams had been reported to show the typical iris hypopigmentation. In total 10 male ancestors, born between 1954 and 1983, were identified being present in the dam and sire line of every case. The available pedigree data did not reveal a single common founder for HF cases, and HF cases were not closely related.

\section{Histological examinations}

Histological evaluation of irides revealed less melanin pigment deposition in the anterior border layer and the iridal stroma in the affected animals compared to the normal iris of the unaffected control animals (Fig. 2). This form of hypopigmentation was evident in all examined localizations of the irises in the affected animals. Only the degree of hypopigmentation varied between the different analysed regions and within irises at the same locations. In general, hypopigmentation seemed to be more pronounced in central iridal parts (pupillary zone and central parts of the ciliary zone) and in the dorsal as well as ventral iris. Iridal thickness, stromal density, and cellular composition were consistent in all examined animals. Differences in pigmentation of the posterior pigmented epithelium of the iris, other uveal structures (ciliary body, choroid), as well as of the retinal pigment epithelium were not detected. All other examined ocular structures were inconspicuous. 


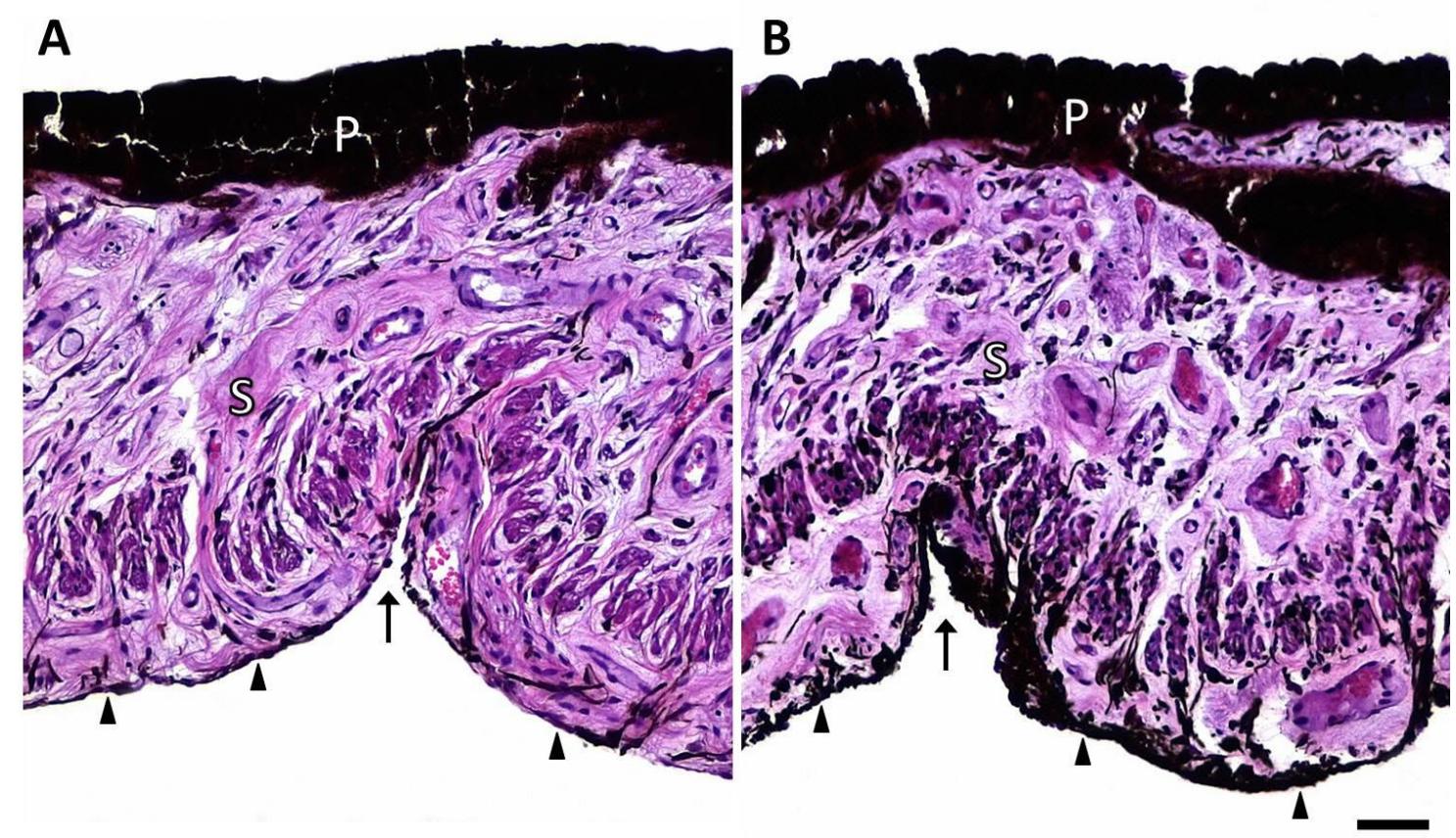

Fig. 2 Histological cross section through the ciliary zone of the left ventral iris near the collarette with characteristic Fuchs' crypts.

Comparison of the pigmentation of the three different iris layers anterior border layer (arrowheads), stroma (S), and posterior pigmented epithelium (P) of affected (A) and control animals (B). A distinct hypopigmentation of the anterior border layer (arrowheads) and the iridal stroma (S) in the affected animal (A) can be observed compared to the unaffected control animal (B). Thickness and pigment content of the double-layered posterior pigmented epithelium $(P)$ is similar in both animals. HE staining, scale bar $=50 \mu \mathrm{m}$.

\section{Determination of associated chromosomal regions}

To identify associated chromosomal regions a genome-wide association study was performed. The 18 cases were compared to 172 unrelated control cattle. Seven highly associated SNPs above the Bonferroni genome-wide significance level were identified on bovine chromosome 8 (BTA8) spanning from 57.3-65.3 Mb (Fig. 3; Additional file 1: Table S1). The SNP with the highest $-\log _{10}(p)=9.17$ (BTB-00352779) was located at position 60,990,733 (NCBI UMD3.1.1). It is noteworthy that six genes, i.e. CLTA, GNE, RNF38, SHB, TRIM14, and NANS, located in the region from 57.3-65.5 Mb on BTA8 have been associated with earlobe color in chicken [24]. However, so far none of these genes have been reported to be directly involved in eye pigmentation. 


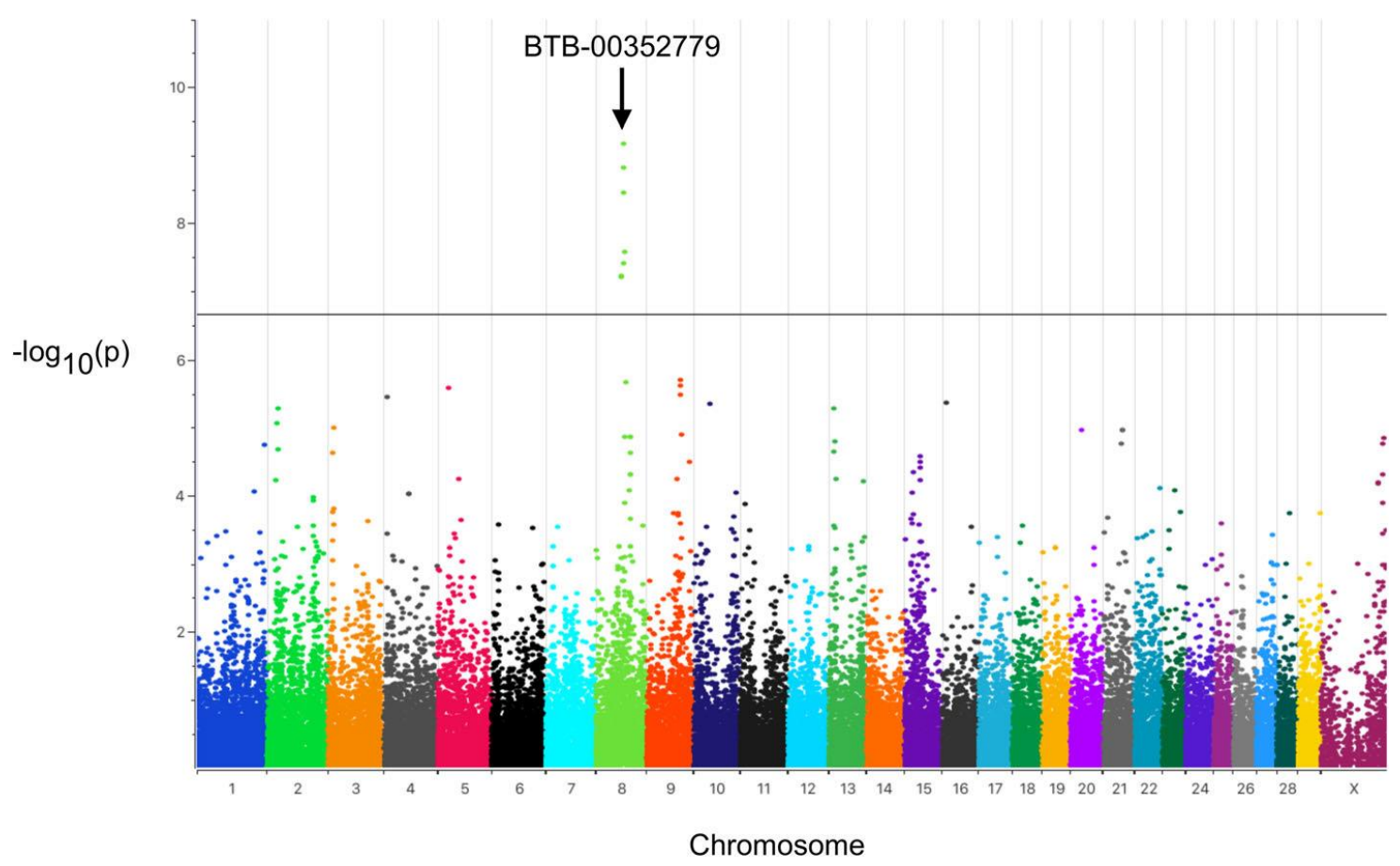

Fig. 3 Manhattan plot of $-\log _{10}(p)$-values for SNPs by genomic location (NCBI UMD3.1.1).

Calculations were performed using SNP data of 18 cases and 172 randomly selected control HF cattle. The black line indicates the Bonferroni genome-wide significance level of $-\log _{10}(p)=6.65$ at $p<0.01$. The marker with the highest $-\log _{10}(p)$-value is indicated (BTB-00352779).

To validate the identified associations and to determine the genotypic and allelic dependences compared with an unrelated additional control cohort, 316 Holstein Friesian cattle were randomly selected from a previously generated data set and compared with the genotypes of the 18 cases. Table 1 summarizes the results and statistics of the comparison of the genotypes. Both groups (cases/controls) were in Hardy-Weinberg equilibrium at BTB-00352779 (cases: $\chi^{2}=5.8$, controls: $\chi^{2}=0.72$ ). However, as determined by using a $3 \times 2$ contingency table and Fisher's exact statistics genotypes were significantly not independent at BTB-00352779 with $P=6.19 \mathrm{e}-07$. To evaluate which allele was associated with a higher risk of developing an iridal hypopigmentation, odds ratios were calculated (Table 2). As shown in Table 2 alleles were significantly dependent using a $2 \times 2$ contingency table and $\chi^{2}$-statistics. The 
A genome-wide association study reveals a locus for bilateral iridal hypopigmentation in Holstein Friesian cattle

presence of the A-allele was leading to a 6.3-times higher chance to develop an iridal hypopigmentation (95\% Cl: 3.0172-13.1727). Using a moving window of five SNPs a haplotype association was calculated for the 18 cases. Highly significant associations were detected for five haplotypes including BTB-00352779 and flanking markers (Table 3). Haplotype AAAAA with BTB-00352779 as first marker showed the highest odds ratio $(\mathrm{OR}=8.31 ; 95 \% \mathrm{Cl}: 3.62-19.08)$.

Table 1 Genotypic dependences of iridal hypopigmentation

\begin{tabular}{|c|c|c|c|c|c|c|c|c|}
\hline \multirow[t]{2}{*}{ SNP (chromosome) } & \multirow[t]{2}{*}{ Genotype } & \multicolumn{3}{|c|}{ Cases $(n=18)$} & \multicolumn{3}{|c|}{ Controls $(n=316)$} & \multirow[t]{2}{*}{ P-value } \\
\hline & & Obs. & Exp. & $\mathrm{HWE}^{1)}$ & Obs. & Exp. & $\mathrm{HWE}^{1)}$ & \\
\hline \multirow{3}{*}{$\begin{array}{l}\text { BTB-00352779 } \\
\text { (BTA8) }\end{array}$} & CC & 5 & 14.5 & & 265 & 254.9 & & \\
\hline & $A C$ & 13 & 3.4 & & 50 & 60.2 & & \\
\hline & AA & 0 & 0.1 & 5.8 & 1 & 0.9 & 0.72 & $6.19 e-07$ \\
\hline
\end{tabular}

1) HWE: Hardy-Weinberg equilibrium $\chi^{2}$-value $(p>0.05, d f=2)$; Obs.: Observed number of genotypes; Exp.: Expected number of genotypes; P-value: Determined using a $3 \times 2$ contingency table and Fisher's Exact statistics (two-tailed).

Table 2 Allelic dependences of iridal hypopigmentation

\begin{tabular}{|c|c|c|c|c|c|c|c|c|c|}
\hline \multirow[t]{2}{*}{$\begin{array}{l}\text { SNP } \\
\text { (chromosome) }\end{array}$} & \multirow[t]{2}{*}{ Allele } & \multicolumn{2}{|c|}{$\begin{array}{l}\text { Cases } \\
(\mathrm{n}=18)\end{array}$} & \multicolumn{2}{|c|}{$\begin{array}{l}\text { Controls } \\
(n=316)\end{array}$} & \multirow[t]{2}{*}{$\chi^{2}$} & \multirow[t]{2}{*}{ P-value } & \multirow[t]{2}{*}{ OR } & \multirow[t]{2}{*}{$0.95 \mathrm{Cl}$} \\
\hline & & Obs. & Exp. & Obs. & Exp. & & & & \\
\hline \multirow[t]{2}{*}{$\begin{array}{l}\text { BTB-00352779 } \\
\text { (BTA8) }\end{array}$} & C & 23 & 32.5 & 580 & 570.5 & & & 0.16 & $\begin{array}{l}0.076- \\
0.3314\end{array}$ \\
\hline & A & 13 & 3.5 & 52 & 62.5 & 30.15 & $4.0 \mathrm{e}-08$ & 6.3 & $\begin{array}{l}3.0172- \\
13.1727\end{array}$ \\
\hline
\end{tabular}

Obs.: Observed number of alleles; Exp.: Expected number of alleles; $\chi^{2}, p$-value: $\chi^{2}$ - and $p$-values were determined using a $2 \times 2$ contingency table and $\chi^{2}$-statistics; OR: Odds ratio; $0.95 \mathrm{Cl}$ : $95 \%$ confidence intervals. 
A genome-wide association study reveals a locus for bilateral iridal hypopigmentation in Holstein Friesian cattle

Table 3 Haplotype association analysis for markers flanking BTB-00352779

\begin{tabular}{|c|c|c|c|c|c|c|}
\hline First Marker ${ }^{\mathrm{a})}$ & Position $^{\text {b) }}$ & Haplotype & $-\log _{10}(p)$ & $(p)_{B}^{c)}$ & $\mathrm{OR}^{\mathrm{d})}$ & $0.95 \mathrm{Cl}^{\mathrm{e})}$ \\
\hline \multirow[t]{7}{*}{ ARS-BFGL-NGS-40630 } & 60800770 & AGAGC & 0.57 & 1 & 0.65 & $0.30-1.40$ \\
\hline & & GAGGC & 0.02 & 1 & 1.02 & $0.46-2.27$ \\
\hline & & GGAGC & 1.16 & 1 & 0.28 & $0.07-1.20$ \\
\hline & & AAAGA & 7.63 & 0.0085 & 7.90 & $3.46-18.04$ \\
\hline & & AGAAC & 0.15 & 1 & 0.67 & $0.09-5.24$ \\
\hline & & AAAGC & 0.54 & 1 & & \\
\hline & & AAGGC & 0.45 & 1 & 0.04 & \\
\hline \multirow[t]{6}{*}{ ARS-BFGL-NGS-115798 } & 60823250 & GAGCA & 0.52 & 1 & 0.67 & $0.31-1.44$ \\
\hline & & AGGCA & 0.10 & 1 & 0.90 & $0.40-2.00$ \\
\hline & & GAGCC & 1.21 & 1 & 0.27 & $0.06-1.17$ \\
\hline & & AAGAA & 7.62 & 0.0087 & 7.90 & $3.46-18.04$ \\
\hline & & GAACA & 0.19 & 1 & 0.61 & $0.08-4.78$ \\
\hline & & AAGCC & 0.54 & 1 & & \\
\hline \multirow[t]{5}{*}{ ARS-BFGL-NGS-12436 } & 60872538 & AGCAA & 0.51 & 1 & 0.67 & $0.31-1.45$ \\
\hline & & GGCAA & 0.10 & 1 & 0.90 & $0.40-1.99$ \\
\hline & & AGCCG & 1.57 & 1 & 0.22 & $0.05-0.95$ \\
\hline & & AGAAA & 7.62 & 0.0087 & 7.90 & $3.46-18.04$ \\
\hline & & AACAG & 0.19 & 1 & 0.61 & $0.08-4.78$ \\
\hline \multirow[t]{5}{*}{ ARS-BFGL-NGS-102 } & 60952836 & GCAAA & 0.68 & 1 & 0.64 & $0.31-1.30$ \\
\hline & & GCCGA & 0.71 & 1 & 0.39 & $0.09-1.70$ \\
\hline & & GAAAA & 7.72 & 0.0069 & 7.99 & $3.50-18.23$ \\
\hline & & GCCGG & 1.14 & 1 & & \\
\hline & & ACAGA & 0.19 & 1 & 0.62 & $0.08-4.83$ \\
\hline \multirow[t]{5}{*}{ BTB-00352779 } & 60990733 & CAAAG & 0.76 & 1 & 0.61 & $0.30-1.25$ \\
\hline & & CCGAG & 0.68 & 1 & 0.40 & $0.09-1.75$ \\
\hline & & AAAAA & 7.97 & 0.0038 & 8.31 & $3.62-19.08$ \\
\hline & & CCGGG & 1.12 & 1 & & \\
\hline & & CAGAG & 0.18 & 1 & 0.64 & $0.08-4.96$ \\
\hline
\end{tabular}

a) A moving window of 5 SNPs was used to determine haplotype associations. Each haplotype begins with the listed first SNP followed by four of the following consecutive SNPs: ARS-BFGLNGS-40630, ARS-BFGL-NGS-115798, ARS-BFGL-NGS-12436, ARS-BFGL-NGS-102, BTB00352779, Hapmap39688-BTA-81545, Hapmap49326-BTA-81546, ARS-BFGL-NGS-55438, Hapmap36177-SCAFFOLD210634_2319 


\footnotetext{
b) Positions according to NCBI UMD3.1.1

c) Bonferroni corrected $p$-value

d) OR: Odds ratio

e) $95 \%$ confidence interval upper and lower limit
}

\section{Exclusion of $R A B 38$ as candidate for bilateral iridal hypopigmention}

Although the analysed cases of iridal hypopigmentation did not show the typical phenotype described for oculocutaneous hypopigmentation $(\mathrm{OH})$ in Angus and Simmental cattle, i.e. eyes with pale blue irises around the pupil, a tan periphery and slightly bleached black coats looking grey or red, bovine RAB38 was screened for mutations in the 20 cases and controls. In addition, RAB38 is located on BTA29 which did not show any associated SNP in the GWAS. However, to exclude RAB38 as causative for iridal hypopigmentation coding regions including splice sites were amplified and fragments sequenced. As expected no disease causing polymorphisms or alterations from the reference genome for cases and controls were detected.

\section{Discussion}

Iridal hypopigmentation in cattle is attributed to a reduced content of melanin pigment in the anterior border layer and iridal stroma. These findings clearly differ from previously reported histological observations in $\mathrm{HI}$ cases, showing a reduction in eye pigmentation in different uveal structures as different iris layers, retinal pigment epithelium (RPE) [8], and choroid [6, 25]. Leipold and Huston observed a non-albinotic case of $\mathrm{HI}$ with reduced iris pigmentation in anterior border layer, iris stroma, and posterior pigment epithelium in Hereford cattle. Pigmentation in the remaining pigmented eye structures was also reduced and iridal stroma was hypoplastic [25]. Iris hypopigmentation in cases was exclusively located in the anterior border layer and the iridal stroma, and no structures were fully devoid of pigment. Pigmentation differences as seen in the present cases of iris hypopigmentation seemed to be rather comparable with naturally occuring eye color variances in humans than to HI. Human eye color variance is mainly due to differences in the amount of melanin pigment in the anterior 
border layer and iridal stroma. Pale colored eyes generally contain less melanin compared to brown eyes $[2,5]$.

In cattle with iris hypopigmentation, gradual iridal brightening can be explained by a reduced melanin content of variable intensity affecting the anterior border layer and the iridal stroma, resulting in blue to gray-brown instead of the normal black color. Differences in coloration between central and peripheral parts of the iris, namely the rather bluish color of the central iridal ring and the gray to light brown color of peripheral iridal parts, are probably attributed to the increasing thickness of the iris towards the periphery, associated with increased amounts of collagen in the peripheral iridal stroma. As the amount of collagen fibres within the iridal stroma is known to be another important determining factor of eye color, at least in humans [2], it may be assumed that variations in iris brightening between central and peripheral iridal parts in cattle with iris hypopigmentation result from differences in the amount of collagen and, thus, in the backscattering properties of the respective iridal regions. In this respect it is noteworthy that in the associated region on BTA8 collagen gene COL15A1 is located at position $64,437,276-64,540,739$ which has been shown to be expressed in multiple ocular structures [26]. In contrast, the amount of collagen in the iridal stroma of normal dark brown to black-eyed cattle seems to have a minor influence on iris coloration as almost all light is probably absorbed by the extensive eumelanin deposits in the anterior border layer and the iridal stroma accounting for a homogenous dark eye color $[27,28]$. Variations of the degree of discoloration within the peripheral iris with alternating darker and lighter regions in affected animals of the present study are caused by regional differences in the melanin content of the anterior border layer and the iridal stroma, which were confirmed by histological analyses.

Taking all clinical findings together, there were no other abnormalities found in conjunction with the iris hypopigmentation. Although no long-term effects were examined, iris hypopigmentation seems to be mainly of cosmetic character. Under physiological conditions melanin pigment protects from ultraviolet (UV) light, and humans with lighter eye color seem to be more susceptible to age related macula degeneration [29] and uveal melanoma [30,31]. This is comparable with blue-eyed horses that are at higher risk to develop ocular squamous cell carcinoma [32]. 


\section{Conclusion}

The bilateral iridal hypopigmentation in HF cattle described here was due to a reduction of melanin pigment in the anterior border layer and iridal stroma. The phenotype was highly associated with a chromosomal region on BTA8. Haplotype association analysis showed that the presence of the A-alleles at the associated SNPs significantly increased the chance of developing an iridal hypopigmentation.

\section{Acknowledgements}

The authors thank M. Scharfenstein, S. Loos, L. Jüttner, and S. Pach for their excellent technical assistance. The German livestock database service provider (VIT) is thanked for providing pedigree data. The cattle breeders are thanked for providing samples and pictures of cases. We are grateful to H. B. Urnovitz for critical review of the manuscript. We acknowledge support by the German Research Foundation and the Open Access Publication Funds of the Göttingen University.

\section{Ethics approval}

The current study was performed according to the ethical guidelines of the University of Goettingen and the German Animal Welfare act. Genotyping data and blood sampling are based on routine diagnostic parentage control and genomic selection programs performed with written owner consent. Collection of blood samples was conducted exclusively by local veterinarians. Blood sampling by veterinarians with state examination is in accordance with the German Animal Welfare Act ( $\$ 6$ Abs. 1 Satz 2 TierSchG). Therefore no formal ethical approval was required, since no other samples were collected for this study. Animals were regularly slaughtered at an abattoir according to $\S 4$ of the German Animal Welfare Act. 


\section{References}

1. Davenport GC, Davenport CB. Heredity of eye-color in man. Science. 1907; 26(670): 589-92.

2. Sturm RA, Larsson M. Genetics of human iris colour and patterns. Pigment Cell Melanoma Res. 2009; 22(5): 544-62.

3. Edwards $M$, Cha D, Krithika S, Johnson M, Cook G, Parra EJ. Iris pigmentation as a quantitative trait: variation in populations of European, East Asian and South Asian ancestry and association with candidate gene polymorphisms. Pigment Cell Melanoma Res. 2016; 29(2): 141-62.

4. Zhu G, Evans DM, Duffy DL, Montgomery GW, Medland SE, Gillespie NA, Ewen $\mathrm{KR}$, Jewell M, Liew YW, Hayward NK, et al. A genome scan for eye color in 502 twin families: most variation is due to a QTL on chromosome 15q. Twin Res. 2004; 7(2): 197-210.

5. Rennie IG. Don't it make my blue eyes brown: heterochromia and other abnormalities of the iris. Eye (Lond). 2012; 26(1): 29-50.

6. Leipold HW, Huston K. A Herd of glass-eyed albino Hereford cattle. J Hered. 1966; 57(5): 179-82.

7. Leipold HW, Huston K, Gelatt KN. Complete Albinism in a Guernsey Calf. J Hered. 1968; 59(3): 218-20.

8. Jayasekera U, Leipold HW. Albinism in United-States Charolais Cattle. Ann Genet Sel Anim. 1981; 13(3): 213-8.

9. Leipold HW, Huston K. Incomplete albinism and heterochromia irides in Herefords. J Hered. 1968; 59(1): 3-8.

10. Huston K, Leipold HW, Freeman AE. Heterochromia Irides in Dairy Cattle. J Dairy Sci. 1968; 51(7): 1101-2.

11. Philipp U, Lupp B, Momke S, Stein V, Tipold A, Eule JC, Rehage J, Distl O. A MITF Mutation Associated with a Dominant White Phenotype and Bilateral Deafness in German Fleckvieh Cattle. Plos One. 2011; 6(12): e28857.

12. Padgett GA, Leader RW, Gorham JR, O ' Mary CC. The Familial Occurrence of the Chediak-Higashi Syndrome in Mink and Cattle. Genetics. 1964; 49: 505-12.

13. Shiraishi $M$, Ogawa $H$, Ikeda $M$, Kawashima $S$, Ito K. Platelet dysfunction in Chediak-Higashi syndrome-affected cattle. J Vet Med Sci. 2002; 64(9): 751-60. 
14. Loftus SK, Larson DM, Baxter LL, Antonellis A, Chen Y, Wu X, Jiang Y, Bittner M, Hammer 3rd JA, Pavan WJ. Mutation of melanosome protein RAB38 in chocolate mice. Proc Natl Acad Sci U S A. 2002; 99(7): 4471-6.

15. Brooks BP, Larson DM, Chan CC, Kjellstrom S, Smith RS, Crawford MA, Lamoreux $L$, Huizing $M$, Hess $R$, Jiao $X$, et al. Analysis of ocular hypopigmentation in Rab38cht/cht mice. Invest Ophthalmol Vis Sci. 2007; 48(9): 3905-13.

16. Garbe JR, Da Y. Pedigraph: a software tool for the graphing and analysis of large complex pedigree. User manual Version 24 Department of Animal Science, University of Minnesota 2008. Available: https://animalgene.umn. edu/pedigraph. Accessed 28 Mar 2017.

17. Bae H, Perls $T$, Steinberg M, Sebastiani P. Bayesian polynomial regression models to fit multiple genetic models for quantitative traits. Bayesian Anal. 2015; 10(1): 53-74.

18. Rodriguez S, Gaunt TR, Day IN. Hardy-Weinberg equilibrium testing of biological ascertainment for Mendelian randomization studies. Am J Epidemiol. 2009; 169(4): 505-14.

19. Excoffier L, Slatkin M. Maximum-likelihood estimation of molecular haplotype frequencies in a diploid population. Mol Biol Evol. 1995; 12(5): 921-7.

20. Ye J, Coulouris G, Zaretskaya I, Cutcutache I, Rozen S, Madden TL. Primer- BLAST: a tool to design target-specific primers for polymerase chain reaction. BMC Bioinformatics. 2012; 13(1): 1-11.

21. Mayhew IGJ. Large animal neurology. Oxford: Wiley-Blackwell; 2009.

22. Renard D, Jeanjean L, Labauge P. Heterochromia Iridis in congenital Horner' $S$ syndrome. Eur Neurol. 2010; 63(4): 253.

23. Diesenhouse MC, Palay DA, Newman NJ, To K, Albert DM. Acquired heterochromia with horner syndrome in two adults. Ophthalmology. 1992; 99(12): 1815-7.

24. Nie C, Zhang Z, Zheng J, Sun H, Ning Z, Xu G, Yang N, Qu L. Genome-wide association study revealed genomic regions related to white/red earlobe color trait in the Rhode Island red chickens. BMC Genet. 2016; 17(1): 115.

25. Leipold HW, Huston K. Histopathology of incomplete albinism and heterochromia irides in the Hereford. Cornell Vet. 1969; 59(1): 69-75.

26. Wiggs JL, Howell GR, Linkroum K, Abdrabou W, Hodges E, Braine CE, Pasquale LR, Hannon GJ, Haines JL, John SW. Variations in COL15A1 and COL18A1 influence age of onset of primary open angle glaucoma. Clin Genet. 2013; 84(2): 167-74. 
27. Wilkerson $\mathrm{CL}$, Syed NA, Fisher MR, Robinson NL, Wallow IL, Albert DM. Melanocytes and iris color: light microscopic findings. Arch Ophthalmol. 1996; 114(4): 437-42.

28. Liu Y, Hong L, Wakamatsu K, Ito S, Adhyaru BB, Cheng CY, Bowers CR, Simon JD. Comparisons of the structural and chemical properties of melanosomes isolated from retinal pigment epithelium, iris and choroid of newborn and mature bovine eyes. Photochem Photobiol. 2005; 81(3): 510-6.

29. Frank RN, Puklin JE, Stock C, Canter LA. Race, iris color, and age-related macular degeneration. Trans Am Ophthalmol Soc. 2000; 98: 109-17.

30. Gallagher RP, Elwood JM, Rootman J, Spinelli JJ, Hill GB, Threlfall WJ, Birdsell JM. Risk factors for ocular melanoma: Western Canada Melanoma study. J Natl Cancer Inst. 1985; 74(4): 775-8.

31. Schmidt-Pokrzywniak A, Jockel KH, Bornfeld N, Sauerwein W, Stang A. Positive interaction between light iris color and ultraviolet radiation in relation to the risk of uveal melanoma: a case-control study. Ophthalmology. 2009; 116(2): 340-8.

32. Bergstrom BE, Labelle AL, Pryde ME, Hamor RE, Myrna KE. Prevalence of ophthalmic disease in blue-eyed horses. Equine Vet Educ. 2014; 26(8): 438-40.

\section{Additional files}

Table S1 Details of markers on BTA8 associated with iridal hypopigmentation in HF cattle

\begin{tabular}{|c|c|c|c|}
\hline Marker & Position $^{1)}$ & Obs. $-\log _{10}(p)^{2)}$ & Exp. $-\log _{10}(p)$ \\
\hline BTA-108808-no-rs & 57307140 & 7.21 & 3.91 \\
\hline BTB-00349451 & 57403486 & 7.2 & 3.84 \\
\hline BTB-00352779 & 60990733 & 9.17 & 4.95 \\
\hline Hapmap36177-SCAFFOLD210634_2319 & 61115517 & 8.81 & 4.47 \\
\hline Hapmap40026-BTA-81432 & 61213362 & 8.44 & 4.25 \\
\hline BTB-00351461 & 61777605 & 7.39 & 3.99 \\
\hline BTA-19347-no-rs & 65295376 & 7.54 & 4.10 \\
\hline
\end{tabular}

1) Positions according to NCBI UMD3.1.1

2) Bonferroni genome-wide significance level of $-\log _{10}(p)=6.65(p<0.01)$ 
KAPITEL 4

Allgemeine Diskussion 


\section{$4 \quad$ Allgemeine Diskussion}

In der vorliegenden Arbeit wurden Analysen zur Aufklärung potentiell pathologisch assoziierter genetischer Aberrationen bei den hereditären Augenerkrankungen kongenitale Katarakt und Irishypopigmentierung des HF Rinds durchgeführt.

Als Grundlage beider Studien diente Probenmaterial deutscher Rinder der Rasse Holstein Friesian. Das Zuchtziel für deutsche Holstein Kühe wurde vom Deutschen Holstein Verband e.V. (DHV) im Jahre 2013 wie folgt festgelegt:

„Deutsche Holsteins der Farbrichtung Schwarzbunt und Rotbunt werden auf hohe Lebensleistung gezüchtet. Ziel ist die wirtschaftliche Leistungskuh in milchbetontem Typ, die durch stabile Gesundheit, Robustheit und gute Fruchtbarkeit viele Laktationen nutzbar ist und über ein entsprechendes Entwicklungspotenzial mit hohem Futteraufnahmevermögen und optimaler Futterverwertung verfügt" (Deutscher Holstein Verband e.V., 2013).

Diese breitgefächerten Zielformulierungen zeigen, dass neben der Milchleistung auch die Gesundheit der Tiere eine zentrale Rolle im Zielkanon des Verbandes einnimmt.

Die Zuchtstrategien der letzten Jahrzehnte führten allerdings zur Erhöhung des Inzuchtkoeffizienten (Koenig und Simianer, 2006) und damit einhergehend zur Zunahme von Anpaarungen genetisch verwandter Elterntiere. In diesem Sachverhalt liegt wiederum die Ursache für das erhöhte Risiko hinsichtlich des Auftretens rezessiver Gendefekte (Koenig und Simianer, 2006; Fritz et al., 2013).

Die wohl bedeutendsten Beispiele molekulargenetisch aufgeklärter Gendefekte in der Holsteinzucht sind die Bovine Leukozytenadhäsionsdefizienz (BLAD) (Shuster et al., 1992), die Komplexe Vertebrale Missbildung (CVM) (Thomsen et al., 2006), Brachyspina (Charlier et al., 2012), das Cholesterol-Defizit-Syndrom (CDH) (Menzi et al., 2016; Schütz et al., 2016) sowie die Holstein Haplotypen HH1 (Fritz et al., 2013), HH3 (McClure et al., 2014), HH4 (Fritz et al., 2013) und HH5 (Schütz et al., 2016). In der Regel konnte der Ursprung aller oben genannten Gendefekte auf jeweils ein Gründertier zurückgeführt werden.

Neben dem Wissen über potentielle Begründer einer Erkrankung ist vor allem die Identifikation von Anlageträgern einer Erbkrankheit in der Population wichtig. Durch molekulargenetische Bestimmung eines zugrunde liegenden spezifischen Gendefekts 
ergibt sich die Möglichkeit mittels Genotypisierung Anlageträger zu identifizieren und daraufhin durch Ausschluss aus der Zucht bzw. gezielte Anpaarungen mit NichtAnlageträgern eine Eindämmung des Defekts zu erreichen. Allerdings muss erwähnt werden, dass es sich bei der kongenitalen Katarakt und der Irishypopigmentierung nicht um letale Defekte handelt. Dennoch sollte, besonders im Fall der Linsentrübungen, eine Ausbreitung des Defekts vermieden werden.

Obgleich das Auftreten von kongenitaler Katarakt die Tiere nicht automatisch aus der Milchproduktion ausschließt, ist doch anzunehmen, dass es durch die massive Verminderung des Sehvermögens betroffener Rinder zu Beeinträchtigungen in der Haltung der Tiere kommt. Zudem wurden in der vorliegenden Studie bei allen ophthalmologisch untersuchten Tieren sekundäre Augenerkrankungen diagnostiziert (vgl. Kapitel 2, S1 Table). Diese Augenerkrankungen waren allesamt nicht kongenital und entwickelten sich als Folge des zunehmenden Zerfalls der Linsenstruktur. Durch die Typisierung von potentiellen Anlageträgern in der Population könnten diese Effekte vermieden und eine Eindämmung des Defekts erreicht werden.

Bei den HF Rindern der untersuchten Studienkohorte wurde aufgrund der Abstammungsdaten eine familiäre Verbreitung des Merkmals mit autosomal rezessiver Vererbung angenommen. Zudem konnte ein potentieller Begründer (Tier \#760, geboren 1982, vgl. Kapitel 2, Fig 2) der Erkrankung identifiziert werden. Durch die Identifikation der mit kongenitaler Katarakt assoziierten Mutation im CPAMD8-Gen (g.5995966C>T) konnte dieser Bulle, ebenso wie einige seiner Nachkommen, als Anlageträger bestätigt werden. Ebenfalls wird es nun möglich sein, durch zielgerichtete Genotypisierung bezüglich der genannten Mutation, weitere, in der Studie noch nicht untersuchte Rinder der Rasse Holstein-Rotbunt auf eine Anlageträgerschaft hin zu untersuchen.

Die betroffenen Rinder der Studie wurden im Zeitraum von 2007-2012 geboren und gehörten, mit einer Ausnahme (Holstein-Schwarzbunt), der Rasse Holstein-Rotbunt an. Das vermehrte Auftreten von Rindern mit kongenitaler Katarakt in den Jahren 2007-2012 lässt sich durch die Besamungszahlen der Väter bzw. Mutterväter (die Bullen mit den internen Nummern \#870, \#977, \#890 und \#053, vgl. Kapitel 2) erklären. Die Tabelle A1 im Anhang fasst diese Zahlen für die relevanten Jahre zusammen, sofern die Bullen unter den zehn meisteingesetzten Bullen der jeweiligen Jahre rangierten. So gehörte der Vererber \#870, welcher Vater von 26 der 31 betroffenen Rinder ist, in den 
Jahren 2008-2012 zu den zehn meist eingesetzten Bullen in der Holstein-Rotbunt Zucht. Die drei Mutterväter (\#977, \#890 und \#053) hingegen gehörten dieser Gruppe in den Zeiträumen von 2002-2003 (\#977), 2004-2008 (\#890) und 2005-2006 (\#053) an (Arbeitsgemeinschaft deutscher Rinderzüchter (ADR), 2004-2013).

Heute rangieren die vier Anlageträger nicht mehr unter den zehn meisteingesetzten Bullen der Zucht. Dennoch sind deren männliche Nachkommen zum Teil in der aktuellen (April 2017) Töchter-basierten Zuchtwertschätzung der durch künstliche Besamung (KB) aktiven Holstein-Rotbunt Bullen (nach Gesamtzuchtwert (RZG) sortiert) gelistet (Vereinigte Informationssysteme Tierhaltung, 2017b). Einer der drei aktuell gelisteten Nachkommen des Bullen \#870 wurde bereits mittels Genotypisierung als Anlageträger identifiziert. Dieser Bulle rangiert unter den Top 20 der Zuchtwertschätzung. Auch sein Vater, Bulle \#870, rangiert in der aktuellen (April 2017) Töchter-basierten Zuchtwertschätzung der Holstein-Rotbunt Bullen mit mindestens 500 Töchtern in Deutschland unter den Top 10 (Vereinigte Informationssysteme Tierhaltung, 2017a). Zudem müsste statistisch gesehen jede vierte Tochter (vgl. Anhang Tabelle A1) der heterozygot typisierten Bullen eine Anlageträgerin für das Merkmal sein. Kommt es zur Anpaarung zweier Anlageträger würde wiederum statistisch gesehen jeder vierte Nachkomme homozygot und damit von kongenitaler Katarakt betroffen sein. Da sowohl männliche als auch weibliche phänotypisch unauffällige Anlageträger in der Population vorhanden sind, ist davon auszugehen, dass es auch weiterhin zum Auftreten von Fällen kongenitaler Katarakte kommen wird.

Katarakte sind weltweit die häufigste Ursache für Blindheit beim Menschen (Pascolini und Mariotti, 2012). Für Mensch und Maus sind bereits über 290 Gene und an die 20 Loci beschrieben, die mit dem Auftreten von Katarakt assoziiert wurden (Shiels et al., 2010, 2016). Shiels und Hejtmancik (2013) gaben an, dass etwa $10 \%$ der kartierten humanen Kataraktmutationen keiner kausalen Mutation in einem Gen zugeordnet werden konnten. Auch deshalb ist die kontinuierliche Identifikation von neuen, bisher nicht assoziierten Kandidatengenen für die humane Kataraktforschung wichtig. Hierbei kann das Rind als Tiermodell dienen. Speziell im Fall von CPAMD8 wäre das Rind im Gegensatz zur Maus ein geeignetes Tiermodell, da kein murines CPAMD8-Ortholog vorliegt. Ein Einsatz von Knockout-Mäusen wäre dementsprechend nicht möglich, um die pathologischen Auswirkungen der identifizierten Mutation näher zu untersuchen 
bzw. zu bestätigen. Die Proteinsequenzen von CPAMD8 von Mensch und Rind sind hingegen nach NCBI-Datenbank (https://www.ncbi.nIm.nih.gov) bis zu $86 \%$ identisch und lassen mit hoher Wahrscheinlichkeit auf eine artübergreifende vergleichbare funktionelle Rolle schließen.

Wie in Kapitel 2 der vorliegenden Studie bereits diskutiert, ist die biologische Funktion von CPAMD8 weiterhin ungeklärt. Auch Cheong et al. (2016), welche mehrere Mutationen im humanen CPAMD8-Gen identifizierten, konnten den exakten biologischen Wirkungsmechanismus des Proteins bezüglich der Entstehung einer Katarakt bzw. der Dysgenesie des vorderen Augensegments nicht darlegen. Zudem bleibt die genaue Lokalisation von CPAMD8 in der Linse unbekannt. Ebenfalls ist bisher wenig über mögliche Interaktionspartner von CPAMD8 bekannt. In Bezug auf die Aufklärung der Funktion des Proteins könnte dies allerdings einen entscheidenden Hinweis geben. In der STRING-Datenbank (Szklarczyk et al., 2015, http://string-db.org) sind für das humane CPAMD8 mehrere Interaktionspartner gelistet. Eine graphische Darstellung dieser ist in Abbildung A1 im Anhang dargestellt. Die angezeigten Interaktionen von CPAMD8 mit den Proteinen GUCY1A2, NTNG1, SH3TC1, STARD8, ZNF569 beruhen allesamt auf einer Co-Nennung in der Publikation von Yi et al. (2011). Für die Gene CPAMD8, GUCY1A2, NTNG1, SH3TC1, STARD8 und ZNF569 konnte dabei eine Darmkrebs-spezifische DNA-Methylierung nachgewiesen werden. Eine direkte Interaktion der oben genannten Proteine wurde indes nicht festgestellt. Die in Abbildung A1 im Anhang dargestellte Interaktion von CPAMD8 und FURIN bezieht sich auf das im CPAMD8 identifizierte „Furin cleavage motif“. Dieses konservierte Bindemotiv ist auch bei weiteren Mitgliedern der C3/A2M-Proteinfamilie, wie C3, C4 und C5, vorhanden (Li et al., 2004; Cheong et al., 2016). Die angezeigte Interaktion von CPAMD8 und ZNF777 (Anhang Abbildung A1) basiert auf einer Co-Nennung in einer Publikation von 1999. In dieser wurden cDNA Klone bisher unbekannter humaner Gene identifiziert (Nagase et al., 1999). In Datenbanken wie NCBI ist für CPAMD8 (https://www.ncbi.nlm.nih.gov/gene/?term=CPAMD8) u.a. der Alternativname „VIP“ gelistet. Die aufgeführten Interaktionen von CPAMD8 mit den Proteinen ADCYAP1, DPP4 und SCTR (Anhang Abbildung A1) basieren allesamt auf Publikationen, bei denen sich auf das „vasoactive intestinal peptide“ (VIP) bezogen wird, weshalb die angezeigten Interaktionen in diesen Fällen irreführend sind (Felley et al., 1992; Lambeir et al., 2001). 
Auch die für das Rind gelisteten Interaktionspartner von CPAMD8 (Anhang Abbildung A2) beziehen sich lediglich auf Co-Nennungen in Publikationen (Fullwood et al., 2011; Yi et al., 2011).

Festzuhalten bleibt ferner, dass in der hier beschriebenen Studie zur Kataraktentstehung beim Rind humanspezifische Antikörper verwendet wurden (vgl. Kapitel 2, S2 Table). Die Spezifität der humanen Antikörper wurde mittels eines in vitro exprimierten rekombinaten bovinen CPAMD8 Epitops im Western Blot getestet (vgl. Kapitel 2, S1 Appendix und S2 Fig). Dennoch könnte der Einsatz eines rinderspezifischen Antikörpers gegen CPAMD8 in weiterführenden Studien die Möglichkeit offenbaren das Protein in bovinen Proben besser nachzuweisen. Diesbezüglich kann auch die auftragsmäßige Produktion eines rinderspezifischen Antikörpers eine Option sein.

Im zweiten Teil der vorliegenden Studie wurden die Ausprägungsformen und die genetische Grundlage der iridalen Hypopigmentierung beim HF Rind näher untersucht. In Bezug auf den Phänotyp der Anomalie kann als zentrales Ergebnis konstatiert werden, dass bei betroffenen Tieren sowohl neurologisch als auch ophthalmologisch keine weiteren Abnormitäten neben der Irishypopigmentierung festgestellt werden konnten. Diese Beobachtung ist von wesentlicher Bedeutung, da die Pigmentierung der humanen Iris beim Auftreten von Okulokutanem Albinismus, Hermansky-Pudlak-, Horner- und Waardenburg-Syndrom sowie der Fuchs Heterochromen Iridozyklitis oftmals verändert erscheint (Anderson et al., 2008) (vgl. dazu auch Kapitel 1.3.2).

Nach heutigem Wissensstand ist der Haupteffekt der hier beschriebenen iridalen Hypopigmentierung beim Rind lediglich von kosmetischer Relevanz. Allerdings wurden potentielle Langzeiteffekte bisher nicht erfasst, da die zwei untersuchten Tiere mit fünf bzw. sieben Monaten zum Zeitpunkt der Befundung noch relativ jung waren. Um eine endgültige Aussage über die Auswirkungen der Hypopigmentierung bezüglich des Auftretens potentieller sekundärer Augenerkrankungen treffen zu können, müssten darüber hinaus ältere betroffene Tiere untersucht werden. Die Hauptfunktion der Iris besteht in der Regulation des Lichteinfalls in das Augeninnere. Der größte Anteil tritt dabei durch die Pupille ein. Allerdings dringt auch durch die pigmentierte Iris selber Licht in das Innere des Auges. So wurde bereits nachgewiesen, dass es Unterschiede in der 
Lichttransmission zwischen heller und dunkler kolorierten Iriden gibt (Watts, 1971). Auf Basis dieser Erkenntnis sollte auch ein Vergleich zwischen betroffenen Tieren aus Weidehaltung und Stallhaltung in Betracht gezogen werden, da Rinder in Weidehaltung tendenziell einer erhöhten Lichtexposition ausgesetzt sind. Dennoch ist festzuhalten, dass es zum jetzigen Zeitpunkt bei den untersuchten HF Rindern mit Irishypopigmentierung keinen Hinweis auf die Entwicklung weiterer okularer Anomalien gibt.

Hof (2015) konnte bei sieben von 925 untersuchten Rindern eine Heterochromia iridis partialis feststellen, wobei die Veränderungen der Irisfarbe sowohl uni- als auch bilateral und in Kombination mit weiteren Augenveränderungen wie Katarakt, Blindheit und Reste hinterer Synechien auftraten. Weitere Kennzahlen zum Auftreten von Irishypopigmentierung beim Rind sind nicht existent. Allerdings wurden bereits während der hier beschriebenen Studie drei weitere Fälle mit makroskopisch identischer Ausprägung einer iridalen Hypopigmentierung gemeldet. Aufgrund dieser Zufallsbefunde kann von weiteren betroffenen Tieren innerhalb der deutschen HF Population ausgegangen werden. Neben den betroffenen Rindern der Rasse HF wurden auch zwei Tiere aus einer Kreuzung von Rotvieh und Fleckvieh erfasst, die Anzeichen einer Irishypopigmentierung zeigten. Eine histologische Untersuchung zur Lokalisation der Pigmentreduktion wurde nicht durchgeführt, sodass eine identische phänotypische Ausprägung der Hypopigmentierung bisher nur vermutet werden kann.

Genetisch wurde das Auftreten von Irishypopigmentierung mit dem Abschnitt von 57,3-65,3 Mb auf dem bovinen Chromosom 8 (BTA8) assoziiert. Dieser Abschnitt umfasst nach NCBI-Datenbank insgesamt 151 Gene (UMD3.1.1). Der Marker mit dem höchsten $-\log _{10}(p)$-Wert von 9,17 (BTB-00352779) liegt im intronischen Bereich von RNF38 (ring finger protein 38). Wie bereits in Kapitel 3 diskutiert, konnten die in der Region lokalisierten Gene bisher nicht direkt mit Pigmentierungsprozessen in Verbindung gebracht werden. Eisenberg et al. (2002) vermuten jedoch basierend auf in silico-Analysen von RNF38 ESTs (Expressed Sequence Tags) eine Transkription des Gens in der Retina und in Melanozyten. Ungefähr 356 kb upstream von RNF38 liegt PAX5 (paired box 5). PAX5 wurde bereits in einer Studie über die Fellfarbenausprägung bei Rindern mit dem Anteil schwarzer Fellfärbung assoziiert (Hayes et al., 2010). Ein direkter Nachweis über die Beteiligung von PAX5 an Pigmentierungsprozessen erfolgte allerdings 
bisher nicht. Ein weiteres Mitglied der PAX-Familie, PAX6, ist hinreichend für die Beteiligung an okularen Entwicklungsprozessen bekannt (Graw, 1996; Shaham et al., 2012). Mutationen im humanen PAX6 führen u.a. zu Aniridie und Katarakt (Prosser und van Heyningen, 1998). PAX3 gehört zur Gruppe der an der Melaninsynthese beteiligten Transkriptionsfaktoren (Kubic et al., 2008). Mutationen im humanen PAX3-Gen sind mit dem Auftreten vom Waardenburg-Syndrom Typ 1 assoziiert (Tassabehji et al., 1995; Wildhardt et al., 2013), welches beim Menschen durch sensoneuralen Hörverlust und Pigmentierungsstörungen von Iris (Heterochromia iridis), Haut und Haaren sowie Dystopia canthorum gekennzeichnet ist (Spritz et al., 2003; Eigelshoven et al., 2009; Wildhardt et al., 2013). Zudem wurde bereits eine Interaktion zwischen PAX3 bzw. PAX6 und dem Transkriptionsfaktor MITF nachgewiesen, welcher an okularen Entwicklungsund Pigmentierungsprozessen beteiligt ist (Watanabe et al., 1998; Planque et al., 2001). Die oben genannten Aspekte und die Tatsache, dass die Proteine der PAX-Familie strukturelle Ähnlichkeiten aufweisen (Dahl et al., 1997; Blake und Ziman, 2014), unterstützen die Hypothese, dass PAX5 an der Entwicklung einer iridalen Hypopigmentierung relevant beteiligt ist. Um die genetische Grundlage der iridalen Hypopigmentierung näher zu beleuchten, scheint daher eine Analyse von PAX5 und auch RNF38 durchaus sinnvoll. Zudem wäre eine weitere Analyse der genetischen Determination der iridalen Hypopigmentierung unter anderem durch eine genomweite Re-Sequenzierung von betroffenen Tieren und deren Eltern möglich. 
Schlussfolgerungen und Ausblick

Aus den Ergebnissen der beiden Teilprojekte zu den Augenerkrankungen (kongenitale Katarakte und iridale Hypopigmentierung) beim HF Rind können die folgenden Interpretationen und Schlussfolgerungen für nachfolgende Untersuchungen abgeleitet werden:

Studie 1: Morgagnian cataract resulting from a naturally occurring nonsense mutation elucidates a role of CPAMD8 in mammalian lens development

- Die bei den untersuchten HF Rindern beobachteten kongenitalen Linsentrübungen ließen sich als Cataracta matura klassifizieren. Im Verlauf des Lebens kam es zum Teil zur Entwicklung von Morgagni-Kugeln und dementsprechend zu einer Cataracta hypermatura. Durch kontinuierlich ablaufende Auflösungsprozesse der Linse und den daraus resultierenden entzündlichen Reaktionen im Auge kam es zur Ausprägung weiterer nicht kongenitaler Augenerkrankungen.

- Der Erbgang der hier untersuchten kongenitalen Linsentrübung bei HF Rindern wurde als autosomal rezessiv definiert.

- Eine mit der Erkrankung assoziierte Mutation konnte im CPAMD8-Gen an Position g.5995966C>T (UMD_3.1) lokalisiert werden. Die Missense-Mutation (p.Glu74*) in Exon 1 des Gens führt zu einem vorzeitigen Stopcodon und damit zum Verlust des korrespondierenden Proteins bei homozygot betroffenen Rindern.

- Durch die Identifikation der Mutation g.5995966C >T ist nun die Genotypisierung potentieller Anlageträger in der HF Population möglich.

- Eine RNA-Expression von CPAMD8 konnte in fetalem, adultem und kataraktogenem Linsenmaterial nachgewiesen werden.

- Mittels Immunhistochemie konnte CPAMD8 im Ziliarkörperepithel gesunder Kontrolltiere, nicht aber in der Linse verifiziert werden. Bei Tieren mit 
kongenitaler Katarakt konnte keinerlei Proteinexpression von CPAMD8 nachgewiesen werden.

- Die biologische Wirkungsweise des CPAMD8 Proteins bleibt unbekannt. In weiteren Studien könnten z.B. über die Identifikation potentieller Interaktionspartner Rückschlüsse auf die Funktion von CPAMD8 gezogen werden.

Studie 2: A genome-wide association study reveals a locus for bilateral iridal hypopigmentation in Holstein Friesian cattle

- Der Effekt der iridalen Hypopigmentierung ist vorrangig kosmetisch, wobei Langzeiteffekte der Anomalie bisher nicht untersucht wurden.

- Die Hypopigmentierung beschränkt sich auf die vordere Grenzschicht und das Irisstroma.

- Genetisch ist die Irishypopigmentierung mit der Region von 57,3-65,3 Mb auf dem bovinen Chromosom 8 assoziiert, in der keine eindeutig positionellfunktionellen Kandidatengene lokalisiert sind.

- Um die genetische Determination der Irishypopigmentierung weiter aufzuklären, erscheint unter anderem eine genomweite Re-Sequenzierung von betroffenen Rindern und deren Eltern sinnvoll. 


\section{Literaturverzeichnis}

Anderson, M.G., Hawes, N.L., Trantow, C.M., Chang, B. und John, S.W. (2008). Iris Phenotypes and Pigment Dispersion Caused by Genes Influencing Pigmentation. Pigment Cell Melanoma Res 21, 565-578.

Arbeitsgemeinschaft deutscher Rinderzüchter (ADR) (2004): Rinderproduktion in Deutschland 2003. Zucht, Besamung, Leistungsprüfung. Arbeitsgemeinschaft deutscher Rinderzüchter e.V., Bonn 2004.

Arbeitsgemeinschaft deutscher Rinderzüchter (ADR) (2005): Rinderproduktion in Deutschland 2004. Zucht, Besamung, Leistungsprüfung. Arbeitsgemeinschaft deutscher Rinderzüchter e.V., Bonn 2005.

Arbeitsgemeinschaft deutscher Rinderzüchter (ADR) (2006): Rinderproduktion in Deutschland 2005. Zucht, Besamung, Leistungsprüfung. Arbeitsgemeinschaft deutscher Rinderzüchter e.V., Bonn 2006.

Arbeitsgemeinschaft deutscher Rinderzüchter (ADR) (2007): Rinderproduktion in Deutschland 2006. Zucht, Besamung, Leistungsprüfung. Arbeitsgemeinschaft deutscher Rinderzüchter e.V., Bonn 2007.

Arbeitsgemeinschaft deutscher Rinderzüchter (ADR) (2008): Rinderproduktion in Deutschland 2007. Zucht, Besamung, Leistungsprüfung. Arbeitsgemeinschaft deutscher Rinderzüchter e.V., Bonn 2008.

Arbeitsgemeinschaft deutscher Rinderzüchter (ADR) (2009): Rinderproduktion in Deutschland 2008. Zucht, Besamung, Leistungsprüfung. Arbeitsgemeinschaft deutscher Rinderzüchter e.V., Bonn 2009.

Arbeitsgemeinschaft deutscher Rinderzüchter (ADR) (2010): Rinderproduktion in Deutschland 2009. Zucht, Besamung, Leistungsprüfung. Arbeitsgemeinschaft deutscher Rinderzüchter e.V., Bonn 2010.

Arbeitsgemeinschaft deutscher Rinderzüchter (ADR) (2011): Rinderproduktion in Deutschland 2010. Zucht, Besamung, Leistungsprüfung. Arbeitsgemeinschaft deutscher Rinderzüchter e.V., Bonn 2011.

Arbeitsgemeinschaft deutscher Rinderzüchter (ADR) (2012). Die am häufigsten eingesetzten Bullen 2011. http://www.adr-web.de/meldungen/die-amhaeufisten-eingesetzten-bullen-2011.html?highlight=bulen+2011\& (aufgerufen am 2017/04/11).

Arbeitsgemeinschaft deutscher Rinderzüchter (ADR) (2013). Die am häufigsten eingesetzten Bullen 2012. http://www.adr-web.de/meldungen/die-amhaeufigsten-eingesetzten-bullen-2012.html?highlight=bulen+2012\& (aufgerufen am 2017/04/12). 
Blake, J.A. und Ziman, M.R. (2014). Pax Genes: Regulators of Lineage Specification and Progenitor Cell Maintenance. Development 141, 737-751.

Charlier, C., Agerholm, J.S., Coppieters, W., Karlskov-Mortensen, P., Li, W., de Jong, G., Fasquelle, C., Karim, L., Cirera, S., Cambisano, N., Ahariz, N., Mullaart, E., Georges, M. und Fredholm, M. (2012). A Deletion in the Bovine FANCI Gene Compromises Fertility by Causing Fetal Death and Brachyspina. PLoS One 7, e43085.

Cheong, S.S., Hentschel, L., Davidson, A.E., Gerrelli, D., Davie, R., Rizzo, R., Pontikos, N., Plagnol, V., Moore, A.T., Sowden, J.C., Michaelides, M., Snead, M., Tuft, S.J. und Hardcastle, A.J. (2016). Mutations in CPAMD8 Cause a Unique Form of Autosomal-Recessive Anterior Segment Dysgenesis. Am J Hum Genet 99, 13381352.

Dahl, E., Koseki, H. und Balling, R. (1997). Pax Genes and Organogenesis. Bioessays 19, 755-765.

Deutscher Holstein Verband e.V., D. (2013). Zuchtziel: Deutsche Holsteins. http://www.holstein-dhv.de/aktuelles/deutsche-holsteins-mit-neuem-zuchtziel .html?highlight=zuchtziel\& (aufgerufen am 02.03.2017).

Eigelshoven, S., Kameda, G., Kortüm, A.K., Hübsch, S., Angerstein, W., Singh, P., Vöhringer, R., Goecke, T., Mayatepek, E., Ruzicka, T., Wildhardt, G., Meissner, T. und Kruse, R. (2009). Waardenburg Syndrome Type I with Heterochromia Iridis and Circumscribed Hypopigmentation of the Skin. Pediatr Dermatol 26, 759-761.

Eisenberg, I., Hochner, H., Levi, T., Yelin, R., Kahan, T. und Mitrani-Rosenbaum, S. (2002). Cloning and Characterization of a Novel Human Gene RNF38 Encoding a Conserved Putative Protein with a Ring Finger Domain. Biochem Biophys Res Commun 294, 1169-1176.

Felley, C.P., Qian, J.M., Mantey, S., Pradhan, T. und Jensen, R.T. (1992). Chief Cells Possess a Receptor with High Affinity for PACAP and VIP That Stimulates Pepsinogen Release. Am J Physiol 263, G901-907.

Fritz, S., Capitan, A., Djari, A., Rodriguez, S.C., Barbat, A., Baur, A., Grohs, C., Weiss, B., Boussaha, M., Esquerre, D., Klopp, C., Rocha, D. und Boichard, D. (2013). Detection of Haplotypes Associated with Prenatal Death in Dairy Cattle and Identification of Deleterious Mutations in GART, SHBG and SLC37A2. PLoS One 8, e65550.

Fullwood, M.J., Lee, J., Lin, L., Li, G., Huss, M., Ng, P., Sung, W.K. und Shenolikar, S. (2011). Next-Generation Sequencing of Apoptotic DNA Breakpoints Reveals Association with Actively Transcribed Genes and Gene Translocations. PLoS One 6, e26054. 
Graw, J. (1996). Genetic Aspects of Embryonic Eye Development in Vertebrates. Dev Genet 18, 181-197.

Hayes, B.J., Pryce, J., Chamberlain, A.J., Bowman, P.J. und Goddard, M.E. (2010). Genetic Architecture of Complex Traits and Accuracy of Genomic Prediction: Coat Colour, Milk-Fat Percentage, and Type in Holstein Cattle as Contrasting Model Traits. PLoS Genet 6, e1001139.

Hof, K. A. (2015): Klinische, pathomorphologische und sonographische Untersuchungen am Rinderauge. Dissertation Freie Universität Berlin. Abrufbar unter: http://www.diss.fu-berlin.de/diss/receive/FUDISS_thesis_000000101076.

Koenig, S. und Simianer, H. (2006). Approaches to the Management of Inbreeding and Relationship in the German Holstein Dairy Cattle Population. Livest Sci 103, 4053.

Kubic, J. D., Young, K. P., Plummer, R. S., Ludvik, A. E. und Lang, D. (2008). Pigmentation PAX-ways: The role of Pax3 in melanogenesis, melanocyte stem cell maintenance, and disease. Pigment Cell \& Melanoma Research, 21 (6), 627-645.

Lambeir, A.M., Durinx, C., Proost, P., Van Damme, J., Scharpe, S. und De Meester, I. (2001). Kinetic Study of the Processing by Dipeptidyl-Peptidase IV/CD26 of Neuropeptides Involved in Pancreatic Insulin Secretion. FEBS letters 507, 327330.

Li, Z.F., Wu, X.H. und Engvall, E. (2004). Identification and Characterization of CPAMD8, a Novel Member of the Complement 3/alpha2-Macroglobulin Family with a CTerminal Kazal Domain. Genomics 83, 1083-1093.

McClure, M.C., Bickhart, D., Null, D., Vanraden, P., Xu, L., Wiggans, G., Liu, G., Schroeder, S., Glasscock, J., Armstrong, J., Cole, J.B., Van Tassell, C.P. und Sonstegard, T.S. (2014). Bovine Exome Sequence Analysis and Targeted SNP Genotyping of Recessive Fertility Defects $\mathrm{BH} 1, \mathrm{HH} 2$, and $\mathrm{HH} 3$ Reveal a Putative Causative Mutation in SMC2 for HH3. PLoS One 9, e92769.

Menzi, F., Besuchet-Schmutz, N., Fragnière, M., Hofstetter, S., Jagannathan, V., Mock, T., Raemy, A., Studer, E., Mehinagic, K., Regenscheit, N., Meylan, M., SchmitzHsu, F. und Drogemuller, C. (2016). A Transposable Element Insertion in APOB Causes Cholesterol Deficiency in Holstein Cattle. Anim Genet 47, 253-257.

Nagase, T., Ishikawa, K., Kikuno, R., Hirosawa, M., Nomura, N. und Ohara, O. (1999). Prediction of the Coding Sequences of Unidentified Human Genes. XV. The Complete Sequences of 100 New cDNA Clones from Brain Which Code for Large Proteins in Vitro. DNA Res 6, 337-345.

Pascolini, D. und Mariotti, S.P. (2012). Global Estimates of Visual Impairment: 2010. Br J Ophthalmol 96, 614-618. 
Planque, N., Leconte, L., Coquelle, F.M., Martin, P. und Saule, S. (2001). Specific Pax6/Microphthalmia Transcription Factor Interactions Involve Their DNA-Binding Domains and Inhibit Transcriptional Properties of Both Proteins. J Biol Chem 276, 29330-29337.

Prosser, J. und van Heyningen, V. (1998). Pax6 Mutations Reviewed. Hum Mutat 11, 93108.

Schütz, E., Wehrhahn, C., Wanjek, M., Bortfeld, R., Wemheuer, W.E., Beck, J. und Brenig, B. (2016). The Holstein Friesian Lethal Haplotype 5 (HH5) Results from a Complete Deletion of TFB1M and Cholesterol Deficiency (CDH) from an ERV(LTR) Insertion into the Coding Region of APOB. PLoS One 11, e0154602.

Shaham, O., Menuchin, Y., Farhy, C. und Ashery-Padan, R. (2012). PAX6: A Multi-Level Regulator of Ocular Development. Prog Retin Eye Res 31, 351-376.

Shiels, A. und Hejtmancik, J.F. (2013). Genetics of Human Cataract. Clin Genet 84, $120-$ 127.

Shiels, A., Bennett, T.M. und Hejtmancik, J.F. (2010). Cat-Map: Putting Cataract on the Map. Mol Vis 16, 2007-2015.

Shiels, A., Mackay, D. und Bennett, T. (2016). Cat-Map. http://cat-map.wustl.edu (aufgerufen am 2016/12/01).

Shuster, D.E., Kehrli, M.E., Ackermann, M.R. und Gilbert, R.O. (1992). Identification and Prevalence of a Genetic Defect That Causes Leukocyte Adhesion Deficiency in Holstein Cattle. Proc Natl Acad Sci USA. 89, 9225-9229.

Spritz, R.A., Chiang, P.W., Oiso, N. und Alkhateeb, A. (2003). Human and Mouse Disorders of Pigmentation. Curr Opin Genet Dev 13, 284-289.

Szklarczyk, D., Franceschini, A., Wyder, S., Forslund, K., Heller, D., Huerta-Cepas, J., Simonovic, M., Roth, A., Santos, A., Tsafou, K.P., Kuhn, M., Bork, P., Jensen, L.J. und von Mering, C. (2015). String v10: Protein-Protein Interaction Networks, Integrated over the Tree of Life. Nucleic Acids Res 43, D447-452.

Tassabehji, M., Newton, V.E., Liu, X.Z., Brady, A., Donnai, D., Krajewska-Walasek, M., Murday, V., Norman, A., Obersztyn, E., Reardon, W., Rice, J.C., Trembath, R., Wieacker, P., Whiteford, M., Winter, R. und Read, A. P. (1995). The Mutational Spectrum in Waardenburg Syndrome. Hum Mol Genet 4, 2131-2137.

Thomsen, B., Horn, P., Panitz, F., Bendixen, E., Petersen, A.H., Holm, L.E., Nielsen, V.H., Agerholm, J.S., Arnbjerg, J. und Bendixen, C. (2006). A Missense Mutation in the Bovine SLC35A3 Gene, Encoding a UDP-N-Acetylglucosamine Transporter, Causes Complex Vertebral Malformation. Genome Res 16, 97-105. 
Vereinigte Informationssysteme Tierhaltung, V. (2017a). Relativzuchtwerte (Rangierung Rzg) Töchter Basiert, KB Bullen Mit mind. 500 Deu Töchtern. http://www.vit.de/fileadmin/user_upload/vit-fuers-rind/zuchtwertschaetzung/ milchrinder-zws-online/RotBunt_RZG_WiedereinsatzBullen.pdf (aufgerufen am 2017/04/18).

Vereinigte Informationssysteme Tierhaltung, V. (2017b). Relativzuchtwerte (Rangierung Rzg) Töchter Basiert, nur aktive KB Bullen. http://www.vit.de/fileadmin/user_upload/vit-fuers-rind/zuchtwertschaetzung/ milchrinder-zws-online/RotBunt_RZG_aktiveBullen.pdf (aufgerufen am 2017/04/13).

Watanabe, A., Takeda, K., Ploplis, B. und Tachibana, M. (1998). Epistatic Relationship between Waardenburg Syndrome Genes MITF and PAX3. Nature Genetics 18, 283-286.

Watts, G.K. (1971). Retinal Hazards During Laser Irradiation of the Iris. Br J Ophthalmol $55,60-67$.

Wildhardt, G., Zirn, B., Graul-Neumann, L.M., Wechtenbruch, J., Suckfüll, M., Buske, A., Bohring, A., Kubisch, C., Vogt, S., Strobl-Wildemann, G., Greally, M., Bartsch, O. und Steinberger, D. (2013). Spectrum of Novel Mutations Found in Waardenburg Syndrome Types 1 and 2: Implications for Molecular Genetic Diagnostics. BMJ open 3, e001917.

Yi, J.M., Dhir, M., Van Neste, L., Downing, S.R., Jeschke, J., Glockner, S.C., de Freitas Calmon, M., Hooker, C.M., Funes, J.M., Boshoff, C., Smits, K.M., van Engeland, M., Weijenberg, M.P., lacobuzio-Donahue, C.A., Herman, J.G., Schuebel, K.E., Baylin, S.B. und Ahuja, N. (2011). Genomic and Epigenomic Integration Identifies a Prognostic Signature in Colon Cancer. Clin Cancer Res 17, 1535-1545. 


\section{Anhang}

\section{Zusätzliche Tabellen und Abbildungen}

Anhang Tabelle A1: Übersicht über die Besamungszahlen der Bullen mit den internen Nummern \#870, \#977, \#890 und \#053 (Arbeitsgemeinschaft deutscher Rinderzüchter (ADR), 2004-2013).

\begin{tabular}{|c|c|c|c|c|}
\hline Jahr & $\mathbf{\# 8 7 0}^{\mathbf{1}}$ & $\mathbf{\# 9 7 7}^{\mathbf{1}}$ & $\mathbf{\# 8 9 0}^{\mathbf{1}}$ & $\mathbf{\# 0 5 3}^{\mathbf{1}}$ \\
\hline 2003 & & 17542 & & \\
\hline 2004 & & 7526 & 28618 & \\
\hline 2005 & & & 20679 & 17122 \\
\hline 2006 & & & 13895 & 19240 \\
\hline 2007 & & & 9965 & 11114 \\
\hline 2008 & 15496 & & 6706 & \\
\hline 2009 & 20235 & & & \\
\hline 2010 & 11172 & & & \\
\hline 2011 & 14654 & & & \\
\hline 2012 & 9040 & & & \\
\hline $\begin{array}{c}\text { Töchter in Milch } \\
\text { Deutschland }\end{array}$ & 16282 & 5616 & 19457 & 13797 \\
\hline
\end{tabular}

${ }^{1}$ Sind für das jeweilige Jahr keine Werte eingetragen, so befanden sich die Vererber nicht unter den zehn meisteingesetzten Bullen des jeweiligen Jahres. Die Gesamtzahl an Töchtern in Milch in Deutschland für die vier Bullen stammt aus der Interbull-Datenbank des VIT (https://service.vit.de/interbull/, Stand 11. April 2017). 


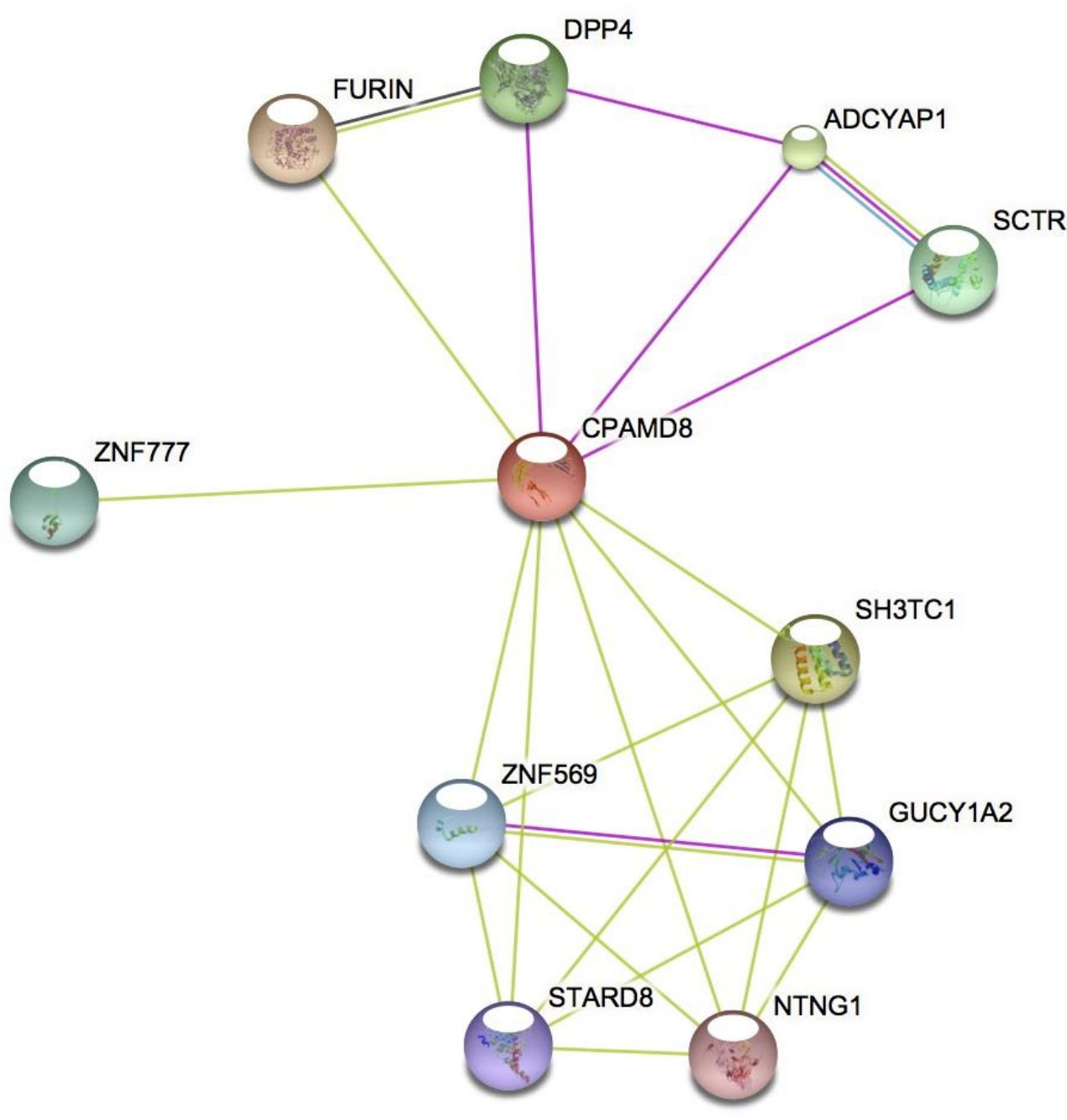

Anhang Abbildung A1: In der STRING-Datenbank angegebene Interaktionspartner des humanen CPAMD8 (STRING-Datenbank, http://bit.ly/2pcGOjc, aufgerufen am 03.05.2017).

Pinke Linien symbolisieren Interaktionen zwischen zwei Proteinen basierend auf experimentellen Daten. Grüne Linien zeigen Interaktionen von Proteinen basierend auf Textmining-Analysen an. Schwarze Linien zeigen Co-Expressionen an, hellblaue Linien hingeben geben Homologien zwischen Proteinen an. 


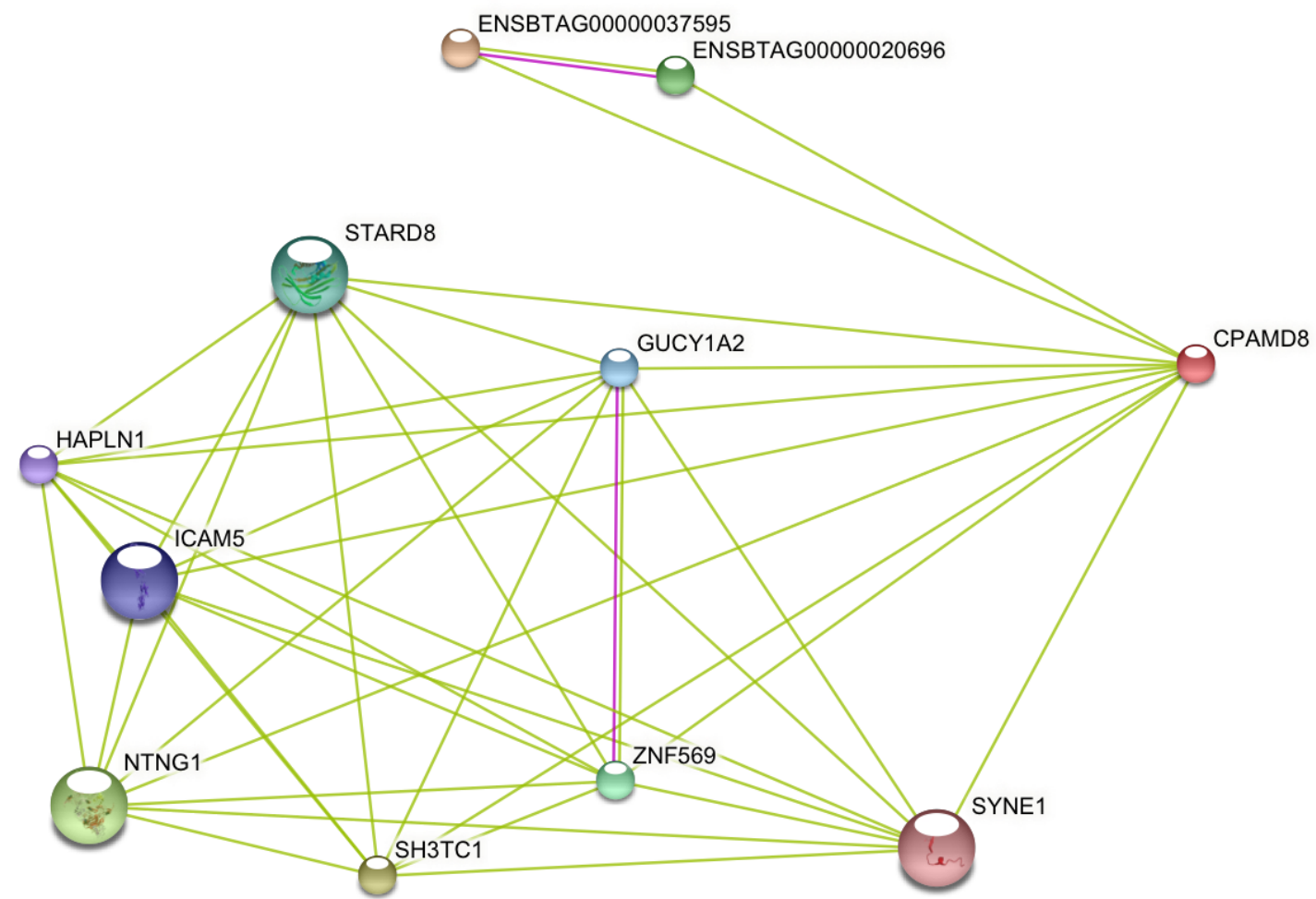

Anhang Abbildung A2: In der STRING-Datenbank angegebene Interaktionspartner des bovinen CPAMD8 (STRING-Datenbank, http://bit.ly/2pcM2LL, aufgerufen am 03.05.2017).

Pinke Linien symbolisieren Interaktionen zwischen zwei Proteinen basierend auf experimentellen Daten. Grüne Linien zeigen Interaktionen von Proteinen basierend auf Textmining-Analysen an. 


\section{Danksagung}

An dieser Stelle möchte ich mich ganz herzlich bei allen bedanken, die mich bei der Anfertigung dieser Arbeit so tatkräftig unterstützt haben.

Mein Dank gilt Prof. Prof. h.c. Dr. Dr. Bertram Brenig für die Überlassung des Themas, die Betreuung und Unterstützung bei der Bearbeitung der Projekte und der Anfertigung dieser Arbeit sowie für ein stets offenes Ohr in den vergangenen Jahren. Außerdem möchte ich mich für die Ermöglichung des Auslandsaufenthalts in Australien und die Kursteilnahme am EMBL-EBI in Hinxton ganz besonders bedanken!

Des Weiteren geht mein Dank an Prof. Dr. Ekkehard Schütz für die Übernahme des Korreferats, die vielen fachlichen Hilfestellungen während der vergangenen Jahre und das unermüdliche Voranbringen der Projekte.

Prof. Dr. Hummel möchte ich für die Übernahme des zweiten Korreferats danken.

Ein weiterer Dank gilt Dr. Marc Hirschfeld und Dr. Wiebke Wemheuer für das Korrekturlesen dieser Arbeit.

Bei allen Ko-Autorinnen und -Autoren der zwei Veröffentlichungen möchte ich mich für die gute Zusammenarbeit bedanken.

Ferner gilt mein Dank dem gesamten Team von Chronix Biomedical und im Besonderen Dr. Julia Beck für die Unterstützung bei Fachfragen, Bioinformatik und Labortätigkeiten. An Herrn Dr. Wemheuer geht ein großes Dankeschön für die Unterstützung bei den Pedigreeanalysen, dem Sammeln von Probenmaterial und die zahlreichen Tipps und Ratschläge während der vergangenen Jahre.

Ein sehr großes Dankeschön geht zudem an alle ehemaligen und aktuellen Mitarbeiter der Abteilung Molekularbiologie und molekulare Diagnostik. Ein besonderer Dank gilt dabei Sabrina Pach für die großartige Hilfe bei jeglicher Labortätigkeit. Ein herzliches Dankeschön geht zudem an Reiner Andag. Christin Wehrhahn danke ich besonders für die sehr gute Zusammenarbeit und die Freundschaft, die sich in den letzten Jahren entwickelt hat. Ein großes Dankeschön geht ebenfalls an Dr. Liane Schulz-Streeck für die schöne Zeit während der gemeinsamen Büronutzung.

Auch bedanken möchte ich mich bei den Mitarbeiterinnen des ZMD, Melanie Scharfenstein, Louisa Jüttner und Susann Loos, für die stets freundliche Hilfestellung bei 
all meinen Fragen. Ebenso gilt dem Team der Tierpfleger mit Manfred Vopel und Jürgen Hesse sowie Dirk Teuteberg ein Dankeschön!

All meinen Freunden gilt ein ganz besonderer Dank für das geduldige Zuhören und die vielen Aufmunterungen in den letzten Jahren. Allen voran meinen beiden Freundinnen Christina und Birthe!

Der allergrößte Dank geht jedoch an meine Eltern, Heinz-Gerd und Edith, und meine Schwester Meike. Danke für das stundelange Zuhören und Aufbauen, die Unterstützung in moralischer und finanzieller Hinsicht und das Gefühl ein Zuhause zu haben! Ohne euren Beistand wäre diese Arbeit nicht möglich gewesen!

Dieser Dank geht ebenfalls an meine Großeltern und die weitere Familie. Ein besonderer Dank gilt dabei Heike für ihre unermüdliche Unterstützung.

Manuel danke ich für seine Aufmunterungen, seine Ruhe und einfach alles was so sehr darüber hinaus geht! 


\section{Eidesstattliche Erklärung}

1. Hiermit erkläre ich, dass diese Arbeit weder in gleicher noch in ähnlicher Form bereits anderen Prüfungsbehörden vorgelegen hat.

Weiter erkläre ich, dass ich mich an keiner anderen Hochschule um einen Doktorgrad beworben habe.

Göttingen, den 08. Mai 2017

(Unterschrift)

2. Hiermit erkläre ich eidesstattlich, dass diese Dissertation selbständig und ohne unerlaubte Hilfe angefertigt wurde.

Göttingen, den 08. Mai 2017

(Unterschrift) 